TILDE RODRIGUES FROES

\title{
UTILIZAÇÃO DA ULTRA-SONOGRAFIA EM CÃES COM SUSPEITAS DE NEOPLASIAS DO SISTEMA DIGESTÓRIO (FÍGADO, INTESTINOS E PÂNCREAS)
}




\section{TILDE RODRIGUES FROES}

Utilização da ultra-sonografia em cães com suspeitas de neoplasias do sistema digestório (fígado, intestinos e pâncreas)

Tese apresentada ao Programa de Pósgraduação em Cirurgia Veterinária da Faculdade de Medicina Veterinária e Zootecnia da Universidade de São Paulo para obtenção do título de doutor em Medicina Veterinária

Departamento:

Cirurgia

Área de concentração:

Cirurgia

Orientador:

Prof. Dr. Masao Iwasaki

São Paulo

2004 
Autorizo a reprodução parcial ou total desta obra, para fins acadêmicos, desde que citada a fonte.

DADOS INTERNACIONAIS DE CATALOGAÇÃO-NA-PUBLICAÇÃO

(Biblioteca da Faculdade de Medicina Veterinária e Zootecnia da Universidade de São Paulo)

\begin{tabular}{|c|c|}
\hline $\begin{array}{l}\text { T.1375 } \\
\text { FMVZ }\end{array}$ & $\begin{array}{l}\text { Froes, Tilde Rodrigues } \\
\quad \text { Utilização da ultra-sonografia em cães com suspeitas de } \\
\text { neoplasias do sistema digestório (fígado, intestinos e } \\
\text { pâncreas) / Tilde Rodrigues Froes. - São Paulo : T. R. Froes, } \\
2004 \text {. } \\
\quad 155 \text { f. : il. }\end{array}$ \\
\hline & $\begin{array}{l}\text { Tese (doutorado) - Universidade de São Paulo. Faculdade } \\
\text { de Medicina Veterinária e Zootecnia. Departamento de } \\
\text { Cirurgia, 2004. }\end{array}$ \\
\hline & $\begin{array}{l}\text { Programa de Pós-graduação: Cirurgia. } \\
\text { Área de concentração: Cirurgia. }\end{array}$ \\
\hline & Orientador: Prof. Dr. Massao Iwasaki. \\
\hline & $\begin{array}{lll}\text { 1. Ultrasonografia. } 2 . & \text { Cães. } \\
\text { 4. Sistema digestório. I. Título. } & \end{array}$ \\
\hline
\end{tabular}




\section{UNIVERSIDADE DE SÃO PAULO \\ Faculdade de Medicina Veterinária e Zootecnia \\ Cidade Universitária "Armando de Salles Oliveira" \\ Comissão Bioética \\ CERTIFICADO}

Certificamos que o Projeto intitulado "A contribuição da ultra-sonografia no diagnóstico e na monitorização do câncer da cavidade abdominal nos animais de companhia", Protocolo $\mathrm{n}^{\circ}$ 222/2002, sob a responsabilidade do Prof. Dr. Masao Iwasaki, está de acordo com os princípios éticos de experimentação animal da Comissão de Bioética da Faculdåde de Medicina Veterinária e Zootecnia da Universidade de São Paulo sendo aprovado "ad referendun".

(We certify that the Research "Characterization of ultrasonography abdominal in diagnosis and monitoring in tumor abdominal in cats and dogs" protocol number 222/2002, under the responsability of Prof.Dr. Masao Iwasaki, agree with Ethical Principles in Animal Research adopted by Bioethic Commision of the Faculty of Veterinary Medicine and Zootechny of University of São Paulo and was approved "ad referendun" meeting.)

São Paulo, 13 de novembro de 2002

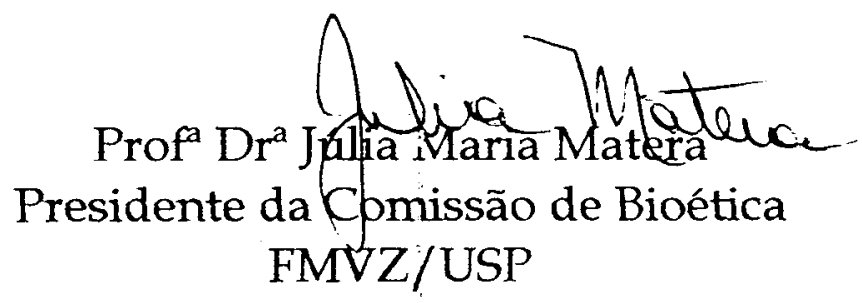




\section{FOLHA DE AVALIAÇÃO}

Nome: FROES, Tilde Rodrigues

Título: Utilização da ultra-sonografia em cães com suspeita de neoplasias do sistema digestório (fígado, intestinos e pâncreas)

Tese apresentada ao Programa de Pósgraduação em Cirurgia Veterinária da Faculdade de Medicina Veterinária e Zootecnia da

Universidade de São Paulo para obtenção do título de doutor em Medicina Veterinária

Data

\section{Banca Examinadora}

Prof. Dr. Instituição:

Assinatura: Julgamento:

Prof. Dr. Instituição:

Assinatura: Julgamento:

Prof. Dr. Instituição:

Assinatura: Julgamento:

Prof. Dr. Instituição:

Assinatura: Julgamento:

Prof. Dr. Instituição:

Assinatura: Julgamento: 
Àquele que é capaz de fazer infinitamente mais do que pedimos ou pensamos, de acordo com o seu poder que atua em nós, a Ele seja a glória. (Efésios 1: 20) 
A todos os proprietários e cães que participaram desta pesquisa 


\section{Agradecimentos}

A vida não é vivida isoladamente. O ser humano, dificilmente realiza algo sozinho, dificilmente concretiza seus sonhos sem companhia. Temos a necessidade de viver com - 0 - outro. Essa comunhão gera compromissos entre pessoas que, embora não formais norteiam nossos afetos e relacionamentos durante períodos de tempo, às vezes por toda a vida, compartilhando idéias e ideais. Assim, este estudo não é só meu. Muitas foram às pessoas que me acompanharam nesta caminhada, que se envolveram na minha idéia e no meu desejo. Das mais diferentes maneiras e cada um a seu modo. A todas as pessoas que estiveram comigo e permaneceram ao meu lado, o meu agradecimento do fundo do coração, e especialmente quero agradecer:

Ao Prof. Dr. Masao Iwasaki , obrigado pela orientação, carinho e confiança.

A Profa e Amiga Janis Regina Messias Gonzalez - praticamente não tenho palavras para expressar a importância que você teve em minha vida pessoal e profissional.

Aos meus pais Geraldo e Mirian sem vocês nada disso seria possível.

Aos meus irmãos Héda e Raphael.

A minha vôzinha Eda.

As Professoras do Departamento de Cirurgia - Júlia M. Matera e Denise T. Fantoni obrigado pelos ensinamentos de convivência hospitalar, ética e amor à profissão.

Aos Professores do Departamento de Patologia - Maria Lúcia Zaidan Magli e José Luiz Guerra, por me receberem tão bem.

A Professora Dra.llka Regina de Oliveira, por proporcionar um grande aprendizado no Serviço de Ultra-sonografia - Doppler - Do INRAD - Instituto de radiologia da Faculdade de Medicina da Universidade de São Paulo.

A Professora Dra. Sílvia Regina Ricci Lucas, por apoiar a pesquisa realizada. 
Aos Professores, Eliana Palaoro Pereira e Hélio Autran de Morais, pelo carinho e conselhos.

Aos Professores do Departamento de Cirurgia - Serviço de Diagnóstico por Imagem Franklin de Almeida Sterman e Ana Carolina Brandão de C. Fonseca, por permitir e apoiar a pesquisa realizada.

A Marieta, pelo cuidado na revisão deste trabalho.

Aos amigos do ultra-som, - Luciane, Renata, Raul, Cláudia e Angélica, além do aprendizado, carinho e risos eram o meu alimento diário.

As Amigas da "CIRU", - Andressa, Patrícia, Sandra, Viviane, Tatiana -, um grande carinho, vários os "CVS" do almoço, que fazia meus dias alegres.., Adoro vocês!

As meninas da "Pato" - Aninha, Luciana e Kátia -

Aos amigos da Radiologia, - Silvana, Benjamin, Reginaldo, Hugo e Kátia, muitíssimo obrigado.

Aos secretários, Ney e Patrícia.

A todos os médicos veterinários, residentes e funcionários do HOVET - Hospital Veterinário da FMVZ-USP.

Aos amigos do Hospital Veterinário PET CARE.

Aos amigos pós-graduandos, - Karina, Denisinha, Valéria, Genilson, Angélica Tartarunas, Pedro, Jun.

As amigas, Carolina e Eliana. 
Aos meninos da informática e manutenção da Faculdade de Medicina Veterinária e Zootecnia da Universidade de São Paulo.

Aos meus amigos felinos - Branca e Jambalaia.

\section{A CAPES}

A FAPESP - pelo apoio financeiro a esta pesquisa

A Deus... 


\section{RESUMO}

FROES, T. R. Utilização da ultra-sonografia em cães com suspeitas de neoplasias do sistema digestório (fígado, intestinos e pâncreas). [The use of ultrasonography in the diagnostic approach of the dogs with suspected of digestive neoplasm (liver, intestines and pancreas)]. 2004. 155 f. (Doutorado em Cirurgia) Faculdade de Medicina Veterinária e Zootecnia, Universidade de São Paulo, São Paulo, 2004.

Os objetivos do presente trabalho foram avaliar a acurácia do exame ultrasonográfico para indicar o órgão abdominal afetado pelo processo neoplásico, determinar as características ultra-sonográficas dos diferentes tipos neoplásicos que acometem o fígado, os intestinos e o pâncreas, bem como analisar a eficácia da ultra-sonografia bidimensional em apontar a malignidade desses processos neoplásicos. A amostra foi constituída por 114 cães com suspeita de processo neoplásico, e a observação compreendeu um período de 12 meses consecutivos. Em 88 desses animais, a presença de neoplasia abdominal foi confirmada. Em 84 $(95,4 \%)$ cães, a origem da massa foi corretamente classificada, em $3(3,5 \%)$ foi erroneamente classificada e em $1(1,1 \%)$, a massa não foi identificada pelo exame sonográfico. Os tipos cito-histológicos diagnosticados no fígado foram: colangiocarcinoma $6(50 \%)$, carcinoma hepatocelular $3(25,1 \%)$, tumor de células mesenquimais-hemangiossarcoma 1(8,3\%), linfoma de pequenas células $1(8,3 \%)$ e cistoadenoma de vias biliares $1(8,3 \%)$. No intestino foram identificados adenocarcinoma $2(25 \%)$, linfoma $2(25 \%)$, leiomiossarcoma $2(25 \%)$, tumor de células mesenquimais $1(12,5 \%)$ e adenoma de cólon $1(12,5 \%)$. No pâncreas foram diagnosticados: adenocarcinoma pancreático 3(75\%) e insulinoma 1(25\%). Com relação à diferenciação entre tumores hepáticos malignos e benignos pela ultrasonografia convencional, 11 casos $(100 \%)$ foram suspeitos de malignidade e confirmados com o padrão-ouro; contudo, parâmetros suspeitos para malignidade também foram observados em um caso de tumor benigno. Ao analisar a ultrasonografia na suspeita de tumores nos segmentos intestinais para a diferenciação entre tumores e processo inflamatório, 8 (100\%) casos suspeitos para processo neoplásico foram confirmados; todavia, parâmetros suspeitos para processos neoplásicos intestinais também foram observados em 3 casos de enterite inflamatória granulomatosa. Ao analisar a ultra-sonografia na suspeita de tumores pancreáticos exócrinos, foi possível identificar e localizar a massa em sua maioria, mas a diferenciação segura entre processo neoplásico e pancreatite crônica não foi possível. Conclui-se que: o exame sonográfico é um bom método de detecção da origem do processo neoplásico abdominal, e que embora não específicos, o achado sonográfico auxilia na determinação da malignidade do processo.

Palavras Chaves: Ultrasonografia. Cães. Neoplasias. Sistema digestório. 


\begin{abstract}
FROES, T. R. The use of ultrasonography in the diagnostic approach of dogs with suspected of digestive neoplasm (liver, intestines and pancreas). [Utilização da ultra-sonografia em cães com suspeita de neoplasias do sistema digestório (fígado, intestinos e pâncreas)]. 2004. 155 f. (Doutorado em Cirurgia) Faculdade de Medicina Veterinária e Zootecnia, Universidade de São Paulo, São Paulo, 2004.
\end{abstract}

The purposes of the present study were to evaluate the diagnostic accuracy of ultrasonography in the assessment of abdominal organs due to neoplastic process, to determine the ultrasonographic findings of each tumor type found in the liver, intestines and pancreas, and thereby study the potential contribution of ultrasonography to distinguish benign from malignant lesions. One hundred and fourteen dogs with suspected neoplastic disease were enrolled in this prospective study during 12 consecutive months. 88 dogs were diagnosed as having abdominal neoplasm. In $84(95,4 \%)$ dogs the affected organ was correctedly identified, in $3(3,5 \%)$ dogs the affected organ was incorrectedly identified and in 1 dog the affected organ wasn't identified. The tumors types in the liver were: cholangiocarcinoma $6(50 \%)$, hepatocellular carcinoma $3(25,1 \%)$, mesenchymal hepatic tumor - hemangiosarcoma $1(8,3 \%)$, small cell lymphoma $1(8,3 \%)$ and bile duct cystadenoma 1(8,3\%). Tumor types in the intestines were: adenocarcinoma $2(25 \%)$, lymphoma in alimentary tract $2(25 \%)$, leiomyosarcoma $2(25 \%)$, mesenchymal cell tumor $1(12,5 \%)$ and colon adenoma $1(12,5 \%)$. In the pancreas were: pancreatic adenocarcinoma $3(75 \%)$ and insulinoma 1(25\%). Considering ultrasonographic findings alone we could predict malignant lesion in 11(100\%) cases, and all cases had proven malignant liver neoplasm. However, one case of benign liver neoplasia was erroneuosly consireded as being malignant. Ultrasonographic findings alone were of important diagnostic value in differentiating intestinal neoplasia from enteritis. Eight (100\%) dogs showing ultrasonographic signs of malignancy were confirmed as having malignant intestinal neoplasia, however, the same signs were seen in 3 cases of inflamatory granulomatous enteritis. Pancreatic masses were correctedly identified, but it was not possible to confidently differentiate between pancreatitis and pancreatic neoplasia. We conclude that use ultrasonography is of great value in determining the affected abdominal organ for neoplasic process, and that the sonography findings although not specific, may help in the assessment of malignancy.

Key words: Ultrasonography. Dogs. Neoplasm. Digestive. 
2 REVISÃO DA LITERATURA 17

2.1 VASCULARIZAÇÃO TUMORAL E UTILIZAÇÃO DA TÉCNICA DOPPLER 21

2.2 NEOPLASIAS ABDOMINAIS EM CÃES $\quad 25$

2.2.1 NEOPLASIAS DE ORIGEM HEPÁTICA E ASPECTOS ULTRA-SONOGRÁFICOS $\mathbf{2 6}$

2.2.2 NEOPLASIAS DE ORIGEM INTESTINAL E ASPECTOS ULTRA-SONOGRÁFICOS $\mathbf{3 9}$

2.2.3 NEOPLASIAS DE ORIGEM PANCREÁTICA E ASPECTOS ULTRA-SONOGRÁFICOS 48

3 MATERIAL E MÉTODO

3.1 MATERIAL

3.2 MÉTODO

4 RESULTADOS

4.1 ORIGEM HEPÁTICA $\quad 69$

4.2 ORIGEM INTESTINAL $\quad 73$

$\begin{array}{ll}4.3 \text { ORIGEM PANCREÁTICA } & \mathbf{7 9}\end{array}$

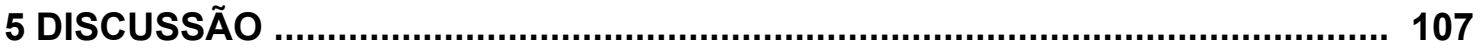

6 CONCLUSÃO

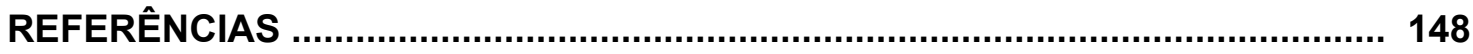




\section{Introdução}




\section{INTRODUÇÃO}

A crescente interação homem-animal e a percepção de que a companhia de cães e gatos contribui para a melhoria da qualidade de vida das pessoas têm contribuído para a conscientização da sociedade quanto aos cuidados que devem ser dispensados à saúde dos animais. Com a melhora do atendimento médico veterinário, os animais começam a atingir idades avançadas, o que aumenta a probabilidade de desenvolverem câncer. Desta forma, e com objetivo de alcançar a cura ou aumentar a sobrevida desses animais, o número de investigações voltadas ao diagnóstico e ao tratamento da moléstia cresceu significativamente nas duas últimas décadas.

As técnicas de diagnóstico por imagem, como a radiologia, a ultra-sonografia, a ultra-sonografia com duplex Doppler e Doppler colorido, a tomografia computadorizada e a ressonância nuclear magnética são subsídios propedêuticos que auxiliam no diagnóstico de tumores abdominais (BLEVINS, 2002). A utilização da ultra-sonografia em medicina veterinária vem se tornando prática comum nos últimos anos, graças ao baixo custo que apresenta em relação a outras modalidades de imagem mais avançadas - como a tomografia computadorizada e a ressonância nuclear magnética -, e à existência de aparelhos desse tipo em grande parte dos hospitais veterinários dos grandes centros.

De acordo com Bragg (1985), a ultra-sonografia não só colabora no diagnóstico, como auxilia no estadiamento, na monitorização e na avaliação de possíveis complicações dos pacientes com tumores abdominais em medicina.

Estudos descrevendo os aspectos sonográficos dos diferentes tipos neoplásicos abdominais em animais foram realizados, mas a maioria deles restringese a análises retrospectivas. Sabe-se ainda que não é possível caracterizar o tipo 
histológico da neoplasia somente pelo exame ultra-sonográfico: a biópsia é imprescindível. Todavia, a ultra-sonografia pode fornecer linhas gerais de orientação na avaliação das lesões tumorais: massas hiperecóicas solitárias hepáticas estão quase sempre associadas ao carcinoma hepatocelular (NYLAND et al., 2002a; VÖRÖS et al.,1991; WHITELEY et al., 1989).

A incidência de neoplasias do sistema digestório é baixa, entretanto, os tumores hepáticos, pancreáticos e intestinais têm grande impacto nos cães, pois, na maioria das vezes o diagnóstico somente é elucidado nos estágios avançados da doença e na presença de metástases (HAMMER; SILKEMMA, 1995; MAGNE, 2000). Estes fatores mostram a importante contribuição no diagnóstico por imagem como tentativa de elucidar o diagnóstico mais precocemente (BLEVINS, 2002).

$\mathrm{Na}$ medicina, investigações tentaram estabelecer características ultrasonográficas em modo bidimensional capazes de diferenciar as lesões benignas neoplásicas, regenerativas ou inflamatórias - daquelas malignas, mas essa diferenciação - baseada somente na ultra-sonografia bidimensional - ainda é difícil (ANDOLF, 1993; BOURNET et al., 1991).

Também em medicina veterinária dois estudos retrospectivos foram realizados com esse intuito: um deles objetivava verificar valores indicativos para a malignidade em nódulos "alvo" no fígado e no baço de cães e gatos (CUCCOVILLO; LAMB, 2002); o outro pretendia estabelecer a diferença entre as neoplasias intestinais e os processos inflamatórios intestinais crônicos por meio da ultrasonografia (PENNINCK et al., 2003). Embora se tratassem de estudos retrospectivos, os resultados obtidos em ambos foram satisfatórios.

Assim como na medicina, a avaliação com o Doppler e agentes de contraste sonográficos poderá contribuir para a investigação de tumores abdominais em 
pequenos animais. Estudos dessa ordem já foram sugeridos na literatura veterinária, mas a eficácia dessas técnicas ainda não foi avaliada em animais de companhia (SZATMÁRI; HARKÁNYI; VÖRÖS, 2003),

A exposição até aqui realizada aponta a necessidade de novos estudos sobre o tema, razão pela qual foi empreendida esta investigação. Os objetivos do presente trabalho são:

1. Avaliar a acurácia do exame ultra-sonográfico em indicar o órgão abdominal afetado pelo processo neoplásico;

2. Determinar as características ultra-sonográficas dos diferentes tipos neoplásicos que acometem o fígado, intestinos e o pâncreas;

3. Analisar a eficácia da ultra-sonografia bidimensional em apontar a malignidade dos processos neoplásicos hepáticos e pancreáticos, bem como;

4. Analisar a eficácia da ultra-sonografia bidimensional em diferenciar processos neoplásicos intestinais de processos inflamatórios. 
2 Revisão da Literatura 


\section{REVISÃO DA LITERATURA}

De acordo com Bronson (1982), uma das principais causas de óbito em animais de companhia - cães e gatos - é o câncer. Na população estudada pelo autor, $45 \%$ dos cães que viveram 10 anos ou mais morreram de câncer. Em investigação realizada pela Morris Animal Foundation (1997) com 836 animais, 47\% dos indivíduos da amostra foram a óbito devido a enfermidades neoplásicas.

Em estudo sobre as causas de morte em 1206 cães das raças golden retriever, boxer, pastor alemão, labrador e rottweiller, Craig (2001) observou grande proporção de óbitos decorrentes de processos neoplásicos em animais das raças boxer e golden retriever. Os cães da raça boxer sabidamente apresentam alto risco para os processos neoplásicos, mas o autor observou índices similares também nos animais da raça golden retriever, e comprovou que o câncer foi a causa morte de $56,6 \%$ dos cães dessa última raça e de $51,9 \%$ dos boxers.

O diagnóstico por imagem, importante auxiliar na oncologia veterinária, evoluiu substancialmente nos últimos anos, principalmente com a inclusão de novas metodologias como a ultra-sonografia, a ultra-sonografia com duplex Doppler e Doppler colorido, a tomografia computadorizada e a ressonância nuclear magnética (BLEVINS, 2002). A eleição de um teste diagnóstico por imagem na clínica oncológica depende do conhecimento da fisiopatologia da moléstia, do órgão acometido, da dimensão da massa e das diferenças entre as técnicas imaginológicas (BRAGG, 1985).

Da mesma forma, a ultra-sonografia também tem grande valor na oncologia veterinária, pois possibilita a avaliação da arquitetura interna do parênquima (PENNINCK, 1998). Além disso, e um exame de baixo custo quando comparado a 
outras modalidades de imagem, como a tomografia computadorizada ou a ressonância nuclear magnética (HERRING, 1995).

Assim como relata Blevins (2002), a ultra-sonografia abdominal pode auxiliar no diagnóstico e no manejo do paciente com câncer, pois permite identificar o órgão alterado e as características ultra-sonográficas das lesões, quer sejam elas massas, quer sejam elas lesões infiltrativas.

No entanto, esse método apresenta limitações decorrentes de uma característica que lhe é intrínseca (RODRIGUES et al., 2002): em nenhuma outra das técnicas de diagnóstico por imagem, a interpretação do operador é tão importante para a obtenção de informações precisas (RESENDE, 1996). As imagens são produzidas e interpretadas em tempo real, o que, de acordo com Saunders (1998), exige o conhecimento das propriedades físicas do som e dos diferentes tipos de artefatos. Para a avaliação do abdômen devem ser utilizados equipamentos, transdutores e janelas acústicas apropriados quando possível, o paciente deve ser mantido em jejum, e eventuais mudanças de decúbito devem ser implementadas (RODRIGUES et al., 2002).

Na maioria das vezes, o exame sonográfico permite determinar o órgão afetado, o grau de invasão e a margem da lesão, à exceção das massas muito grandes, que tomam toda a cavidade abdominal (BLEVINS, 2002; MILES, 1997). Blevins (2002) lembra que nódulos e massas geralmente são anecóicos ou hipoecóicos quando comparados à ecotextura restante do parênquima avaliado, e podem ser de ecogenicidade homogênea ou complexa; as lesões complexas usualmente apresentam ecogenicidade mista. 
Quando as lesões neoplásicas apresentam-se sonograficamente de forma difusa, há maior dificuldade em diferenciá-las de processos inflamatórios (BLEVINS, 2002).

Apesar de a ultra-sonografia ser uma modalidade de imagem essencial para a detecção de neoplasias alojadas na cavidade abdominal de cães, o diagnóstico definitivo muitas vezes requer a biópsia e o exame histopatológico (JOHNSON, 2000; NYLAND et al., 2002a). Embora em medicina estudos tenham sido realizados com o objetivo de diferenciar as lesões benignas das lesões malignas com a ultrasonografia bidimensional, as limitações da imagem bidimensional fazem com que essa diferenciação ainda seja difícil (BOURNE et al., 1991). Por outro lado, Andolf (1993) comprovou que as características sonográficas de tumores ovarianos em mulheres se sobrepõem.

Nos tumores ovarianos da mulher, a comprovação de parâmetros morfológicos como septos, excrescências papilares, áreas de ecogenicidade aumentadas e presença de ascite, demonstrou ser de valor indicativo para malignidade (SASSONE et al., 1991).

Saunders (1998) e Vörös (1991) citam também que por meio do exame ultrasonográfico da cavidade abdominal de cães não é possível diferenciar os tipos histológicos tumorais. Todavia, alguns tipos histopatológicos apresentam singularidades que podem auxiliar o ultra-sonografista a emitir o diagnóstico e presumir o tipo de tumor (NYLAND et al., 2002a).

Almeida (2002) avaliou 30 cães com neoplasias abdominais, dos quais 14 apresentavam líquido livre abdominal: o exame ultra-sonográfico apresentou sensibilidade de $100 \%$ na detecção deste líquido. Não foram estudados os valores 
preditivos para malignidade associado à presença ou não do líquido livre abdominal nestes casos.

Para tentar corrigir a desvantagem e obter maior precisão no diagnóstico dos tumores - sem o emprego de outros métodos imaginológicos -, foram implementados recursos próprios à ultra-sonografia. A introdução da técnica Doppler acrescentou, ao exame ultra-sonográfico convencional, o estudo de fluxo sangüíneo. Abriu-se então um enorme campo de investigação dos tumores por meio de pesquisas de neovascularização, pois a presença de fluxo no interior das massas ou nódulos melhora a acuidade do diagnóstico das doenças malignas (LIN et al., 1997; PFLUGER et al., 1999; TANAKA et al., 1990; TANAKA et al., 1992).

\subsection{VASCULARIZAÇÃO TUMORAL E UTILIZAÇÃO DA TÉCNICA DOPPLER}

Há 40 anos a neovascularização tem sido considerada um elemento essencial no crescimento do tumor. Corroborando as investigações sobre angiogênese, Folkman (1985) e Folkman e Shing (1992) observaram que os tumores não crescem mais do que 1 a $2 \mathrm{~mm}$ após serem colocados em condições de isolamento. Enquanto implantes de células cancerosas de até $2 \mathrm{~mm}$ injetados em áreas avasculares câmara anterior do olho de coelhos - não se desenvolvem, esses mesmos implantes, quando colocados em áreas vasculares - coróides -, crescem rapidamente e desenvolvem um estroma altamente vascularizado (BONILLA-MUSOLES et al., 1992). O potencial que a célula tumoral tem de conservar as propriedades angiogênicas e restringir o crescimento tumoral na ausência de vascularização levaria à hipótese de que o crescimento do tumor é angiogênico-dependente 
(FOLKMAN, 1992). Por outro lado, a transformação maligna e o potencial angiogênico não estão sempre associados, pois cada um deles pode se manifestar na ausência do outro (FOLKMAN, 1992). Alguns tumores benignos, como por exemplo os adenomas de adrenais, podem apresentar fortes propriedades angiogênicas sem, entretanto, tornarem-se malignos. Similarmente, a microinvasão precede em muito a neovascularização (FOLKMAN, 1992). A angiogênese cumpre importante papel na transição de hiperplasias para neoplasia (FOLKMAN et al., 1989). Este é um evento independente, que pode fazer parte de diferentes estágios durante o desenvolvimento neoplásico (FOLKMAN, 1992).

Com relação aos aspectos clínicos das neoplasias malignas, é possível verificar o seu crescimento descontrolado e o seu propenso efeito invasor, ambos nitidamente relacionados a seu sistema vascular (SCHOR; SCHOR, 1991). A difusão passiva pode fornecer nutrientes suficientes e remover produtos inapropriados de pequenos tumores, mas o crescimento do diâmetro destes em alguns milímetros dependerá de novos vasos sangüíneos. A proliferação vascular é estimulada por agentes químicos conhecidos como fatores angiogênicos, secretados pelo tecido em crescimento. Alguns desses agentes químicos seriam os peptídios e as citocinas (FOLKMAN et al., 1971). A angiogênese normal ocorre durante o desenvolvimento embrionário e na vida adulta normal, durante a ovulação e a cicatrização de feridas (CERRI; MÓLNAR; VEZOZZO, 1998).

Em condições de benignidade, os novos vasos mostram organização e ramificações ordenadas, com regular diminuição de calibre até a fase de arteríolas, as quais têm estrutura normal, trilaminar, com endotélio intacto e uma camada completa de músculo liso que responde fisiologicamente aos estímulos neuronal e endócrino para manutenção do tono vascular. O fluxo destes vasos é regular, visto 
que o crescimento nos tecidos saudáveis tem altos requerimentos de oxigênio e nutrientes, e o tono vasomotor é baixo, com resistência de fluxo mínima (CERRI; MÓLNAR; VEZOZZO, 1998).

Os tumores também secretam fatores angiogênicos e, quando isto ocorre, a neovascularização é caracterizada por vasos de trajeto tortuoso, desordenadamente organizados e com alterações na estrutura de sua parede. Os vasos adotam estrutura complexa, com aparência entrelaçada e mudanças abruptas. Apesar disto, eles tendem a penetrar o tumor de maneira radiada. Quase sempre são verificadas conexões (Shunts) entre artérias adjacentes e entre artérias e veias, através das quais o fluxo sangüíneo é desviado, às vezes com alta velocidade (CERRI; MÓLNAR; VEZOZZO, 1998). A estrutura de ramificação ordenada é substituída por ramificações irregulares e muitas arteríolas que não têm continuidade formam, normalmente com capilares defeituosas dilatações saculares terminais. Além disto, a parede dos vasos neoformados nas neoplasias malignas é quase sempre incompleta, apresentando comunicações entre as células endoteliais - o que é justificado por sua anormal permeabilidade - e parcial presença de músculo liso. Certamente o fluxo sangüíneo que transita por estes vasos é irregular e com tono vasomotor deficiente (CERRI; MÓLNAR; VEZOZZO, 1998).

A vascularização dos tumores foi extensivamente estudada, graças à sua importância no crescimento destes e à sua capacidade de invadi-los. A ultrasonografia em efeito Doppler, em todas as suas formas, é um método particularmente promissor, não apenas pelo fato de não ser invasiva, mas também pela vantagem de prover informação dinâmica funcional com base anatômica. Ou seja, estudos que permitam avaliar quantitativa e qualitativamente a vascularização dos tumores adquirem significativa relevância (MACHADO; ROSA; CERRI, 2002). 
O Doppler colorido permite identificar a presença de vascularização nas lesões previamente detectadas pelo exame bidimensional. As lesões hepáticas, por exemplo, são dificilmente diferenciadas à imagem convencional. Tanaka et al. (1992) procuraram diferenciar o carcinoma hepatocelular de outras massas focais hepáticas com base no padrão de fluxo dentro e ao redor das lesões. Tais autores descreveram 4 padrões: 1. fina rede vascular circundando o nódulo - padrão rede de basquete -; 2. fluxo sangüíneo em direção central, ramificando-se para dentro da tumor - padrão vasos dentro do tumor -; 3.pontos coloridos ou remendos na região central do tumor - padrão mancha -;4. veia portal dilatada, circundando o nódulo padrão contorno. Eles sugeriram que os padrões rede de basquete e vasos dentro do tumor são característicos de carcinoma hepatocelular e que o padrão mancha ocorre mais freqüentemente nos hemangiomas, enquanto o padrão contorno seria mais observado em metástases. Por outro lado, Nino-Murcia et al. (1992), que trabalharam com diferentes tipos histológicos de lesões hepáticas focais, constataram que um número significativo de metástases apresentava o mesmo padrão de vascularização interna que os carcinomas hepáticos. O exame Doppler colorido é um adjunto na rotina ultra-sonográfica, auxiliando na caracterização de massas malignas (CERRI; MÓLNAR; VEZOZZO, 1998).

A utilidade do Doppler colorido, pulsado e em associação com contrastes ecográficos ainda estão sendo pesquisados, há inúmeras controversias sobre sua real utilidade. No estudo realizado por Blanco et al. (2003) verificou-se que o uso de contraste sonográfico foi capaz de identificar um grande número de vasos na totalidade dos tumores ovarianos, mas não melhorou a capacidade do Doppler na diferenciação entre tumores benignos ou malignos. Ou seja, embora a injeção de agentes produtores de microbolhas aumente a sensibilidade do método na 
diferenciação da natureza do tumor, este valor não se mostrou clinicamente útil na avaliação de tumores ovarianos.

Diferentes autores (NYLAND et al. 2002a; SZATMÁRI; HARKÁNY; VÖRÖS, 2003) vêm propondo estudos com a técnica Doppler na avaliação do fluxo tumoral em cães. Entretanto, em medicina veterinária, até o momento, sabe-se que a identificação das estruturas vasculares permite minimizar os riscos de hemorragia no momento da biópsia ou durante o ato cirúrgico. O Doppler colorido também é útil na diferenciação entre a porção necrótica tumoral e os vasos, o que evita que a porção necrótica ou vascular seja atingida durante a realização da biópsia ecodirigida (BLEVINS, 2002).

\subsection{NEOPLASIAS ABDOMINAIS EM CÃES}

Os tumores abdominais podem ser primários ou metastáticos. Tumores primários usualmente afetam locais únicos, enquanto as metástases podem se estender para diferentes regiões da cavidade abdominal (BLEVINS, 2002). Dentre as neoplasias abdominais inscrevem-se as neoplasias hepáticas, que respondem por cerca de 0,6 a 1,3\% de todas as neoplasias (PATNAIK et al. 1980); os tumores gástricos, que representam 1\% das neoplasias malignas (WITHROW, 2001a); as neoplasias intestinais, que respondem por menos de $1 \%$ de todas as neoplasias malignas (STRAW, 1996); e as neoplasias pancreáticas, consideradas raras, pois representam menos de $0,5 \%$ entre todas as neoplasias nos animais da espécie canina (WITHROW, 2001b). 


\subsubsection{NEOPLASIAS DE ORIGEM HEPÁTICA E ASPECTOS ULTRA-SONOGRÁFICOS}

O fígado pode ser acometido por neoplasias primárias ou metastáticas. Os tumores hepáticos primários são incomuns em cães, e podem ser de origem epitelial ou mesenquimal, benignos ou malignos. O tumor benigno dos hepatócitos é denominado adenoma hepatocelular (ou hepatoma), enquanto o tumor maligno epitelial é denominado carcinoma hepatocelular. O carcinoma hepatocelular é a neoplasia maligna primária hepática mais comum em cães (HAMMER; SIKKEMA, 1995; PAITNAIK et al., 1980; STRAW, 1996).

Em relação às neoplasias linfóides que acometem o fígado, o linfoma é predominante em animais da espécie felina. Acredita-se que a mesma prevalência ocorra em cães, todavia, nem sempre o parênquima hepático dos cães com linfoma é biopsiado (HAMMER; SIKKEMA, 1995).

Os tumores originados nos ductos biliares são denominados cistoadenomas biliares quando benignos, e colangiocarcinomas quando malignos. $\mathrm{O}$ colangiocarcinoma pode ser intra-hepático, extra-hepático ou da vesícula biliar (JOHNSON, 2000).

O carcinoma hepatocelular e o colangiocarcinoma ocorrem sob a forma de massas solitárias, lesões multifocais nodulares ou infiltração difusa em grandes porções do parênquima (JOHNSON, 2000). Massas solitárias ocorrem em 50\% dos casos de carcinoma hepatocelular, e em aproximadamente $33 \%$ de cães com colangiocarcinoma (HAMMER; SIKKEMA, 1995). Metástases extra-hepáticas são verificadas em ambos os tipos histológicos citados anteriormente, embora sejam mais freqüentes nos casos de carcinoma hepatocelular. Linfonodos hepáticos, 
cavidade peritoneal e pulmões são os locais normalmente envolvidos, mas outros sítios de metástases podem ocorrer (JOHNSON, 2000).

Os tumores hepáticos primários de origem mesenquimal (sarcomas) são incomuns, enquanto o hemangiossarcoma e o leiomiossarcoma tenham sido descritos com maior freqüência (STRAW, 1996).

As metástases hepáticas podem originar-se de neoplasias do trato gastrintestinal ou pâncreas, adenocarcinoma mamário, hemangiossarcoma e linfoma (STRAW, 1996).

Freqüentemente, as causas do desenvolvimento das neoplasias hepáticas primárias em cães não são determinadas. Causas potenciais, como aflatoxinas, nitrosaminas, parasitas hepáticos e componentes radioativos como strontium 90 e cesium 144 já foram relatadas em estudos experimentais e como achados espontâneos (JOHNSON, 2000). Ao contrário do relatado na medicina humana, não existe associação entre a incidência de tumores hepáticos e as infecções virais (JOHNSON, 2000). Outro aspecto, citado em estudo clínico realizado por Paitnaik et al. (1980), é que o carcinoma hepatocelular não tende a se desenvolver em fígados cirróticos.

Os tumores hepáticos primários são observados em cães com idade superior a 10 anos; os cães machos apresentam maior risco para o desenvolvimento de carcinoma hepático, enquanto as fêmeas têm maior tendência para o desenvolvimento de colangiocarcinoma (HAMMER; SILKEMMA, 1995).

Em cães com neoplasia hepática, os sinais clínicos geralmente são vagos e pouco específicos; sinais de disfunção hepática normalmente só aparecem quando o tumor encontra-se em estágio avançado. Os sinais clínicos mais consistentes dessa moléstia são anorexia, letargia, perda de peso, poliúria, polidipsia, vômitos e 
distensão abdominal. Outros sinais, menos comuns, são icterícia, diarréia e sangramento. Ao exame físico, massa abdominal cranial ou marcante hepatomegalia são freqüentemente detectadas em cães com tumor hepático primário. Habitualmente, a hepatomegalia não ocorre em pacientes com metástases hepáticas. A ascite e o hemoperitôneo podem contribuir no achado de distensão abdominal (HAMMER; SIKKEMA, 1995; JOHNSON, 2000).

Ruptura do tumor e hemorragia são mais freqüentemente observadas nos casos de adenoma hepatocelular, carcinoma hepatocelular e hemangiossarcoma hepático. Anemia e mucosas pálidas podem ser atribuída à doença crônica hepática ou à ruptura da neoplasia. A icterícia é incomum em cães, a não ser que a massa comprima as vias biliares (HAMMER; SIKKEMA, 1995). Os achados laboratoriais também são pouco específicos, e podem indicar a presença de doença hepática e suas complicações (JOHNSON, 2000).

Em investigação realizada por Gonzalez (2002), 11 de 18 animais da espécie canina com afecções hepatobiliares devido a síndrome abdome agudo apresentavam massas hepáticas, o que sugere a importância de se aventar a possibilidade de massas hepáticas em sintomas relacionados a abdome agudo no cão.

O exame ultra-sonográfico é uma técnica extremamente útil na avaliação hepática quando da suspeita de neoplasias primárias ou metastáticas (WHITELEY et al., 1989). A detecção, no parênquima hepático, de lesões compatíveis a neoplasias é a aplicação diagnóstica mais importante da ultra-sonografia hepatobiliar. Nyland et al. (2002a) recomendam o screening de cães velhos com hepatomegalia, para descartar ou confirmar a hipótese de neoplasia. 
O aspecto ultra-sonográfico do parênquima hepático do cão é uniforme, com um nível médio de ecogenicidade: somente as veias portas e as veias hepáticas interrompem a arquitetura uniforme do parênquima. A ecogenicidade do fígado normalmente é semelhante à do córtex renal, ou o fígado é ligeiramente mais hiperecóico. O baço apresenta uma intensidade de ecogenicidade bem maior que aquela do parênquima hepático. A vesícula biliar é geralmente anecóica, oval, localizada justamente na linha média direita (NYLAND et al., 2002a).

Autores como Barr (1992) e Goldshalk et al. (1988) realizaram estudos de mensuração hepática na tentativa de padronizar o volume hepático em cães. Todavia, ainda há grande discordância sobre a eficácia desses métodos de mensuração. Devido a isso, a determinação do tamanho hepático no cão normalmente é baseada no método subjetivo, e as diferenças de raça e de conformação corpórea devem ser consideradas quando da interpretação (NYLAND et al., 2002a).

Suspeita-se de hepatomegalia quando ocorrem aumento na distância entre o diafragma e o estômago, extensão do lobo hepático para a porção ventral da cavidade abdominal e visualização das margens hepáticas arredondadas (NYLAND et al., 2002a). A suspeita de fígado reduzido de tamanho é decorrente de pobre visibilização do parênquima, diminuição da distância entre o diafragma e o estômago e menor extensão do parênquima na porção ventral da cavidade abdominal (NYLAND et al., 2002a).

A aparência sonográfica da neoplasia é determinada pela homogeneidade de seu tipo celular, pela quantidade de vascularização, pela extensão da hemorragia ou necrose, pela presença de tecido fibroso e pela deposição de minerais (SAUNDERS, 1998). 
Os tumores hepáticos primários e secundários apresentam manifestações ultra-sonográficas amplamente variáveis, incluindo o padrão normal. Esta variação de configurações lesionais ocorre tanto entre diferentes tipos de tumores quanto entre os iguais. Tumores histologicamente diferentes podem apresentar imagens semelhantes. Apesar desta sobreposição de achados, e embora a biópsia seja imprescindível para o diagnóstico definitivo do tipo neoplásico, a ultra-sonografia pode sugerir linhas gerais de orientação das lesões tumorais (NYLAND et al., 2002a).

O linfoma hepático do cão pode apresentar lesões hiperecóicas focais ou multifocais distribuídas por todo o parênquima, lesões hipoecóicas e lesões em "alvo" (LAMB; HARTZBAND; TIDWELL, 1991; PARTINGTON; BILLER, 1995); aspectos infiltrativos também já foram descritos como padrão difuso hipoecóico ou hiperecóico (NYLAND et al., 2002a; PARTINGTON; BILLER, 1995). O linfoma hepático pode representar somente uma parte do envolvimento tumoral, o que indica a necessidade de empreender cuidadoso exame para detectar linfonodomegalia abdominal e envolvimento esplênico (PARTINGTON; BILLER, 1995).

Massas hiperecóicas e solitárias estão quase sempre associadas ao carcinoma hepatocelular (WHITELEY et al., 1989). Lesões hipoecóicas focais ou múltiplas não se relacionam a um tipo específico, enquanto que focos hiperecóicos, usualmente, revelam carcinomas (FENNEY; JOHNSON; HARDY, 1984).

No estudo publicado por Whiteley et al. (1989), cuja amostra contemplava 15 cães com carcinoma hepatocelular, 14 (93,3\%) animais apresentavam massas solitárias hiperecóicas. Desses 14 cães, áreas de necrose central massiva foram observadas somente em um animal, e sete dos demais casos apresentavam lesões maiores que $10 \mathrm{~cm}$ de diâmetro, embora não cavitárias. 
Em homens, o carcinoma hepatocelular - dependendo do tamanho e estágio pode aparecer como lesões focais de ecogenicidade variável, ou apresentar-se como uma distorção difusa da arquitetura do parênquima, sem a identificação de massa (MACHADO; ROSA; CERRI, 2002). Estas características sonográficas estão relacionadas ao tipo macroscópico dos carcinomas hepatocelulares, que tem sido historicamente dividido em padrão nodular, em "massa" e difuso (MACHADO; ROSA; CERRI, 2002). De interesse sonográfico é que todos os padrões macroscópicos descritos anteriormente podem ser reconhecidos. Assim, para se obter um alto índice de detecção, possibilitando o início precoce da terapêutica, otimizando a sobrevida dos pacientes, o examinador deve conhecer todas as variações de apresentação dos carcinomas hepatocelulares (MACHADO; ROSA; CERRI, 2002).

$\mathrm{Na}$ medicina, além daquelas formas de apresentação macroscópicas descritas anteriormente, devem ser considerados os "pequenos" carcinomas, tumores menores ou iguais a 2,0cm cujo prognóstico é significativamente melhor que aquele dos tumores maiores, ou seja, de tamanho superior a 2,0 cm. Os aspectos ultra-sonográficos dos "pequenos" carcinomas são variáveis, identificando-se muitas vezes aspecto em "mosaico", com formação de septos ecogênicos, halo periférico, sombra lateral - devido à pseudocapsula fibrosa -, e reforço acústico posterior decorrente da diferença de textura entre o nódulo e o parênquima cirrótico adjacente (MACHADO; ROSA; CERRI, 2002). Quando os nódulos são pequenos, o padrão usual tende a ser hipoecogênico, embora, em alguns casos, tais lesões possam se apresentar sob a forma de nódulos hiperecogênicos. Tumores com aspecto hipoecogênico e heterogêneos também ocorrem com freqüência. Os nódulos - ou áreas intratumorais - hiperecóides podem representar transformação gordurosa, 
arranjo pseudoglandular das células neoplásicas, alterações nos aspectos vasculares tumorais, ou ainda alterações fibróticas no tumor. Ocasionalmente, os nódulos podem assumir o aspecto em "alvo" (MACHADO; ROSA; CERRI, 2002).

No homem, as formas de apresentação ultra-sonográfica dos carcinomas maiores que $2,0 \mathrm{~cm}$ também são variadas, correlacionando-se com os aspectos macroscópicos. Podem apresentar um padrão "mosaico" e com aspecto heterogêneo, decorrente das mesmas alterações descritas para os "pequenos" carcinomas, ou seja, a apresentação ultra-sonográfica do carcinoma hepático no homem é variável: os maiores também podem assumir o aspecto de nódulos, com maior ecogenicidade e com configuração que também se assemelha àquela de "olho de boi" ou em "alvo" - quando a periferia da lesão apresenta ecogenicidade diferente do seu centro. Assim como para os carcinomas "pequenos", esta diversidade decorre da variação da composição citoarquitetural - vasos, septos e principalmente gordura - dos carcinomas maiores, e da ocorrência de fenômenos como hemorragia e necrose (MACHADO; ROSA; CERRI, 2002).

A avaliação dos carcinomas hepatocelulares com o Doppler demonstra sinais internos de fluxo na maioria das lesões, assim como vascularização periférica, correspondendo aos achados da anatomia patológica, que demonstram que tais lesões são bem vascularizadas. A análise espectral com o Doppler deve avaliar sobretudo a velocidade máxima do fluxo, o índice de pulsatividade e de resistência, revelando a presença de vasos arteriais com fluxo de baixa resistência. Por outro lado, a avaliação com o Doppler colorido pode demonstrar a presença de padrão em “rede de cesto", que sugeriria o carcinoma hepático (GONZÁLEZ-AÑÓN et al., 1999; MACHADO; ROSA; CERRI, 2002). 
Embora revele de maneira bastante objetiva a vascularização dessas lesões, a avaliação com o Doppler colorido apresenta semelhanças com padrões de outros tipos de tumores hepáticos malignos e benignos. Por outro lado, mesmo nos carcinomas o padrão pode variar, pois algumas lesões apresentam-se bem mais vascularizadas que outras, na dependência de fenômenos como infiltração gordurosa e necrose, que ocorrem com freqüência nesse tipo de neoplasia. Investigações com Doppler de amplitude têm sido empreendidas com êxito, e o equipamento tem se mostrando bastante sensível na detecção dos fluxos intratumoral e perilesional, independentemente da velocidade ou da direção destes. O Power Doppler apresenta alta sensibilidade para a detecção de fluxos de baixa velocidade (MACHADO; ROSA; CERRI, 2000).

Atualmente, os meios de contraste para a ultra-sonografia podem ser utilizados para o estudo das lesões hepáticas. Essa técnica amplifica os ecos oriundos do fluxo vascular, aumenta a sensibilidade de detecção da vascularização dentro do nódulo, permite maior eficácia no diagnóstico diferencial pelo Doppler colorido, e possibilita constatação mais precoce e melhor avaliação no seguimento de pacientes com carcinoma hepatocelular (MACHADO; ROSA; CERRI, 2002).

A avaliação com Doppler e agentes de contraste pode contribuir grandemente para a investigação de tumores hepáticos em pequenos animais, a exemplo do que ocorre na medicina humana (NYLAND et al., 2002a; SZATMÁRI; HARKÁNY; VÖRÖS, 2003).

Whiteley et al. (1989) descreveram a aparência sonográfica de quatro casos de colangiocarcinoma hepático: nos animais avaliados, um apresentava nódulos múltifocais hiperecóicos, um tinha nódulos multifocais hipoecóicos e dois 
apresentavam nódulos mistos multifocais, dos quais um apresentava, em conjunto com os nódulos, uma massa solitária em um dos lobos hepáticos.

A classificação dos colangiocarcinomas humanos é realizada em função de seu local de origem. Os colangiocarcinomas intra-hepáticos podem ser classificados em três tipos básicos: colangiocarcinomas periféricos, que se originam dos ductos biliares pequenos; interlobulares; colangiocarcinomas dos ductos hepáticos maiores, que se originam dos ductos biliares maiores, próximos ao hilo hepático; e colangiocarcinomas hilares - denominados tumores de Klatskin -, que se originam na confluência dos ductos hepático direito e esquerdo (FERNANDEZ; REDVANLU, 1998).

$\mathrm{Na}$ medicina, as características ultra-sonográficas descritas dos colangiocarcinomas intra-hepáticos são: lesões hipoecogênicas, lesões isoecogênicas e lesões hiperecogênicas. De maneira geral, predomina (cerca de $75 \%$ dos casos) o aspecto mais ecogênico das lesões, relativamente homogêneo. Em outras ocasiões, as lesões são predominantemente heterogêneas. Nas lesões que se localizam mais ao centro, é usual encontrar dilatações da árvore biliar em graus variados. Mesmo nas lesões mais periféricas, a análise cuidadosa revela alguns canais biliares dilatados, além de degeneração cística, também relatada na literatura. Ocasionalmente, podem ser observados nódulos satélites à lesão maior (MACHADO; ROSA; CERRI, 2002).

Esses tumores apresentam tendência à invasão de ramos portais, o que contribui para a atrofia do setor hepático que suprido por estes. Esse aspecto pode ser observado com certa freqüência nos colangiocarcinomas, e determina retrações na superfície do fígado. Os exames de imagem identificam sinais de invasão de ramos portais em até $50 \%$ dos casos, seja pela evidenciação direta do 
comprometimento vascular - tumor no interior do vaso -, seja pelos sinais indiretos dessa invasão - como compressão vascular determinando irregularidades de contornos ou redução volumétrica do setor hepático a montante da lesão (MACHADO; ROSA; CERRI, 2002).

O Doppler possibilita a identificação de vascularização nas lesões. Mesmo que o Doppler colorido demonstre predominantemente fluxo perilesional, o uso de contraste endovenoso para ultra-sonografia pode mostrar evidente vascularização intra e perilesional (MACHADO; ROSA; CERRI, 2002).

O hemangiossarcoma hepático no cão pode ser classificado como primário somente no fígado - ou multicêntrico. Aspectos ultra-sonográficos descritos em três casos foram nódulos multifocais hipoecóicos ou mistos, estes últimos classificados como hemangiossarcoma hepático multicêntrico (WHITELEY et al., 1989). Nyland et al. (2002a) ressaltam que nódulos focais ou multifocais hipoecóicos não devem ser correlacionados a nenhum tipo histológico específico de tumor.

A hiperplasia nodular hepática é considerada um dos principais diferenciais para a neoplasia em cães velhos com alterações ultra-sonográficas no parênquima. Pode ocorrer em cerca de $70 \%$ dos cães idosos, mas as lesões não são freqüentemente identificadas durante o exame sonográfico. A hiperplasia nodular benigna usualmente não está relacionada a sinais clínicos, contudo pode haver uma leve a moderada alteração das enzimas hepáticas ao exame laboratorial. De fato, a grande importância clínica dessa enfermidade é a possibilidade de confundir o diagnóstico de neoplasia hepática quando os nódulos são identificados no exame sonográfico (JOHNSON, 2000; PRAUSE; TWEDT, 2000). 
A aparência ultra-sonográfica dos nódulos da hiperplasia é bastante variável, correspondendo às suas alterações histológicas. Como anteriormente citado, os nódulos podem não ser detectados na ultra-sonografia devido à ecogenicidade similar com o parênquima hepático, ou apresentarem características isoecóicas, moderadamente hiperecóicas ou de ecogenicidade mista (NYLAND et al., 2002a). Nyland et al. (2002a) relatam que a hiperplasia pode ser similar a hematomas, abscessos, áreas de necrose e neoplasias primárias ou metastáticas. Muito embora a biópsia hepática seja indicada, por vezes é difícil distinguir histologicamente hiperplasia, adenoma hepatocelular ou carcinoma hepatocelular bem diferenciado. De qualquer forma, a biópsia hepática é importante na tentativa de diferenciar a neoplasia hepática de outras doenças.

Em medicina, a hiperplasia nodular focal é considerada a segunda causa mais comum de massas sólidas benignas no fígado, com incidência de 1 a 3\%. Acomete preferencialmente mulheres, com predominância na terceira, quarta e quinta décadas de vida. Em $65 \%$ dos casos, mede menos de $5 \mathrm{~cm}$ e usualmente é um achado acidental durante o exame. O aspecto de lesões múltiplas é visto em $20 \%$ dos casos. Histologicamente, os nódulos são compostos por constituintes hepáticos normais - hepatócitos, células de Kupffer e ductos biliares -, em um arranjo anormal e bem delimitado por uma cápsula fibrosa. Uma cicatriz central estrelada, achado característico, ocorre em $45 \%$ dos casos. Como regra, não se encontram áreas de necrose e hemorragia. Os casos de hemorragia parecem ser ocasionais, diferentemente do que se observa nos adenomas hepáticos (HARVEY; ALBRECHT, 2001; MACHADO; ROSA; CERRI, 2002).

O Doppler pode revelar a presença de vascularização periférica evidente, observando-se também vasos nas porções centrais. Esses vasos centrais podem se 
distribuir em padrões lineares ou estrelados. O Doppler colorido pode evidenciar também fluxo na cicatriz central - denominado de aspecto em "roda de carroça" por alguns autores. Esse achado auxilia no diagnóstico, uma vez que, via de regra, a cicatriz central apresenta-se com vascularização proeminente (HARVEY; ALBRECHT, 2001; MACHADO; ROSA; CERRI, 2002). Todavia, nódulos pequenos de hiperplasia hepática podem apresentar esse mesmo aspecto, e ser facilmente confundidos com metástases, especialmente em mulheres jovens com tumor de mama (HARVEY; ALBRECHT, 2001).

A medicina humana descreve os adenomas dos ductos biliares como lesões benignas e comumente assintomáticas, cuja localização é usualmente subcapsular, e com dimensões que variam de $1 \mathrm{~mm}$ a $1 \mathrm{~cm}$. Os adenomas são constituídos por dúctulos biliares e quantidade variável de reação inflamatória e fibrose. O aspecto ultra-sonográfico pode demonstrar múltiplas pequenas áreas de baixa ou alta ecogenicidade, dependendo da relação entre o tamanho das lesões e a refletividade das interfaces pelas quais o som irá ultrapassar. Embora possam ser únicos ou múltiplos, mais comumente são bastante numerosos, apresentando-se como imagens sólidas, hipoecogênicas. Outras vezes são hiperecogênicas ou em aspecto de lesões em "alvo" (MACHADO; ROSA; CERRI, 2002). Na medicina veterinária ainda não foram descritas as características ultra-sonográficas específicas para o cistoadenoma de vias biliares no cão.

Somente um trabalho de comprovação de parâmetros morfológicos ultrasonográficos em tumores abdominais hepáticos e esplênicos foi realizado em cães e gatos com o intuito de demonstrar seu valor preditivo para malignidade. Essa investigação retrospectiva, conduzida por Cuccovillo e Lamb (2002), estudou especificamente o valor preditivo de malignidade dos nódulos em "alvo" no fígado ou 
no baço de cães e gatos. A amostra era constituída por 20 cães e um gato que apresentavam nódulos em "alvo"; ao exame histopatologico, 12 das 16 lesões em "alvo" hepáticas revelaram-se malignas, bem como cinco das sete lesões em "alvo" esplênicas. Nessa série, o achado ultra-sonográfico de uma ou duas lesões em "alvo" no fígado ou no baço teve um valor preditivo para malignidade de $74 \%$; quando verificadas múltiplas lesões de aspecto em "alvo" em um órgão, o valor preditivo para malignidade foi de $81 \%$. Os quadros benignos correlacionados a esse aspecto foram: hiperplasia nodular do fígado ou do baço, hepatite piogranulomatosa, cirrose e hepatite ativa crônica.

O potencial de diagnóstico histopatológico incorreto relacionado às imagens das lesões focais em "alvo" nesse estudo e o pequeno número de animais estudados, faz com que fique difícil representar o real valor preditivo para malignidade destas lesões, a conclusão que os autores chegaram foi que, os nódulos alvo não indicam um diagnóstico específico, apesar do alto valor preditivo para malignidade (CUCCOVILLO; LAMB, 2002).

Os demais aspectos sonográficos das diferentes enfermidades hepáticas no cão foram substancialmente descritos, destacando-se a cirrose hepática, cuja principal característica ultra-sonográfica é o fígado reduzido de tamanho, de contorno irregular, aumento difuso da ecogenicidade e ascite. No cão, assim como no homem, os nódulos de regeneração que podem acompanhar os quadros de hepatite crônica e cirrose, quando vistos ultra-sonograficamente, apresentam contorno regular, acompanhados pelo parênquima reduzido de tamanho, e fígado ecogênico decorrente de fibrose e calcificação distrófica (NYLAND et al., 2002a). 


\subsubsection{NEOPLASIAS DE ORIGEM INTESTINAL E ASPECTOS ULTRA-SONOGRÁFICOS}

A incidência de neoplasias gastrintestinais é baixa, representando cerca de $2 \%$ de todas as neoplasias em cães e gatos, e o intestino é mais acometido do que o estômago (MAGNE, 2000). Entretanto, os tumores gastrintestinais têm grande impacto nos pacientes veterinários, pois muitas vezes o diagnóstico somente é elucidado nos estágios avançados da doença, quando há alta porcentagem de metástases. O adenocarcinoma é a neoplasia mais comum no trato gastrintestinal de cães, seguida pelo linfoma, pelo leiomiossarcoma e pelo leiomioma. A maioria dos cães com tumores no trato gastroentérico está na meia idade - 7 a 10 anos -, e existe uma predisposição sexual para machos nos casos de adenocarcinoma e linfoma.

Esses animais apresentam uma história típica de disfunção crônica profunda do trato gastroentérico, e os sinais clínicos associados incluem vômito, hematoemese, hematoquesia, melena, tenesmo ou disquesia, perda de peso, letargia e, em alguns casos, edema decorrente de profunda perda protéica (MAGNE, 2000).

Em alguns casos, os sinais clínicos são de característica aguda, mimetizando outras causas de processos obstrutivos, como corpos estranhos, intussuscepções ou outras desordens intestinais. Perfurações das neoplasias gastrintestinais também podem ocorrer, levando a peritonite séptica e rápida deterioração do estado clínico do animal (MAGNE, 2000).

As anormalidades detectadas ao exame físico variam, e podem incluir: caquexia, massa abdominal à palpação, espessamento intestinal difuso, 
hepatomegalia, esplenomegalia, linfonodomegalia regional ou difusa, edema subcutâneo, dor abdominal e mucosas pálidas (MAGNE, 2000).

A utra-sonografia abdominal é rotineiramente requerida em pacientes suspeitos de neoplasias gastroentéricas, e muitas vezes é suficiente para eliminar diagnósticos diferencias (MAGNE, 2000), principalmente a doença intestinal inflamatória crônica (HALL; SIMPSON, 2000).

A endoscopia gastrintestinal também é um importante método diagnóstico auxiliar nas regiões em que é acessível, como o estômago, o duodeno, a região colo retal e talvez a região de íleo (MAGNE, 2000).

Sob ótimas condições, é possível identificar ultra-sonograficamente todas as camadas parietais gastrintestinais que, do lúmen para fora, correspondem: a face da mucosa que é visibilizada como uma linha hiperecóica; seguindo para as porções mais externas, mucosa-hipoecóica, submucosa-hiperecóica, muscular própriahipoecóica e subserosa/serosa-hiperecóica (PENNINCK; NYLAND; FISHER, 1989).

No lúmen são descritos 4 tipo de constituintes: o fluido, que é anecóico; o muco, que se apresenta como material ecogênico sem sombreamento acústico; o ar, que apresenta reflexão com sombreamento acústico; e o alimento, anecóico com pontos ecogênicos (PENNINCK; NYLAND; FISHER, 1989).

A espessura parietal do intestino delgado em cães é de 2,0 a 4,0mm. Esta medida corresponde à distância entre a face da mucosa - porção hiperecóica mais interna - e a serosa - porção hiperecóica mais externa (PENNINCK; NYLAND; FISHER, 1989). O duodeno proximal é estudado na região crânio-ventral do abdome, adjacente ao rim direito e aos lobos hepáticos direitos; este segmento é levemente mais espesso que o restante das alças. A espessura da parede do 
duodeno em cães normais é de cerca de $5 \mathrm{~mm}$ em raças grandes, $4 \mathrm{~mm}$ em raças médias e 3mm em raças de pequeno porte (PENNINCK, 2002).

Os demais segmentos do intestino delgado localizam-se na região média do abdome e, para o exame, o baço e a bexiga são utilizados como janela acústica. No cão, o ceco é de difícil localização porque, na maioria das vezes, está preenchido por gases (PENNINCK, 2002).

Embora o exame ultra-sonográfico não seja adequado para a avaliação do intestino grosso devido ao conteúdo luminal fecal e/ou gasoso, o cólon descendente pode ser identificado pela imagem em forma "C" produzida pelo gás dorsalmente à bexiga urinária. Normalmente, a parede é mais fina que o restante do trato gastroentérico (HOMCO, 1996).

A principal limitação da ultra-sonografia das vísceras ocas é a presença de gás - dentro ou fora das alças -, que é responsável por fenômenos como reverberação, cauda de cometa e sombreamento (PENNINCK; NYLAND; FISHER, 1989).

O exame ultra-sonográfico é a modalidade diagnóstica de imagem mais eficiente e menos invasiva na detecção de tumores gastrintestinais em pequenos animais (PENNINCK, 1998). Por meio desse exame, é possível avaliar as paredes gástrica e intestinal, classificar a extensão da lesão (focal, multifocal ou difusa), avaliar os demais órgãos da cavidade abdominal na procura de metástases e na identificação de linfonodomegalia, e selecionar o método de biópsia mais adequado para o paciente em questão: ecodirigida, endoscópica ou cirúrgica (PENNINCK, 2002).

No homem, geralmente o espessamento parietal em neoplasias é de aspecto irregular, hipoecogênico, heterogêneo, eventualmente com áreas anecóides no 
interior, correspondendo a necrose. O crescimento pode ser assimétrico e excêntrico, observando-se também perda da estratificação parietal normal. A alça adquire aspecto rígido, com redução do peristaltismo e, eventualmente, distensão luminal. Outra característica é a transição abrupta entre o segmento de alça doente e o segmento normal (RIBEIRO; VENTURA; BARROS, 2002).

O adenocarcinoma é relativamente comum em cães de meia idade a idosos, podendo se localizar em qualquer porção intestinal; aparentemente existe uma predisposição para a região do reto em cães. Tipicamente, apresenta-se como uma infiltração local que causa lesão anelar constritiva, e pode levar a um quadro de estenose e eventual obstrução intestinal, embora um aspecto de nódulos polipoídes também possa ocorrer, principalmente na região do reto e do cólon (MAGNE, 2002). Ocasionalmente, uma forma variante e de aspecto difuso infiltrativo, pode ser diagnosticada (MAGNE, 2000).

As características ultra-sonográficas mais freqüentemente relatadas nos casos de adenocarcinoma intestinal no cão são: espessamento parietal localizado e irregular, perda da integridade da arquitetura das camadas, e adenomegalia regional. Esse mesmo aspecto, na maioria das vezes anelar e constritivo, promove o estreitamento luminal e o acúmulo de fluido proximal (PENNINCK, 2002). Em alguns casos, é difícil acessar a extensão da lesão em comprimento, porque ela pode ser maior que o campo de leitura do transdutor (PENNINCK, 1998).

Nos casos de adenocarcinoma intestinal pode haver presença de corpos estranhos proximais ao ponto de constrição. A imagem hiperecóica com forte sombreamento acústico posterior é o achado mais evidente de corpos estranhos e de fácil caracterização. Todavia, essa imagem se sobrepõe àquela resultante de 
alteração de parede, provocando um falso negativo para tumor intestinal (GONZALEZ, 2002).

O linfoma é o tumor hematopoiético relacionado à proliferação de linfócitos de etiologia desconhecida no cão. O linfoma quase sempre acomete os intestinos de animais dessa espécie, embora as formas extra-intestinais sejam mais comuns. Assim como outras neoplasias do trato gastrintestinal, aparentemente existe uma maior predisposição de acometimento para os machos (MAGNE, 2000). As características clínicas observadas no linfoma são: perda de peso progressiva, diarréia e/ou vômito; sinais extra-intestinais como linfadenopatias podem ou não ocorrer (NELSON; COUTO,1992). A hipoproteinemia decorrente da perda protéica intestinal é comum. O linfoma pode ter nódulos discretos nas alças, apresentar-se sob a forma de doença infiltrativa ou causar constrições focais (MAGNE, 2000).

Quase todos os trabalhos que descrevem as características sonográficas do linfoma do trato digestório foram realizados em felinos (GROOTERS et al., 1994). De qualquer forma, Penninck (1998) cita que, na espécie canina, os mesmos aspectos são visualizados.

Os achados sonográficos de linfoma intestinal: são os espessamentos transmurais, com perda de definição de camadas, a ecogenicidade reduzida, a diminuição localizada da motilidade e a adenomegalia mesentérica regional (PENNINCK, 1994; GROOTERS et al., 1994). Os espessamentos podem ser de dois diferentes tipos: transmural segmentar circunferencial, transmural nodular, ou por infiltração difusa, sendo este último o mais difícil de diferenciar de doença inflamatória intestinal idiopática crônica. De todos estes padrões, o mais comum é o transmural segmentar circunferencial, que pode ser simétrico ou assimétrico (PENNINCK, 1998). 
$\mathrm{Na}$ medicina humana, o termo TUMORES DE ESTROMA tem sido preferencialmente usado para designar a classe dos tumores mesenquimais benignos ou malignos -, da qual fazem parte o leiomioma, o leiomiossarcoma e o lipoma. A maioria desses tumores origina-se da camada muscular própria da alça envolvida, sendo difícil a distinção entre benigno e maligno com base apenas nos aspectos macroscópico e microscópico da lesão, exceto quando a agressividade do tumor é caracterizada pela invasão local ou pela presença de metástases. Geralmente, o crescimento é extrínseco, extraluminal, formando grandes massas intraperitoneais, sendo que apenas $7 \%$ apresentam crescimento predominantemente endoluminal (RIBEIRO; VENTURA; BARROS, 2002).

O leiomiossarcoma intestinal no cão é a neoplasia que afeta a musculatura lisa do intestino. Seus sinais clínicos, assim como aqueles de outras neoplasias intestinais, são: vômito, anorexia, letargia e perda de peso. Todavia, em investigação realizada por Myers e Penninck (1994) em 11 cães com leiomiossarcoma gastrintestinal, cerca de $20 \%$ não apresentaram sinais clínicos relacionados ao sistema digestório; as anormalidades detectadas incluíram palidez das mucosas, febre, fadiga muscular e massa abdominal.

Quanto ao aspecto ultra-sonográfico, os leiomiossarcomas geralmente são grandes lesões exofílicas - massa parietal extrínseca -, heterogêneas - com áreas hipo/anecóicas - e com perda de estratificação de camadas; efusão peritoneal também pode ser visualizada. A presença de gás intraluminal na massa ou a ela adjacente auxilia a determinar a localização e a associação com um segmento intestinal. A ultra-sonografia também pode revelar adenomegalia mesentérica e nódulos mistos - hipo ou hiperecóicos - no fígado (MYER; PENNINCK, 1994). 
Como anteriormente mencionado, a presença de gás ou fezes no cólon afeta significativamente a avaliação ultra-sonográfica desta porção intestinal. Algumas vezes, fezes uniformes e macias podem ser confundidas com processos neoplásicos (PENNINCK, 2002).

Alguns tipos neoplásicos acometem o intestino grosso de cães. Os pólipos adenomatosos colorretais são os tumores mais freqüentes, mas carcinomas e tumor carcinoíde já foram descritos (MAGNE,2000).

Os adenomas colorretais estão freqüentemente relacionados a sintomas de tenesmo, hematoquesia ou até mesmo prolapso. Embora a transformação maligna dos pólipos colorretais ocorra comumente no homem, isto parece ser bem raro nos cães, e foi descrito somente uma vez na literatura médico-veterinária (MAGNE, 2000).

As características ultra-sonográficas das neoplasias do intestino grosso de cães ainda não foram descritas. Nos gatos, o adenocarcinoma e o linfoma mostram um significativo espessamento parietal - maior que $8 \mathrm{~mm}$-, com perda da arquitetura das camadas. A linfonodomegalia regional é facilmente detectada e monitorada (PENNINCK, 2002).

A neoplasia maligna do cólon representa uma das doenças gastrintestinais potencialmente letais mais encontrada na prática clínica diária em medicina humana. O tipo histológico mais comum é o adenocarcinoma. Ao ultra-som, os achados refletem o comportamento patológico destes tumores, e evidenciam dois padrões principais de alterações: espessamento parietal segmentar e massa sólida heterogênea, atingindo até $10 \mathrm{~cm}$ e apresentando tanto crescimento intraluminal como extrínseco. As lesões que se apresentam como espessamento parietal segmentar anelar têm aspecto assimétrico, contornos irregulares, peristaltismo 
ausente, estreitamento da luz e padrão em "alvo". Outra característica importante é a transição abrupta entre o segmento de alça normal e o segmento patológico (RIBEIRO; VENTURA; BARROS, 2002).

As massas sólidas geralmente têm contornos lobulados, irregulares e são hipoecogênicas heterogêneas, eventualmente com áreas anecóides que correspondem às áreas de necrose (RIBEIRO; VENTURA; BARROS, 2002).

Muitas são as características ultra-sonográficas dos tumores intestinais. A grande dificuldade do exame ultra-sonográfico está em identificar o segmento intestinal envolvido. Para melhor determinar o local da lesão, são utilizados pontos de referência anatômicos (PENNINCK, 2002).

Um dos grandes diagnósticos diferenciais clínicos dos tumores intestinais são as lesões inflamatórias crônicas, uma vez que a sintomatologia clínica de ambos é muito semelhante: vômito, diarréia, melena, dor abdominal, perda de peso e letargia (HALL; SIMPSON, 2000). Parâmetros ultra-sonográficos como avaliação da espessura parietal intestinal, comprimento da lesão, integridade das camadas intestinais, envolvimento de linfonodos regionais e avaliação da motilidade intestinal podem auxiliar na diferenciação entre essas enfermidades (LAMB, 1999; PENNINCK, 1989).

Em pesquisa recente, Penninck et al. (2003) avaliaram o valor do exame ultra-sonográfico na diferenciação entre neoplasia intestinal e doença intestinal inflamatória crônica em 155 cães, dos quais 61 tinham enterite inflamatória e 89 tinham neoplasia intestinal. Os cães portadores de tumor intestinal apresentavam espessamento da parede $(1,5 \mathrm{~cm})$ significativamente maior do que aqueles que tinham enterite inflamatória $(0,6 \mathrm{~cm}) ; 99 \%$ dos cães portadores de neoplasia intestinal tinham perda da estratificação das camadas intestinais, enquanto $88 \%$ dos animais 
que tinham enterite inflamatória apresentavam estratificação normal das camadas, ou com leve alteração. Nas enterites, as alterações eram freqüentemente difusas. A análise multivariante realizada nesse estudo mostrou que a perda de estratificação das camadas intestinais como única característica tem um excelente valor preditivo na diferenciação das duas enfermidades. Entretanto, os autores ponderam que, embora o espessamento marcante da parede intestinal associado à perda da arquitetura das camadas pareça ser altamente sugestivo para neoplasia, pode ocorrer significativa variação em diferentes regiões geográficas, principalmente nos Estados Unidos, onde existe uma doença inflamatória intestinal incomum denominada pitiose. Nessa mesma investigação (PENNINCK et al., 2003), 89\% dos cães com enterite inflamatória tinham a arquitetura das camadas preservada ou com uma discreta redução - mas ainda visível -, e 11,4\% apresentavam perda da arquitetura das camadas. Os animais que se inseriam nesse último quadro, com perda significativa da arquitetura das camadas, a lesão inflamatória foi classificada histologicamente como severa, e apresentavam hemorragia, necrose ou enterite granulomatosa.

A pitiose é uma infecção crônica piogranulomatosa da parede intestinal ou da pele, causada por um organismo chamado Pythium insidiosum. Ao exame ultrasonográfico verifica-se marcante espessamento parietal associado à perda da estratificação das camadas intestinais, e linfonodomegalia mesentérica (GRAHAM et al., 2000).

Alguns casos de complicações de ovariossalpingo-histerectomia relacionados à formação de granuloma ao redor de segmentos de alças intestinais por fio de sutura não absorvível já foram descritos na literatura médico-veterinária. As cadelas apresentavam sinais clínicos e radiográficos de processo obstrutivo intestinal ou 
colônico; nos casos em que foi implementada a ultra-sonografia abdominal, foram observados: espessamento parietal focal significativo e perda de estratificação das camadas intestinais - parede levemente hipoecogênica. Pela característica sonográfica do segmento de alça intestinal acometido, não foi possível diferenciar entre granuloma e neoplasia intestinal (COOLMAN et al., 1999; LAMB, 2003).

O uso de Doppler nas patologias de vísceras ocas avalia a vascularização parietal em um segmento de alça patológico. Trabalhos recentes têm demonstrado que, frente a uma alça intestinal patológica, o estudo com Doppler colorido ou power Doppler pode diferenciar a natureza isquêmica da lesão. É importante salientar o Doppler não possibilita a diferenciação entre lesões inflamatórias e neoplásicas, visto que ambas geralmente cursam com aumento do fluxo parietal (RIBEIRO; VENTURA; BARROS, 2002).

\subsubsection{NEOPLASIAS DE ORIGEM PANCREÁTICA E ASPECTOS ULTRA-SONOGRÁFICOS}

As neoplasias pancreáticas podem ser divididas em pancreáticas epiteliais e não epiteliais. As neoplasias pancreáticas epiteliais ainda podem ser subdivididas, de acordo com a sua origem, em endócrinas e exócrinas (FRANCISCO NETO et al. 2002). Nos animais de companhia, a maior parte das neoplasias pancreáticas é de origem epitelial, o adenocarcinoma ductal ou acinar (WITHROW, 2001b). Os adenocarcinomas geralmente são tumores grandemente malignos, com alto índice de metástases em parede duodenal, fígado e linfonodos regionais no momento do diagnóstico, e menos comumente em pulmões (WILLIANS, 2000).

Aparentemente, existe uma correlação entre a incidência dessa neoplasia e o aumento da idade do animal, que normalmente acomete cães de meia idade. Não 
há predisposição sexual, embora alguns autores citem maior prevalência em fêmeas. Com relação à raça, airedele terrier, boxer, labrador retriever e cocker spaniel são mais predispostos ao desenvolvimento da moléstia (BENNETT et al., 2001; WITHROW, 2001b). Os sinais clínicos geralmente são pouco específicos, compreendem perda de peso, anorexia, depressão e vômito. Alguns animais podem apresentar ictéricia em decorrência da possível obstrução das vias biliares ou de metástases hepáticas (BENNETT et al., 2001). O exame físico também não traz achados específicos: a sensibilidade abdominal pode estar presente em virtude da pancreatite algumas vezes associada, e ocasionalmente verifica-se massa abdominal cranial à palpação (BENNETT et al., 2001; WITHROW, 2001b).

Os exames laboratoriais podem revelar aumento das enzimas pancreáticas, mas a evidência de obstrução biliar extra-hepática é mais evidente e relaciona-se ao aumento das enzimas hepáticas. O exame ultra-sonográfico pode ajudar a definir anormalidades pancreáticas, e o exame citológico do líquido peritoneal ou da massa pode revelar células neoplásicas (BENNETT et al., 2001; WILLIANS, 2000). Na maioria dos casos, o diagnóstico definitivo requer celiotomia exploratória, sendo imprescindível a biópsia para o exame histopatológico, pois, ao exame macroscópico, a pancreatite crônica e o carcinoma pancreático são semelhantes (WILLIANS, 2000).

Atualmente, o exame ultra-sonográfico é uma das principais modalidades de imagem utilizadas na avaliação do pâncreas em cães, por ser versátil, rápido e de fácil execução. Todavia, dentro da abordagem diagnóstica do abdome, o pâncreas é o órgão que exige, do examinador, maior habilidade e conhecimento da anatomia ultra-sonográfica, dado decorrente de suas relações topográficas. Acreditava-se que, na maioria dos casos, o pâncreas normal não fosse visível à ultra-sonografia, mas a 
introdução de novos equipamentos ultra-sonográficos, com alta resolução de imagem, possibilitou o aumento da freqüência de sua identificação nos cães (NYLAND et al., 2002b).

Embora essa técnica imaginológica tenha muitas vantagens, há que considerar as suas significativas limitações. A presença de gás ou bário no trato gastrintestinal pode interferir muito na identificação do parênquima, dificultando a boa avaliação da "zona pancreática". O preparo do animal é importante para melhor avaliação da região pancreática, mas, para pacientes que apresentam sinais de abdome agudo, poder-se-á abrir mão de qualquer preparo (NYLAND et al., 2002b). Outras limitações citadas são: dificuldade de avaliar o abdome minuciosamente em cães muito grandes e obesos, e tensão abdominal decorrente de dor ou medo do animal; nestes casos, o uso de analgesia ou sedação pode auxiliar o exame (LAMB et al., 1995).

Nyland et al. (2002b) lembram que o exame deve ser repetido se a primeira avaliação não permitir a elucidação diagnóstica, e ressaltam que a não verificação de anormalidades sonográficas na região pancreática não exclui completamente a presença de doença nesse órgão, pois existe a possibilidade de falsos negativos.

Ao exame ultra-sonográfico, o pâncreas é geralmente isoecóico a gordura abdominal ao redor, e é ocasionalmente visibilizado como uma estrutura fina e hipoecóica dorsal ou dorsomedial ao duodeno, ventral à veia porta e caudal ao estômago (NYLAND et al., 2002b).

Poucos estudos descreveram as características ultra-sonográficas dos tumores pancreáticos em cães. A presença de massa hipoecóica na região pancreática é sugestiva de neoplasia, entretanto, somente o exame sonográfico não é suficiente para diferenciar os processos neoplásicos de pancreatite, principalmente 
se for realizado uma única vez. A idade do animal, a história e os sinais clínicos e os exames laboratoriais devem ser considerados. Quando tratada de forma apropriada, é possível detectar a resolução da pancreatite nos exames ultra-sonográficos controles, diferentemente das neoplasias. O exame ultra-songráfico também não permite estabelecer o diagnóstico diferencial entre os tumores pancreáticos e a pancreatite crônica ou os abscessos pancreáticos (NYLAND et al., 2002b).

A presença de uma massa em região pancreática, associada a nódulos hepáticos, auxilia no estabelecimento de diagnóstico diferencial e no prognóstico. Áreas multifocais hipoecóicas ou hiperecóicas e lesões císticas podem estar presentes, dificultando a interpretação. A aparência sonográfica varia de acordo com a severidade e a cronicidade da doença (NYLAND et al., 2002b).

Devido ao alto potencial de malignidade do adenocarcinoma pancreático, usualmente, no momento do diagnóstico, o paciente já apresenta sinais de metástases hepáticas, carcinomatose abdominal e hemoperitônio, achados estes que podem auxiliar no diferencial diagnóstico (NYLAND et al., 2002b).

A realização de citologia aspirativa ecodirigida após a identificação da massa ao exame pode auxiliar no diagnóstico dos adenocarcinomas pancreáticos. O procedimento é simples e aparentemente sem complicações, todavia o citopatologista deve estar ciente da suspeita diagnóstica. A pancreatite é uma das complicações pós-biópsia ecodirigida que pode ocorrer devido à alta incidência desta enfermidade na espécie canina (BENNETT et al., 2001).

Em estudo retrospectivo realizado por Lamb et al. (1995), dos 16 casos de tumores pancreáticos analisados ultra-sonograficamente, 13 relacionavam-se a insulinoma, dois a metástases pancreáticas, e somente um animal apresentava tumor de origem exócrina. Nos casos de insulinoma, nódulos hipoecóicos lobulares 
ou esféricos relativamente pequenos foram visualizados - em quatro casos de insulinoma não foram detectadas alterações ultra-sonográficas: destes, em dois a alteração localizava-se no lobo pancreático direito, em um a alteração estava presente no lobo pancreático no esquerdo, e em um não foi determinada. O menor tumor detectado ao exame tinha $0,7 \mathrm{~cm}$, e estava localizado na porção cranial do lobo pancreático direito. Em seis dos 16 casos, a origem da massa foi descrita como "provável massa pancreática": destes, em três animais a origem era incerta, porque as bordas do pâncreas não estavam bem definidas ao exame.

Com relação às neoplasias do pâncreas endócrino no cão, o insulinoma é o mais comum e freqüentemente maligno. Seus sinais clínicos são convulsões, fraqueza ou desmaios decorrentes da hipoglicemia (DUNN et al., 1993). O diagnóstico não cirúrgico desse tumor é difícil, mas os sintomas causados pela hipoglicemia, associados à hiperinsulinemia orgânica, fornecem o diagnóstico (DUNN et al., 1993). Como citado anteriormente, o insulinoma pode aparecer ultrasonograficamente como nódulos redondos ou lobulares, mas pode ser muito difícil detectar esses nódulos no lobo pancreático esquerdo, pois a sensibilidade do ultrasom é muito baixa nesse diagnóstico (LAMB et al., 1995).

Gonzalez (2002) estudou o emprego da ultra-sonografia ambulatorial em casos de abdome agudo no cão. Dentre 4 pacientes com massas pancreáticas, a ultra-sonografia ambulatorial indicou corretamente a presença de massa sugestiva de neoplasia em apenas um caso. Os achados ultra-sonográficos foram de massa pancreática heterogênea, arredondada, irregular, espessamento e pregueamento duodenal, nódulos hepáticos focais hipoecóicos, hemoperitônio e hiperecogenicidade mesentérica generalizada. O diagnóstico histológico foi de adenocarcinoma pancreático. 
Na medicina, o adenocarcinoma pancreático ductal representa cerca de $90 \%$ de todas as neoplasias pancreáticas. Aproximadamente dois terços dos pacientes acometidos por essa moléstia apresentam invasão locorregional pela neoplasia quando manifestam sintomatologia clínica, e cerca de $85 \%$ já se encontram em estado metastático. Os sítios metastáticos mais comuns são os linfonodos peripancreáticos, gástricos, mesentéricos, omentais e porto-hepáticos -, o fígado, os pulmões, o peritônio e as adrenais (FRANCISCO NETO et al., 2002.).

Os achados sonográficos são classificados em diretos e indiretos. Os sinais diretos são: massas sólidas hipoecóicas, homogêneas ou heterogêneas, de contornos imprecisos, localizadas no pâncreas. Tais massas podem estar restritas aos limites da glândula, ou determinar aumento das suas dimensões, com compressão das estruturas vizinhas. Em algumas ocasiões, a lesão pode ser isoecóica ao parênquima pancreático. Pequenas áreas centrais de liqüefação representando necrose são um achado ecográfico pouco freqüente; em geral, podem ser facilmente diferenciadas de outras lesões císticas pancreáticas, por seus contornos irregulares, paredes espessas e conteúdo heterogêneo. Entretanto, pseudocistos podem ser encontrados a montante da lesão neoplásica (FRANCISCO NETO et al., 2002). Quando são considerados apenas achados por imagem, a neoplasia difusamente infiltrativa pode ser confundida com a pancreatite aguda. $\mathrm{O}$ aspecto lobulado da lesão, associado à ausência de sinais inflamatórios nos tecidos adjacentes e à história clínica, pode auxiliar na diferenciação (FRANCISCO NETO et al., 2002).

Com relação aos sinais indiretos, há que se mencionar a dilatação do ducto pancreático pois, nos processos obstrutivos pancreáticos, o ducto torna-se dilatado, assume forma biconvexa, trajeto tortuoso e apresenta afilamento abrupto do seu 
calibre. No entanto, a diferenciação entre doenças neoplásicas e inflamatórias (pancreatite) pode ser muito difícil. Diz-se que, se o diâmetro do ducto de Wirsung ultrapassar a metade da espessura do parênquima pancreático, a etiologia mais provável é neoplásica (FRANCISCO NETO et al., 2002). Outro sinal indireto das neoplasias da cabeça pancreática é a dilatação das vias biliares. A obstrução ocorre no colédoco, ou seja, após a junção entre o ducto hepático comum e o cístico, havendo dilatações das vias biliares intra-hepáticas, do cístico, da vesícula biliar e do próprio colédoco. A bile espessa e os microcálculos podem ser achados adicionais. A redução abrupta do calibre do ducto biliar é fortemente sugestiva de malignidade, diferentemente das lesões benignas, nas quais ocorre afilamento gradual (FRANCISCO NETO et al., 2002).

Com relação ao estadiamento, a avaliação das estruturas vasculares peripancreáticas deve ser feita de forma minuciosa, incluindo o tronco celíaco, artéria e veia mesentéricas superiores, veia porta e veia esplênica. Geralmente, é difícil a diferenciação precisa entre compressão e invasão de estruturas venosas. A deformidade dos contornos e a perda dos planos gordurosos sugerem invasão tumoral. A presença de circulação colateral peripancreática constitui-se em forte indicativo de comprometimento vascular. O encarceramento do tronco celíaco ou da artéria mesentérica superior pode ocorrer por extensão direta da neoplasia, ou por envolvimento linfonodal (FRANCISCO NETO et al., 2002).

As estruturas vasculares podem ser melhor avaliadas com o uso do Doppler colorido (FRANCISCO NETO et al., 2002), que apresentou sensibilidade de $89,9 \%$, especificidade de $95,8 \%$ e acurácia de $84,1 \%$ na detecção do envolvimento vascular no adenocarcinoma pancreático em investigação realizada com 26 pacientes. Assim, o Doppler colorido aparentemente tem uma boa acurácia na 
preleção e identificação de carcinomas pancreáticos não ressecáveis (ISHIDA et al., 1999)

No homem, o insulinoma é uma neoplasia rara, porém é o tumor endócrinopancreático mais freqüente. Os insulinomas são tumores geralmente solitários e pequenos, medindo até $2 \mathrm{~cm}$ em $66 \%$ dos casos, e menos de $1 \mathrm{~cm}$ em $24 \%$ dos casos. O diagnóstico é realizado com base nos sintomas causados pela hipoglicemia associada à hiperinsulinemia orgânica. A ressecção cirúrgica é o tratamento de escolha. Para facilitar tal procedimento, estudos de imagem como a ultra-sonografia abdominal e endoscópica, a tomografia computadorizada e, mais recentemente, a ressonância magnética, têm sido utilizadas. Aproximadamente 20 a $60 \%$ dos insulinomas não podem ser localizados em estudos pré-operatórios de imagem e, em 10 a $20 \%$ dos pacientes com insulinoma, a exploração cirúrgica falha em localizar o tumor (SILVEIRA et al., 2002).

A ultra-sonografia intra-operatória tem mostrado resultados satisfatórios na localização de insulinomas pancreáticos, evitando ressecções complexas e desnecessárias, com sensível redução no número de complicações cirúrgicas (SILVEIRA et al., 2002).

Do exposto, verifica-se que as dificuldades encontradas durante o exame ultra-sonográfico quando da suspeita de neoplasias pancreáticas em cães são várias, como a habilidade de determinar a origem da neoplasia - dependente da posição e da morfologia -, pois o lobo caudado do fígado e as alterações em linfonodos mesentéricos adjacentes ao pâncreas podem ser confundidos; distinção entre as pancreatites e as neoplasias pancreáticas, já que cães com pancreatite severa podem ter lesões com aspecto de massas hipoecóicas ou hiperecóicas, líqüido livre abdominal localizado e aumento de linfonodo peripancreático adjacente, 
assim como nas neoplasias; aparência similar entre os linfonodos peripancreáticos patológicos - pequenos, arredondados e hipoecóicos - e os nódulos de insulinoma, que também podem causar erros de interpretação (LAMB et al., 1995). 
3 Material e Método 


\section{MATERIAL E MÉTODO}

\subsection{MATERIAL}

Foram atendidos no período de outubro de 2002 a outubro de 2003 e encaminhados ao Serviço de Diagnóstico por imagem (ultra-sonografia) do Hospital Veterinário da Faculdade de Medicina Veterinária e Zootecnia da Universidade de São Paulo.

\subsubsection{PACIENTES}

Considerou-se a avaliação de cães de quaisquer idade e sexo, com ou sem raça definida (CRD/SRD), que atendessem aos critérios estabelecidos para a inclusão de casos, totalizando 165 cães.

\subsubsection{CRITÉRIOS DE INCLUSÃo}

Pacientes com histórico, sinais clínicos e exame físico - únicos ou em associação - de hiporexia/anorexia, aumento de volume abdominal, presença de massa abdominal à palpação, diarréia, vômito e outros sinais pouco específicos, para os quais o médico veterinário responsável julgasse necessário e solicitasse o exame ultra-sonográfico, como parte da conduta diagnóstica, para possível detecção ou descarte de neoplasia abdominal.

\subsubsection{CRITÉRIOS DE EXCLUSÃo}

Pacientes para os quais não tenha sido possível o acompanhamento até a obtenção do diagnóstico definitivo, citológico, cirúrgico-histopatológico ou necroscópico-histopatológico. 
Este estudo foi submetido à avaliação e aprovado pela Comissão de Bioética da Faculdade de Medicina Veterinária e Zootecnia da Universidade de São Paulo.

\subsubsection{EQUIPAMENTOS}

\section{Ultra-sonografia}

Aparelho de ultra-sonografia dinâmico, bidimensional - Modelo HDI-5000*, marca ATL - Philips Ultrasound, com transdutores eletrônicos convexos e lineares, variando de 2,0 a 12,0 MHz, de acordo com o porte do animal e o órgão a ser avaliado.

A documentação fotográfica dos exames foi implementada em impressoras de vídeo em cores Mitisubishi CP700* e vídeo preto e branco Sony UP 895MD *.

\section{Equipamentos de Biópsia}

O material utilizado para as punções aspirativas por agulha fina (PAAF) foi um dispositivo de pressão negativa acoplado a uma seringa de uso convencional (10ml), agulha fina hipodérmica $(20$ × 5,5mm) ou mandril metálico de cateter endoflébico $22 \mathrm{~g}$ ou $24 \mathrm{~g}$, lâminas.

Para coleta de fragmento para exame histológico foi utilizado agulha Tru-cut ${ }^{1}$, acopladas a pistola automática Biopty $\mathrm{Gun}^{2}$.

\subsection{MÉTODO}

\subsubsection{TÉCNICA DE EXAME ULTRA-SONOGRÁFICO}

O exame foi realizado após ampla tricotomia do abdome ventral entre a região epigástrica e a região hipogástrica, compreendida entre o apêndice xifóide e os dois últimos pares de glândulas mamárias, estendendo-se bilateralmente a região dorsal. O animal foi posicionado em decúbito dorsal, do lado direito do examinador, com a 
região cefálica paralela ao aparelho, e a região caudal próxima ao lado direito do examinador.

O exame seguiu um método pré-estabelecido quanto à seqüência e ao detalhamento das características ultra-sonográficas. O equipamento e o operador foram os mesmos para todos os pacientes.

Os exames foram realizados com o paciente em decúbito dorsal, sobre calha de espuma, sempre que as condições clínicas permitissem. Em pacientes com dificuldade respiratória ou grande distensão abdominal empregou-se os decúbitos lateral direito e esquerdo para maior conforto respiratório. Toda a cavidade abdominal foi examinada em todos os pacientes, sem que o exame tenha sido direcionado pela suspeita clínica, presença da massa ou por pontos dolorosos previamente detectados, respeitando-se sempre a mesma seqüência de exame.

O exame sempre foi iniciado na região do quadrante cranial médio (xifóide) e varreu-se toda a cavidade no sentido horário. A seqüência dos órgãos abdominais avaliados foi: fígado, - vesícula biliar -, estômago, baço, rim esquerdo, região ovariana esquerda, adrenal esquerda, bexiga, próstata ou região uterina, região de linfonodos ilíacos mediais, alças intestinais, rim direito, região de ovário direito, adrenal direita, duodeno, região pancreática e região de linfonodos mesentéricos peri-portais. Além da avaliação cuidadosa de todos os órgãos, se examinava a região dos recessos: hepato-renal, espleno-renal e recessos vesico-uterino ou vesico-prostático para a possível detecção de fluido abdominal livre.

Quando na presença de massas muito grandes, inicialmente, se avaliavam as características ultra-sonográficas da massa e após tentava-se localizar a origem (órgão) por meio de exclusão dos órgãos normais detectados durante o exame. 
A interpretação ultra-sonográfica bidimensional foi realizada durante o exame, pela observação dinâmica das alterações; os achados sonográficos e a impressão diagnóstica foram anotados em fichas próprias. As lesões foram categorizadas durante o exame como: benigna, maligna e impossível de determinar. Quando o temperamento do paciente o permitia, foram realizados exames com o Doppler colorido ou Power Doppler, para verificar se os achados auxiliavam na categorização de malignidade.

As avaliações com Doppler colorido ou Power Doppler foram realizadas após minucioso exame em modo bidimensional e localização da lesão.

Avaliou-se pelo mapeamento com Doppler colorido e Power Doppler a presença ou ausência de fluxo sangüíneo intralesional, que pudessem sugerir neoângiogenese tumoral.

A Análise Doppler foi realizada com filtro médio a baixo e com PRF - ("Pulse repetition frequency") - variando de 700 a $1500 \mathrm{~Hz}$.

\subsubsection{CONDUTA CLÍNICA}

Os laudos ultra-sonográficos foram apresentados ao clínico que foi o responsável pela escolha dos procedimentos diagnósticos adicionais (laboratoriais, biópsias aspirativas ou por fragmento eco-dirigidas e decisão terapêutica tratamento médico e/ou cirúrgico).

\subsubsection{EXECUÇÃO DAS BIÓPSIAS}

Os critérios para a realização das biópsias por fragmento ou punção aspirativa por agulha fina (PAAF) foram: condições do paciente, características sonográficas da lesão, recomendação clínica e consentimento do proprietário. 
As punções aspirativas e/ou biópsias por fragmento foram realizadas pelo mesmo ultra-sonografista, quase sempre no mesmo dia e logo após o exame ultrasonográfico; nos animais inquietos foi realizada sedação e/ou anestesia geral intravenosa.

Em todos os pacientes submetidos a biópsia por fragmento foi requerido a anestesia geral.

As punções foram realizadas com o paciente em decúbito dorsal, este colocado sobre uma calha de espuma. Após sua introdução na pele, a agulha era direcionada para o interior da lesão com a orientação ultra-sonográfica. Uma vez no local desejado, obtia-se o material por meio da criação de pressão negativa e de movimentos rápidos e firmes da agulha em várias direções no caso da PAAF, ou por disparo da pistola Biopty no caso da biópsia por fragmento.

O aspirado foi enviado para análise citológica na forma de esfregaços em lâminas, o fragmento histopatológico foi colocado em um frasco com formol a $10 \%$, para ser processado e emblocado em parafina.

\subsubsection{Exame Anatomopatologico}

As lâminas de citologia, espécimes obtidas por biópsia de fragmento, espécimes obtidas por celiotomia foram encaminhados ao serviço de Patologia Animal da Faculdade de Medicina Veterinária e Zootecnia de São Paulo e processados para o estudo, assim como os cadáveres.

As lâminas de citologia foram processadas e interpretadas conforme a classificada seguindo as descrições de Baker e Lumsden (2000).

Os exames histopatológicos das lesões foram analisados conforme a classificação de Meuten (2002). 


\subsubsection{ESTUDO DA CONTRIBUIÇÃO DIAGNÓSTICA DA ULTRA-SONOGRAFIA NAS NEOPLASIAS ABDOMINAIS}

Com o objetivo de estudar a contribuição diagnóstica sonográfica em pacientes com suspeita de processos neoplásicos abdominais, o diagnóstico ultrasonográfico foi comparado ao diagnóstico final de cada um dos pacientes.

Empregou-se o estudo da acurácia, ou eficiência diagnóstica, de acordo com o nível 2 de avaliação de testes diagnósticos de imagem por Fryback e Thornbury (1991), ou seja, comparando-se com o diagnóstico final.

\section{Diagnóstico final (Padrão-ouro)}

Todos os pacientes incluídos na presente investigação foram acompanhados até o estabelecimento de um diagnóstico final, pelos métodos citológico, cirúrgicohistopatológico e necroscópico-histopatológico.

Em um animal, no qual foi excluído o processo neoplásico abdominal - na suspeita de neoplasia hepática -, o padrão ouro foi clínico, "construído" por meio da história, exame físico, exames laboratoriais, exame radiográfico e ecocardiográfico que suportavam um diagnóstico final.

Todas as cirurgias e necropsias dos pacientes estudados foram acompanhadas, com finalidade ilustrativa e de documentação; os achados relevantes foram fotografados. 


\subsubsection{ANÁlisE dos RESULTADOS}

Inicialmente, foi determinada a presença ou a ausência de massa abdominal; posteriormente, avaliou-se a capacidade do exame ultra-sonográfico em indicar a origem do órgão abdominal envolvido pelo processo neoplásico.

\subsubsection{INTERPRETAÇÃO DAS IMAGENS ULTRA-SONOGRÁFICAS CONVENCIONAIS}

Foram determinadas e descritas as características ultra-sonográficas dos diferentes tipos de lesões - neoplásicas e não neoplásicas - no fígado, nas alças intestinais e no pâncreas.

Em relação à ecotextura, as lesôes foram classificadas como focais, multifocais ou difusas.

A determinação da malignidade foi estabelecida por meio dos aspectos sonográficos, sendo que esta indicação de malignidade foi determinada ao final do exame e comparada com o diagnóstico final.

As lesões difusas foram caracterizadas como aumento ou diminuição da ecogenicidade do órgão em estudo. As lesões focais ou multifocais foram caracterizadas, com relação à ecogenicidade, como: nódulos hipoecóicos, hiperecóicos, mistos - heterogêneos -, em "alvo", cavitários (lesões císticas com parede irregulares, com presença ou não de septações). As lesões focais ou multifocais foram classificadas em três grupos adaptadas da classificação de Blanco (2000):

Tipo I: Alterações focais ou multifocais de contorno regular e aspecto homogêneo baixa complexidade;

Tipo II: Alterações focais ou multifocais de contorno irregular, hipocóicas, hiperecóicas ou em "alvo" - média complexidade; 
Tipo III: Alterações focais ou multifocais de ecogenicidade mista - heterogênea -, nódulos em "alvo", nódulos cavitários com microcalcificações ou calcificações, e que alteram o contorno e/ou a cápsula do órgão - alta complexidade.

Lesões do tipo II associadas a linfonodomegalia mesentérica, ascite ou alteração sonográfica em outro órgão, ou lesões do tipo III, foram consideradas suspeitas de neoplasias hepática ou pancreática maligna.

Na avaliação do trato gastrintestinal - estômago e alças intestinais -, foram verificadas: a espessura da parede, a perda de estratificação das camadas, o grau de ecogenicidade - hipoecóica, hiperecóica ou mista - e a característica da lesão no corte transversal - circunferencial simétrica ou assimétrica. Estas características foram determinadas e descritas.

Foram considerados malignos os segmentos gastrintestinais que tivessem aumento na espessura da parede, - maior que $5 \mathrm{~mm}$ - , associado à perda de estratificação das camadas parietais.

\subsubsection{INTERPRETAÇÃO DO DOPPLER COLORIDO PARA O ESTUDO DA VASCULARIZAÇÃO TUMORAL}

Os resultados da análise do Doppler foram categorizados dependendo da presença ou não de sinais vasculares e do tipo de vascularização e foram classificados de acordo com o proposto por Tanaka et al. (1990):

Padrão I: Ausência de vascularização ao Doppler

Padrão II: Presença de vascularização periférica ao Doppler

Padrão III: Presença de vascularização central e periférica ao Doppler

Padrão IV: Presença de vascularização central ao Doppler

Foram consideradas malignas as lesões que tivessem padrões III ou IV. 
A ausência de fluxo somente foi caracterizada após vasta exploração, com o Doppler colorido, de todas as áreas do tumor.

Os dados relativos à distribuição de freqüências segundo o sexo, a condição racial, a faixa etária, os sinais clínicos e a origem da neoplasia também foram analisados e serão apresentados.

As características ultra-sonográficas bidimensionais e mapeamento do Doppler colorido serão analisados de forma descritiva e correlacionadas aos resultados citológicos e/ou cirúrgicos/necroscópicos (macroscópicos) em conjunto com o exame histopatológico. 
4 RESULTADOS 


\section{RESULTADOS GERAIS}

Dos 165 cães avaliados, 114 cães se apresentavam dentro dos critérios préestabelecidos para o estudo, desses $88(77,1 \%)$ eram portadores de neoplasias abdominais. Destes 88 casos de processo neoplásico abdominal, 85 (96,5\%) foram classificados como neoplasia maligna, e três (3,5\%) como neoplasia benigna.

Com o método ultra-sonográfico o órgão abdominal (origem) acometido pela massa abdominal foi - corretamente classificada em $84(95,4 \%)$ cães, erroneamente classificados em $3(3,5 \%)$ cães e não identificada em 1 (1,1\%) cão (Tabela 1$)$.

Tabela 1- Número de casos (n.) e respectivas porcentagens (\%) na identificação correta, incorreta ou indeterminada, na origem da massa abdominal por meio do exame ultra-sonográfico, dos 88 cães com diagnóstico de neoplasias abdominais, atendidos no Serviço de diagnóstico por imagem (ultra-sonografia) do HOVET-FMVZ-USP, - São Paulo - out. 2002 - out. 2003

\begin{tabular}{lcc}
\hline \hline $\begin{array}{c}\text { Determinação ultra-sonográfica da origem } \\
\text { da massa }\end{array}$ & Número de casos & $\mathbf{f ( \% )}$ \\
\hline \hline Identificação correta & 84 & 95,4 \\
Identificação incorreta & 3 & 3,5 \\
Não Identificada & 1 & 1,1 \\
\hline \hline Total & $\mathbf{8 8}$ & $\mathbf{1 0 0 \%}$ \\
\hline \hline
\end{tabular}

Os casos em que houve erro na classificação da origem da massa foram:

1- massa de origem ovariana classificada como de origem esplênica, sendo esta de grande extensão, ecogênica e com áreas císticas/cavitárias em seu interior, o animal também apresentava líquido livre abdominal e aumento de cornos uterinos. 
2- massa de origem intestinal classificada como de origem ovariana, esta localizada em região hipomesogástrica e com característica cística. O animal também apresentava líquido livre abdominal e aumento de cornos uterinos.

3- massa de origem pancreática caracterizada como de origem de linfonodo mesentérico, esta localizada em região hipogástrica.

Em um caso a origem da massa não foi determinada pelo exame sonográfico, sendo que esta foi posteriormente determinada como massa esplênica pela celiotomia exploratória. A porção esplênica visibilizada ao exame sonográfico apresentava-se dentro dos critérios de normalidade, o animal ainda apresentava grande distensão gástrica gasosa e líquido livre abdominal.

\subsection{ORIGEM HEPÁTICA}

Dos 114 cães que se apresentavam dentro dos critérios de inclusão, em 15 animais foi aventada a suspeita de processo neoplásico de origem hepática. Destes com suspeita de neoplasias hepáticas, 12 realmente estavam relacionados a tumor hepático, enquanto em três esta possibilidade diagnóstica foi excluída por meio do exame sonográfico abdominal. Dos 12 casos de tumores hepáticos diagnosticados, 11 eram neoplasias malignas e somente um caso revelou-se como neoplasia benigna.

Os pacientes com neoplasias hepáticas apresentaram a seguinte distribuição: $8(66,6 \%)$ machos e $4(33,4 \%)$ fêmeas, $5(41,6 \%)$ cães SRD e 7(58,4\%) cães CRD, com faixa etária entre 3 e 16 anos, e mediana igual a 10,5 anos. 
Os sinais clínicos mais freqüentes foram: anorexia (8), massa hepática ou hepatomegalia à palpação (7), icterícia (5), perda de peso (5), distensão abdominal fluida (4), prostração (3), diarréia (2) e dispnéia (2).

Os tipos cito-histológicos diagnosticados foram: colangiocarcinoma 6 (50\%), carcinoma hepatocelular $3(25,1 \%)$, tumor de células mesenquimais hemangiossarcoma - 1 (8,3\%), linfoma de pequenas células $1(8,3 \%)$ e cistoadenoma de vias biliares 1 (8,3\%) (Tabela 2).

Tabela 2 - Número de casos (n.) e respectivas porcentagens (\%) dos tipos citohistológicos tumorais dos 12 cães com diagnóstico de neoplasias hepáticas, atendidos no Serviço de diagnóstico por imagem (ultrasonografia) do HOVET-FMVZ-USP, - São Paulo - out. 2002 - out. 2003

\begin{tabular}{lcc}
\hline \hline \multicolumn{1}{c}{ Neoplasias hepáticas } & Número & f.(\%) \\
\hline \hline Malignas & & \\
Colangiocarcinoma & 6 & 50 \\
Carcinoma hepatocelular & 3 & 25,1 \\
$\quad$ Tumor de células mesenquimais - HSA & 1 & 8,3 \\
$\quad$ Linfoma pequenas células & 1 & 8,3 \\
Benignas & 1 & 8,3 \\
$\quad$ Cistoadenoma de vias biliares & 12 & 100 \\
\hline \hline Total & 12 \\
\hline \hline
\end{tabular}

Os métodos de diagnóstico definitivo empregados foram: necroscópicohistopatológico 8 (75\%), citológico $2(16 \%)$ e cirúrgico-histopatológico 1 (9\%). (Quadro 1).

As características ultra-sonográficas dos 6 cães com colangiocarcinoma foram: parênquima aumentado de tamanho com contorno irregular (6), nódulos cavitários complexos - ou seja, com septações internas - associados a nódulos em "alvo" (5); parênquima hepático heterogêneo apresentando nódulos hiperecóicos e em "alvo" (1). Em todos os animais foram identificados nódulos em "alvo" e linfonodomegalia regional. Também foram observados líquido livre abdominal (4), 
nódulos hipoecóicos em baço (3) e severo espessamento da parede duodenal com perda de estratificação de camadas (1). O diâmetro dos nódulos complexos variou de $4,0 \mathrm{~cm}$ a $9,45 \mathrm{~cm}$.

Nos 3 cães com carcinoma hepático, os aspectos ultra-sonográficos foram: parênquima aumentado de tamanho com contorno irregular (3), nódulos hiperecóicos maiores associados a múltiplos nódulos em "alvo" - estes nódulos de contorno irregular (2); nódulos hiperecóicos de contornos irregulares (1). Em todos os animais, o fígado tinha o aspecto de padrão "mosaico". Foram observados linfonodomegalia regional (2) e nódulos em "alvo" no parênquima esplênico (1). A variação de diâmetro dos nódulos foi de 1,3 a 3,0 cm.

No cão com diagnóstico de hemangiossarcoma hepático, as características ultra-sonográficas presentes foram: hepatomegalia com contorno irregular, micronódulos multifocais irregulares, e nódulos hiperecóicos e hipoecóicos maiores. Verificou-se também linfonodomegalia regional. Os nódulos maiores apresentavam diâmetro de $1,5 \mathrm{~cm}$.

No cão com diagnóstico de linfoma hepático de pequenas células, foram visualizados os seguintes aspectos ultra-sonográficos: hepatomegalia de contorno irregular, múltiplos nódulos hipoecóicos do tipo "mosaico", e ainda lesão focal em alça intestinal com severo espessamento de parede e perda de estratificação de camadas. Os nódulos maiores apresentavam diâmetro de 4,5cm.

No cão com diagnóstico de cistoadenoma de vias biliares, os aspectos ultrasonográficos constatados foram: hepatomegalia de contorno arredondado e múltiplos nódulos hipoecóicos, cujo diâmetro variou de 1,0cm a 5,0cm. (Quadro 1). 
O diâmetro dos nódulos hepáticos variou de $1,0 \mathrm{~cm}$ a $9,4 \mathrm{~cm}$ o menor. A tabela 3 apresentam os tipos histológicos dos tumores, a freqüência destes, e o tamanho dos nódulos presentes nos cães estudados.

Tabela 3 - Tipos histológicos dos tumores e sua freqüência (f), e tamanho dos nódulos dos cães com diagnóstico confirmado de neoplasia hepática atendidos no Serviço de diagnóstico por imagem (ultra-sonografia) do HOVET-FMVZ-USP - São Paulo - out. 2002 - out. 2003

\begin{tabular}{lcccc}
\hline \hline \multicolumn{1}{c}{ Tipos histopatológicos } & $\mathbf{f . ( \% )}$ & \multicolumn{2}{c}{ Diâmetro (cm) } & \multirow{2}{*}{$\mathbf{6 , 0}$} \\
\cline { 3 - 4 } & & $\mathbf{0 , 1 - 3 , 0}$ & $\mathbf{3 , 1 - 6 , 0}$ & \\
\hline \hline Colangiocarcinoma & $6(50,0 \%)$ & - & 2 & 4 \\
Carcinoma hepatocelular & $3(25,1 \%)$ & 2 & 1 & - \\
Hemangiossarcoma & $1(8,3 \%)$ & 1 & - & - \\
Linfoma de peq. céls & $1(8,3 \%)$ & 1 & - & - \\
Cistodenoma de vias biliares & $1(8,3 \%)$ & - & 1 & - \\
\hline \hline
\end{tabular}

O quadro 1 demonstra as características ultra-sonográficas do parênquima hepático, outras alterações da cavidade abdominal, o método diagnóstico e a conclusão diagnóstica dos casos de neoplasias hepáticas.

Com relação a suspeita de tumores hepáticos baseados na ultra-sonografia convencional, e de acordo com os critérios pré-estabelecidos neste trabalho para a diferenciação entre tumores hepáticos benignos e malignos, 11 casos $(100 \%)$ suspeitos de malignidade foram confirmados ao exame citológico ou anatomopatologicamente. Contudo, parâmetros suspeitos para malignidade também foram observados em um caso de tumor benigno (cistoadenoma de vias biliares). A tabela 4 demonstra esses achados. 
Tabela 4 - Distribuição conjunta do padrão ecotextural (USG) dos tumores pela natureza dos mesmos, dos 12 cães com neoplasias hepáticas atendidos no Serviço de diagnóstico por imagem (ultra-sonografia) do HOVETFMVZ-USP, segundo a origem da lesão - São Paulo - out. 2002 - out. 2003

\begin{tabular}{ccc}
\hline \hline USG & Benignas & Malignas \\
\hline \hline Tipo I & - & - \\
Tipo II & $1(1+)$ & $5(5+)$ \\
Tipo III & - & $6(6+)$ \\
\hline \hline Total & 1 & 11 \\
\hline \hline
\end{tabular}

Tipo I: Lesões focais ou multifocais de contorno regular (hipoecóicas ou hiperecóicas) em somente um órgão abdominal.

Tipo II: Alterações focais ou multifocais de contornos irregulares, hipoecóicas, hiperecóicas ou em "alvo" (média complexidade).

Tipo III: Alterações focais ou multifocais de ecogenicidade mista (heterogênea), nódulo em "alvo", nódulos cavitários, com microcalcificações ou calcificações, que alteram o contorno e/ou a cápsula do órgão (alta complexidade)

+ : $\quad$ representa alterações em outros órgãos, linfonodomegalia adjacente e/ou ascite.

Em 3 cães com suspeita de tumores hepáticos, o exame ultra-sonográfico descartou esta possibilidade diagnóstica. Os diagnósticos destes cães foram: hepatopatia crônica, cirrose hepática e hepatomegalia por congestão. A descrição dos achados ultra-sonográficos do fígado e outras alterações detectáveis no abdome, os métodos diagnósticos e os diagnósticos são apresentados no quadro 2.

\subsection{ORIGEM INTESTINAL}

A suspeita de processos neoplásicos de origem intestinal compreendeu 12 casos dos 114 que se apresentavam dentro dos critérios pré-estabelecidos. Destes, 8 casos foram confirmados neoplasia, e em 4 foi excluída essa possibilidade 
diagnóstica. Dos 8 casos de tumores intestinais diagnosticados, 7 eram neoplasias malignas e 1 benigna.

Com relação ao sexo, à raça e à idade, os pacientes com neoplasias intestinais apresentaram a seguinte distribuição: 6 (75\%) eram fêmeas e 2 (25\%) eram machos; 2 (25\%) cães SRD e 6 (75\%) cães CRD, com faixa etária entre 6 e 14 anos e mediana igual a 8,5 anos.

Os sinais clínicos mais freqüentes foram: hiporexia/anorexia (5), prostração (4), perda de peso (4), vômito e diarréria (3), vômito (2), aumento de volume abdominal (2), diarréia (1), disquesia e tenesmo (1) e dispnéia (1).

Os tipos diagnósticos cito-histopatológicos foram: adenocarcinoma intestinal 2(25\%), linfoma do trato digestório $2(25 \%)$, leiomiossarcoma intestinal $2(25 \%)$, tumor de células mesenquimais 1 (12,5\%), adenoma de cólon 1 (12,5\%). Estes dados estão representados na tabela 5 .

Tabela 5 - Número de casos (n.) e respectivas porcentagens (\%) dos tipos citohistológicos tumorais dos 8 cães com diagnóstico de neoplasias intestinais, atendidos no Serviço de diagnóstico por imagem (ultrasonografia) do HOVET-FMVZ-USP, - São Paulo - out. 2002 - out. 2003

\begin{tabular}{lcc}
\hline \hline \multicolumn{1}{c}{ Neoplasias intestinais } & Número & f.(\%) \\
\hline \hline Malignas & & \\
Adenocarcinoma & 2 & 25 \\
Linfoma do trato digestório & 2 & 25 \\
$\quad$ Leiomiossarcoma & 2 & 25 \\
$\quad$ Tumor de células mesenquimais & 1 & 12,5 \\
Benignas & 1 & 12,5 \\
$\quad$ Adenoma de cólon & 1 & 100 \\
\hline \hline Total & & \\
\hline \hline
\end{tabular}


Os métodos de diagnóstico definitivo empregados foram: cirúrgicohistopatológico 4(50\%), necroscópico-histopatológico 2(25\%), e citologia aspirativa 2(25\%). Estes dados estão representados no quadro 3.

Nos dois casos de adenocarcinoma intestinal (2), a ultra-sonografia revelou espessamento parietal transmural assimétrico. Em um dos cães, esse espessamento localizava-se em 2 pontos distintos, de pequena extensão e hipoecóicos; o outro cão apresentava um espessamento parietal ecogênico e heterogêneo de grande extensão. Houve perda de estratificação das camadas parietais e sinais de processo obstrutivo intestinal em ambos os casos. Em um dos animais foi possível localizar o segmento intestinal acometido, região íleo-cecal. A espessura parietal variou de 0,8 a $1,3 \mathrm{~cm}$.

Outros achados ultra-sonográficos detectados na cavidade abdominal foram: esplenomegalia com nódulos hipoecóicos ou hiperecóicos (2), linfonodomegalia mesentérica (2) e efusão peritoneal (1).

Nos casos de linfoma do trato digestório (2), as características ultrasonográficas observadas foram diferentes. Em um caso foi verificado espessamento focal, transmural, simétrico da parede intestinal de aspecto em "alvo" ao corte transversal, linfonodomegalia mesentérica e esplenomegalia. No outro caso, foi verificada a característica infiltrativa com espessamento difuso da parede, associada a linfonodomegalia mesentérica. Em ambos os animais houve perda da estratificação das camadas parietais. O espessamento parietal variou de 0,9 a $1,6 \mathrm{~cm}$.

Nos dois casos de leiomiossarcoma intestinal diagnosticados, foram visibilizadas ultra-sonograficamente massas parietais extrínsecas, assimétricas e de ecogenicidade mista (apresentando áreas hipo/anecóicas centrais), com 
mensurações variando de 3,5 a $4,5 \mathrm{~cm}$. Em ambos os casos houve perda de estratificação das camadas parietais. Nos dois animais foi possível identificar, sonograficamente, linfonodomegalia mesentérica. Nódulos em "alvo" irregulares no fígado, nódulos hipoecóicos no baço e efusão peritoneal também foram detectados em um caso (Quadro 3).

Em um caso de neoplasia intestinal diagnosticada como tumor de células mesenquimais, a massa foi erroneamente classificada como de origem ovariana por meio do exame ultra-sonográfico. Essa massa apresentava contornos assimétricos, de ecogenicidade mista e com áreas anecóicas periféricas, e estava localizada em região meso-hipogástrica abdominal, caudal ao rim esquerdo. O tamanho da massa era de 2,9 a $3,3 \mathrm{~cm}$. Outros achados ultra-sonográficos detectados na cavidade abdominal foram: aumento uterino em região de corpo, ovário policístico direito e efusão peritoneal.

No caso de adenoma de cólon descendente, a ultra-sonografia revelou massas sólidas, ecogênicas, de contorno regular (aspecto de nódulos), invadindo e causando estreitamento luminal. Também foi observada uma transição abrupta entre o segmento normal e a região dos nódulos. Houve perda parcial da estratificação das camadas parietais. O tamanho dos nódulos variou de 0,8 a 1,5cm.

Verificou-se também, na cavidade abdominal, a próstata aumentada de tamanho, com contorno regular e microcistos, indicando hiperplasia prostática benigna.

A descrição dos achados ultra-sonográficos intestinais e outras alterações detectáveis no abdome, o diagnóstico ultra-sonográfico, os método diagnósticos e os diagnósticos dos cães com neoplasia intestinal são demonstrados no Quadro 3. 
Nos 4 cães com suspeita de tumores intestinais cujo diagnóstico final não estava associado a neoplasia intestinal, os sinais clínicos foram: vômitos esporádicos com piora progressiva (2), vômitos e diarréia intermitentes (1), diarréia com melena (1). Os diagnósticos foram: granuloma por fio de sutura não absorvível (2), enterite linfocítica-plasmocítica (1) e enterite eosinofílica (1).

Os métodos de diagnóstico definitivos empregados foram cirúrgicohistopatológico 2 (50\%), necroscópico-histopatológico 1 (25\%) e endoscópicohistopatológico $1(25 \%)$

Nos dois casos de granuloma a ultra-sonografia revelou espessamento focal da alça intestinal, leve perda da estratificação das camadas, e possível compressão extra-luminal. Em um dos casos, verificou-se que a massa estava aderida à parede intestinal de forma extramural (característica ecogênica e irregular). Os dois casos apresentavam sinais de processo obstrutivo intestinal, como: severa dilatação fluida intestinal segmentar anterior e peristaltismo não evolutivo. O espessamento parietal variou de 1,3 a $1,5 \mathrm{~cm}$. Em ambos, as lesões estavam localizadas no duodeno descendente, caudomedial ao rim direito.

No caso de enterite eosinofílica, foram visibilizados sonograficamente espessamentos parietais multifocais, ecogenicidade mista e com severa perda de estratificação das camadas intestinais. Alguns segmentos apresentavam-se dilatados por fluido, mas com peristaltismo evolutivo. $O$ espessamento parietal foi de $1,1 \mathrm{~cm}$. No caso de enterite linfocítica-plasmocítica, a alça intestinal encontrava-se discretamente espessada $(0,5 \mathrm{~cm})$, de forma difusa, a estratificação das camadas parietais estava preservada e não havia aumento de linfonodos mesentéricos.

Descrição dos achados ultra-sonográficos das alças intestinais e outras alterações detectáveis no abdome, diagnóstico ultra-sonográfico, método 
diagnóstico e seus respectivos diagnósticos nos cães com suspeita de neoplasia intestinal, estão representadas no quadro 4.

Ao analisar a ultra-sonografia convencional na suspeita de tumores em alças intestinais, de acordo com os critérios pré-estabalecidos nesta investigação para a diferenciação de tumores e processo inflamatório, foram suspeitos de processo neoplásico $8 \quad(100 \%)$ casos confirmados citologicamente ou anatomopatologicamente como neoplasia intestinal. Contudo, parâmetros suspeitos para processos neoplásicos também foram observados em 3 casos de enterite inflamatória - granulomatosa -, dois dos quais de reação por fio de sutura não absorvível após ovariossalpingo-histerectomia e um de enterite eosinofílica. A tabela 6 resume esses achados.

Tabela 6 - Resumo das características ultra-sonográficas dos processos neoplásicos ou inflamatórios intestinais quanto à espessura parietal, perda de estratificação das camadas e classificação de lesão (difusa ou focal), nos 12 cães com suspeita de neoplasia intestinal, atendidos no Serviço de diagnóstico por imagem (ultra-sonografia) do HOVET-FMVZ-USP - São Paulo - out. 2002 - out. 2003

\begin{tabular}{|c|c|c|c|c|}
\hline \multirow[b]{2}{*}{ Diagnóstico } & \multicolumn{4}{|c|}{ Alterações ultra-sonográficas } \\
\hline & $\begin{array}{l}\text { Espessura da } \\
\text { parede }>1,0 \mathrm{~cm}\end{array}$ & $\begin{array}{c}\text { Perda de } \\
\text { estratificação }\end{array}$ & $\begin{array}{l}\text { Lesão focal } \\
\text { (multifocal) }\end{array}$ & Lesão difusa \\
\hline Neoplasias (8) & 8 & 8 & 7 & 1 \\
\hline $\begin{array}{l}\text { Enterite } \\
\text { eosinofílica (1) }\end{array}$ & 1 & 1 & 1 & - \\
\hline $\begin{array}{l}\text { Granuloma a fio } \\
\text { (2) }\end{array}$ & 2 & $2( \pm)$ & 2 & - \\
\hline $\begin{array}{l}\text { Enterite linfocítica- } \\
\text { plasmocítica (1) }\end{array}$ & - & - & - & (1) \\
\hline
\end{tabular}

Nota: $( \pm)$ Alteração parcial na arquitetura das camadas intestinais 


\subsection{ORIGEM PANCREÁTICA}

As suspeitas de processo neoplásico pancreático foram confirmadas em 5 casos dos 114 que se apresentavam dentro dos critérios de inclusão, dos quais 4 apresentavam neoplasias pancreáticas e 1 foi excluído, - pancreatite crônica -. Dos 4 casos de tumores pancreáticos diagnosticados, todos eram neoplasias malignas.

As neoplasias pancreáticas acometeram 2 (50\%) machos e 2 (50\%) fêmeas, $2(50 \%)$ cães SRD e $2(50 \%)$ cães CRD, com faixa etária entre 7 e 15 anos e mediana igual a 11,5 anos.

Os sinais clínicos mais freqüentes foram: anorexia (4), perda de peso (3), massa abdominal à palpação (2), icterícia (1), distensão abdominal fluida (1), dispnéia (1), fraqueza (1) e desmaio (1).

Os tipos diagnósticos cito-histológicos foram: neoplasia do pâncreas exócrino - adenocarcinoma pancreático (3), neoplasia do pâncreas endócrino - insulinoma (1).

Os métodos de diagnóstico definitivo empregados foram: necroscópicohistopatológico 2 (50\%), cirúrgico-histopatológico 1 (25\%) e citológico 1 (25\%).

As características ultra-sonográficas detectadas nos casos de adenocarcinoma pancreático foram: presença de massas com limites imprecisos em lobo pancreático direito (2), massas de ecogenicidade heterogênea, com áreas hipoecóicas e hiperecóicas (2), presença de aumento de ambos os lobos pancreáticos associada a massa hipoecóica de contorno irregular em porção caudal de lobo pancreático direito (1). Em todos estes casos a massa alterava a forma e a margem do órgão. O tamanho aproximado variou de 1,2 x 1,1 cm a 5,4 x 6,3cm de diâmetro.

Em um dos casos de adenocarcinoma pancreático foi verificada a presença de duas massas. Foi possível identificar a origem de apenas uma dessas massas; a 
não identificação da outra massa deveu-se ao seu severo deslocamento caudal; as características ultra-sonográficas dessa massa eram: contorno irregular, parede ecogênica e espessa associada a áreas cavitárias - preenchidas por conteúdo anecóico com grande quantidade de pontos ecogênicos em suspensão.

Como achados ultra-sonográficos denominados indiretos foram verificados, nos casos de adenocarcinoma pancreático: dilatação de ducto cístico, vias biliares intra-hepáticas e colédoco associado a lítiase biliar (1); espessamento duodenal com perda de estratificação das camadas (1), espessamento duodenal com estratificação das camadas parietais preservadas porém, com plissamento (1); efusão abdominal e mesentério hiperecóico (3).

No cão com suspeita de tumor pancreático cujo diagnóstico final não estava associada à neoplasia, os sinais clínicos foram: vômitos esporádicos, hiporexia, febre e presença de massa detectada ao exame radiográfico. O diagnóstico definitivo empregado foi necroscópico-histológico, e tratava-se de pancreatite crônica e abscesso pancreático. As características ultra-sonográficas observadas nesse caso foram: presença de massa, contornos irregulares, ecogenicidade severamente heterogênea, predominantemente hipoecogênica, em porção cranial de lobo direito de pâncreas; a massa media aproximadamente 4,3 × 5,8cm; outras alterações observadas foram espessamento de bexiga crânio-ventral e pielectasia bilateral.

O quadro 5 traz as características ultra-sonográficas do pâncreas, outras alterações em cavidade abdominal, o diagnóstico ultra-sonográfico, os métodos diagnósticos e as conclusões diagnósticas referente a tais casos.

Com relação a suspeita de tumores pancreáticos exócrinos baseados na ultra-sonografia convencional, e de acordo com os critérios pré-estabelecidos neste trabalho na diferenciação de massas benignas ou malignas, 3 casos $(100 \%)$ 
suspeitos de lesões malignas (associadas a processos neoplásicos) foram confirmados como sendo adenocarcinoma pancreático. Contudo, parâmetros suspeitos para malignidade e sugestivos de neoplasia pancreática também foram observados em um caso de pancreatite crônica. A tabela 7 demonstra esses achados.

Tabela 7 - Distribuição conjunta do padrão ecotextural (USG) das lesões pancreáticas pela natureza das mesmas, dos 4 cães com massas pancreáticas detectadas a ultra-sonografia bidimendional, atendidos no Serviço de diagnóstico por imagem (ultra-sonografia) do HOVET-FMVZUSP, segundo a origem da lesão - São Paulo - out. 2002 - out. 2003

\begin{tabular}{ccc}
\hline \hline USG & Benignas & Malignas \\
\hline \hline Tipo I & - & - \\
Tipo II & & $1(1+)$ \\
Tipo III & $1(1+)$ & $2(2+)$ \\
\hline \hline Total & 1 & 3 \\
\hline \hline
\end{tabular}

Tipo I: Lesões focais ou multifocais de contorno regular (hipoecóicas ou hiperecóicas) em somente um órgão abdominal.

Tipo II: Alterações focais ou multifocais de contornos irregulares, hipoecóicas, hiperecóicas ou em "alvo" (média complexidade).

Tipo III: Alterações focais ou multifocais de ecogenicidade mista (heterogênea), nódulo em "alvo", nódulos cavitários, com microcalcificações ou calcificações, que alteram o contorno e/ou a cápsula do órgão (alta complexidade)

+ : $\quad$ representa alterações em outros órgãos, linfonodomegalia adjacente e/ou ascite.

Ao analisar a ultra-sonografia modo bidimensional na suspeita de tumores pancreáticos exócrinos foi possível identificar a localização da massa pancreática; entretanto, não foi possível estabelecer diferenciação segura entre processo neoplásico e pancreatite crônica. Alguns sinais indiretos, como espessamento de duodeno, litíase biliar e sinais de processo obstrutivo biliar forneceram maior suspeita de processo neoplásico, mas não foram muito elucidativos. 
Por meio do exame ultra-sonográfico foi possível identificar o nódulo hipoecóico de $0,5 \mathrm{~cm}$ de diâmetro localizado no lobo direito do pâncreas no caso de tumor pancreático endócrino - insulinoma.

\subsection{RESULTADOS DO DOPPLER COLORIDO}

A avaliação pela técnica Doppler colorido e/ou Power Doppler só foi realizada em 3 cães com tumores hepáticos, todos malignos. No caso de carcinoma hepático, observou-se a presença de vascularização central e periférica nos nódulos examinados - padrão III -. Nos 2 casos de colangiocarcinoma avaliados pela técnica, verificou-se a presença de vascularização somente central - padrão IV (1) , e central e periférica - padrão III (1). Neste último, a presença de fluxo sangüíneo também foi verificada na parede dos nódulos cavitários.

Os outros cães com tumores hepáticos não foram avaliados pelo Doppler colorido, em decorrência da dificuldade de controlar os movimentos respiratórios e os movimentos do animal, e da presença de meteorismo intestinal.

A avaliação pela técnica Doppler colorido e/ou Power Doppler só foi possível em 4 cães com lesões intestinais: um caso de adenocarcinoma, um caso de linfoma intestinal, um cão com adenoma de cólon e um caso de enterite eosinofílica; nos 3 casos foi verificada presença de vascularização central e periférica, padrão III, pelo critério estabelecido. Os outros cães com lesões intestinais não foram avaliados pelo Doppler colorido, basicamente devido à dificuldade de controlar os movimentos respiratórios, os movimentos do animal, e à presença de meteorismo intestinal. 
A avaliação pela técnica Doppler colorido e/ou Power Doppler só foi possível em um cão, no qual foi visualizada a presença de vascularização central (padrão III) no nódulo hipoecóico de $0,5 \mathrm{~cm}$ no caso do insulinoma.

Não foi possível o mapeamento colorido e/ou a avaliação do envolvimento vascular nos casos de lesões pancreáticas nos animais deste estudo. 
Quadros 


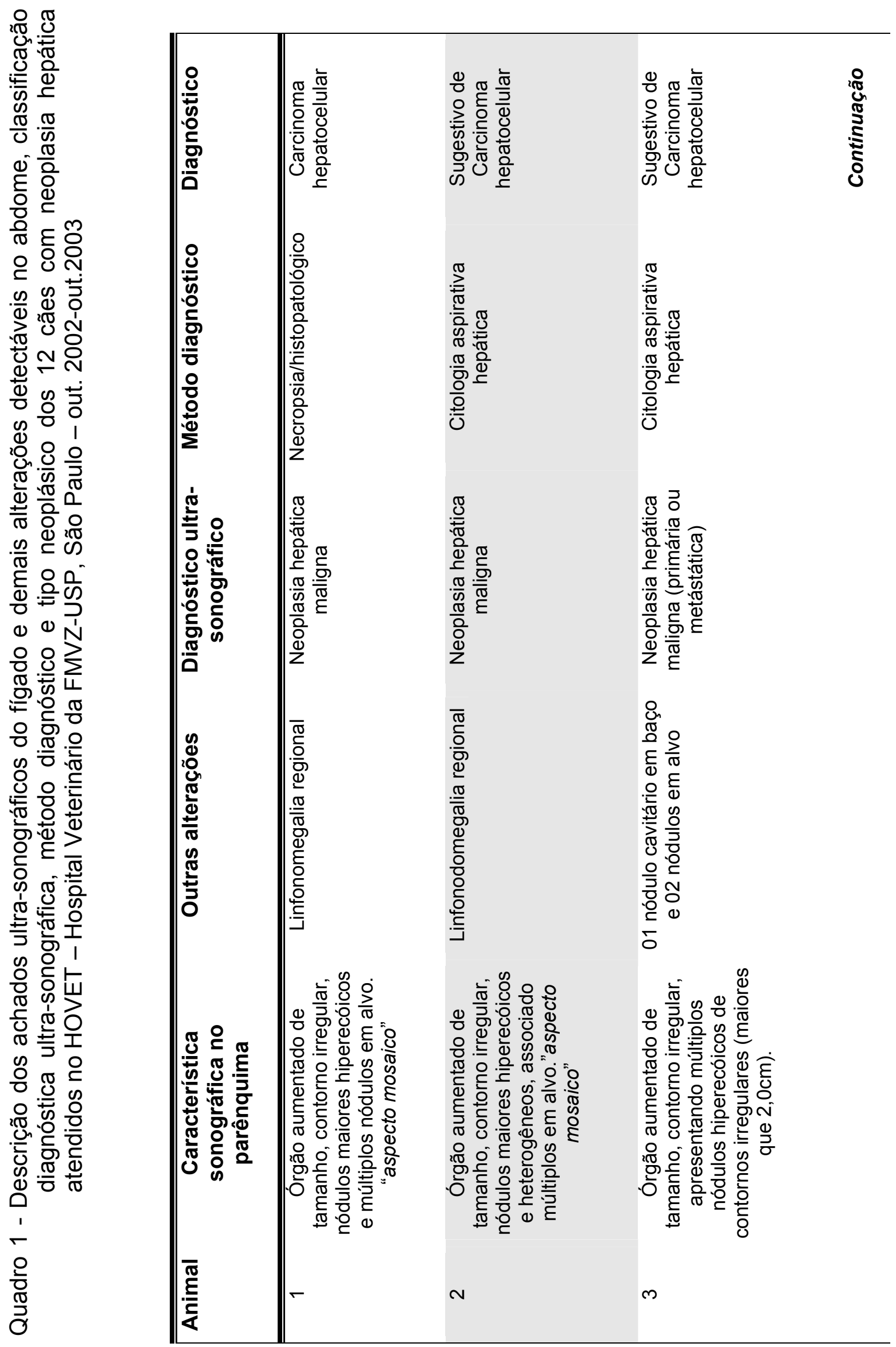




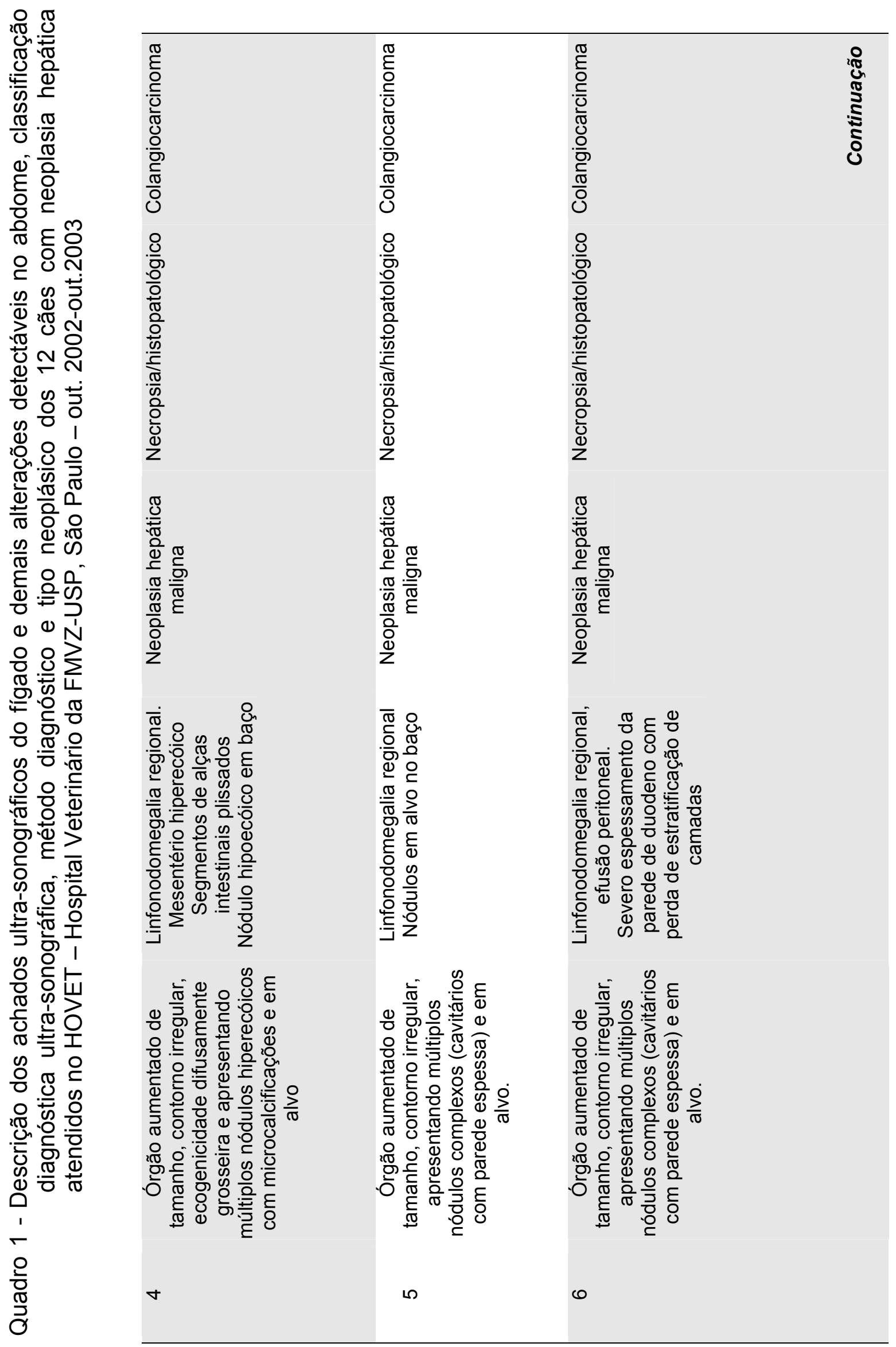




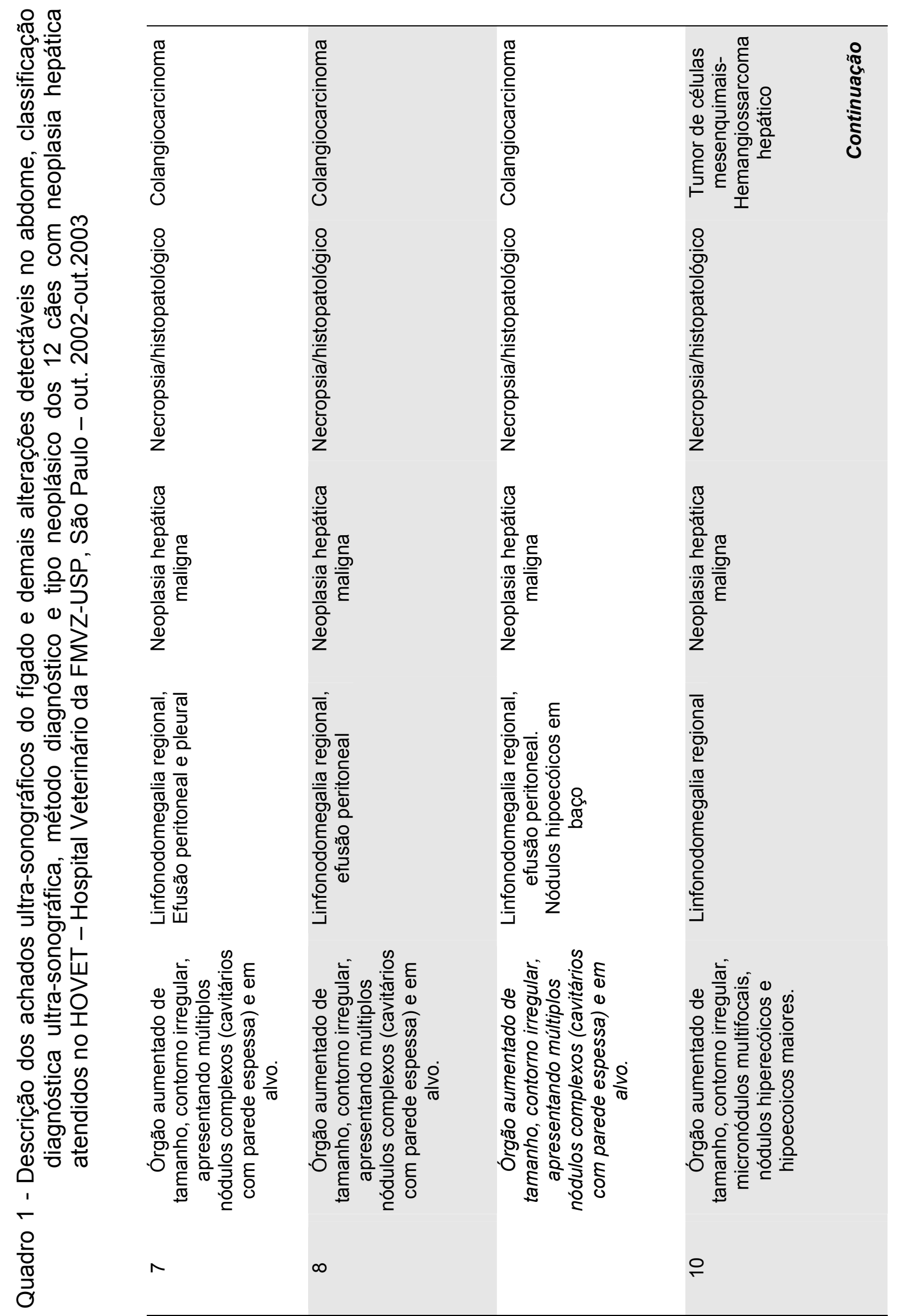




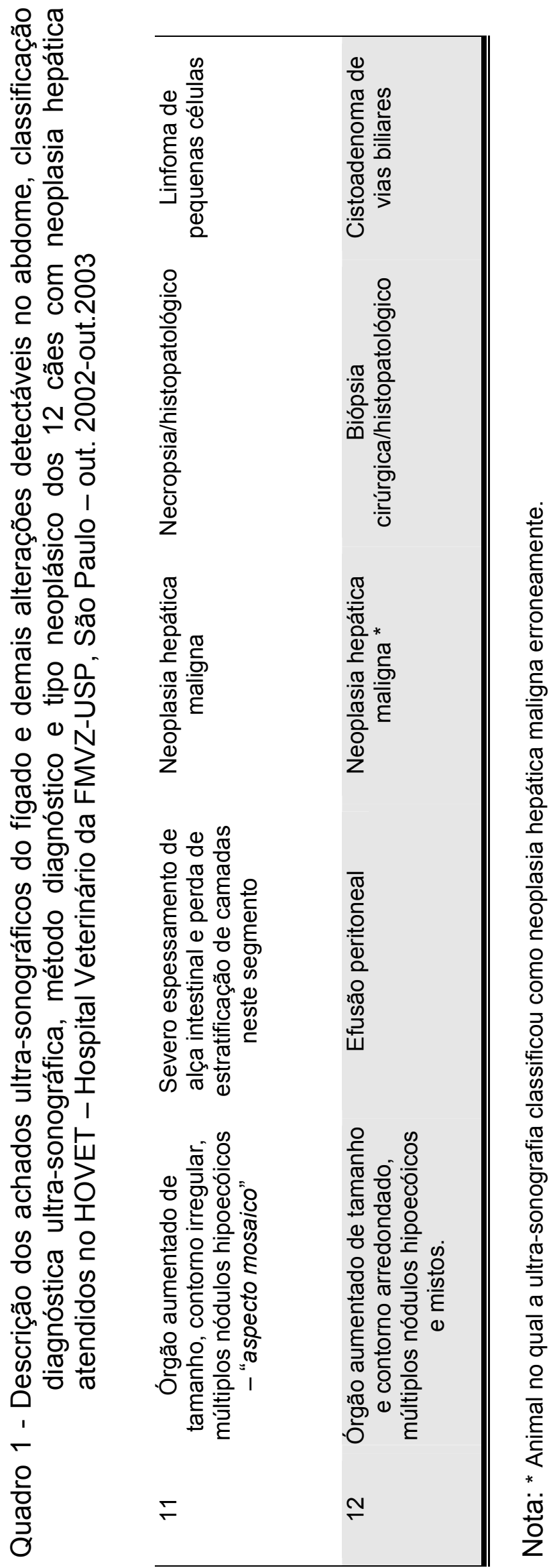




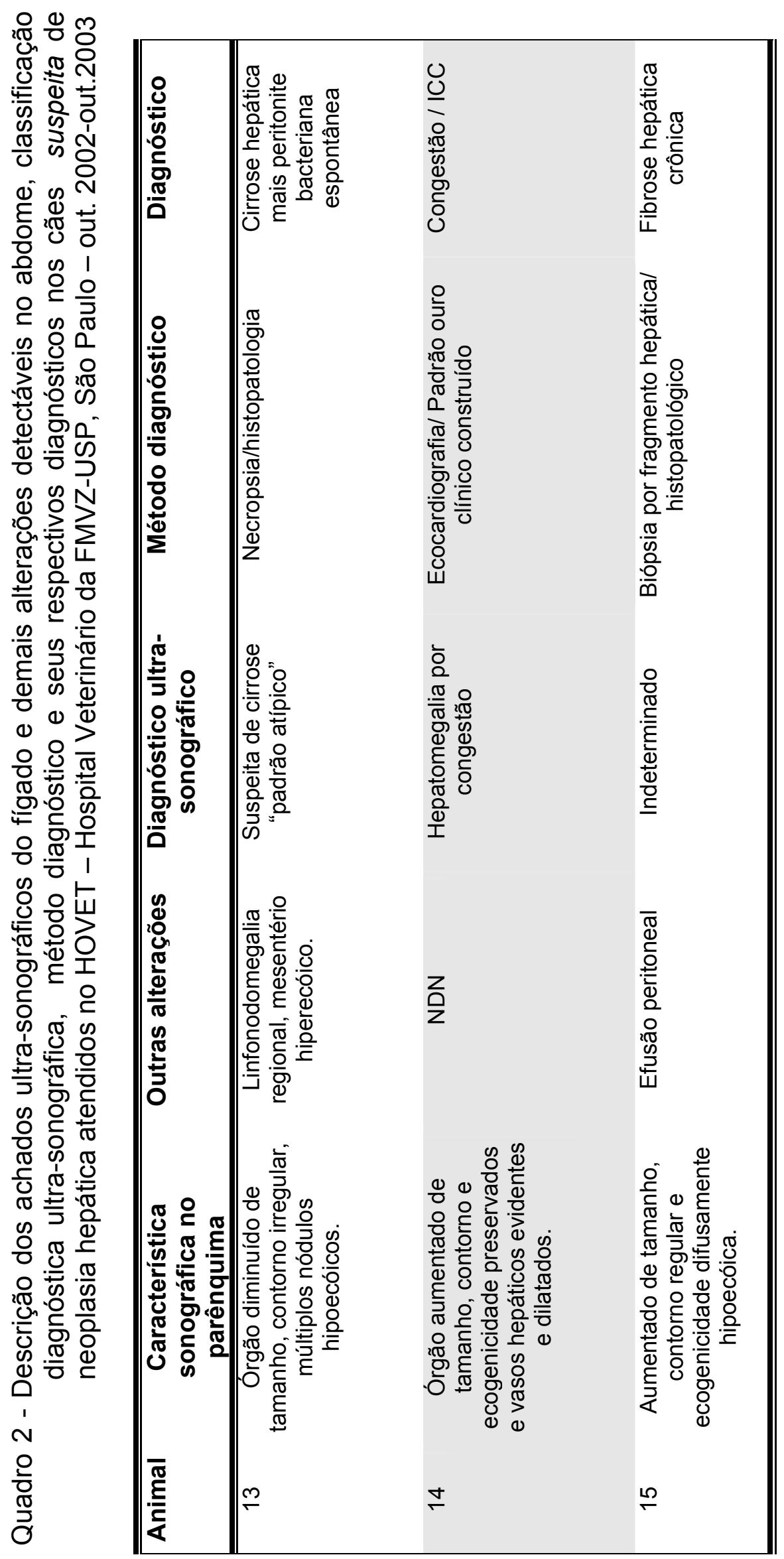




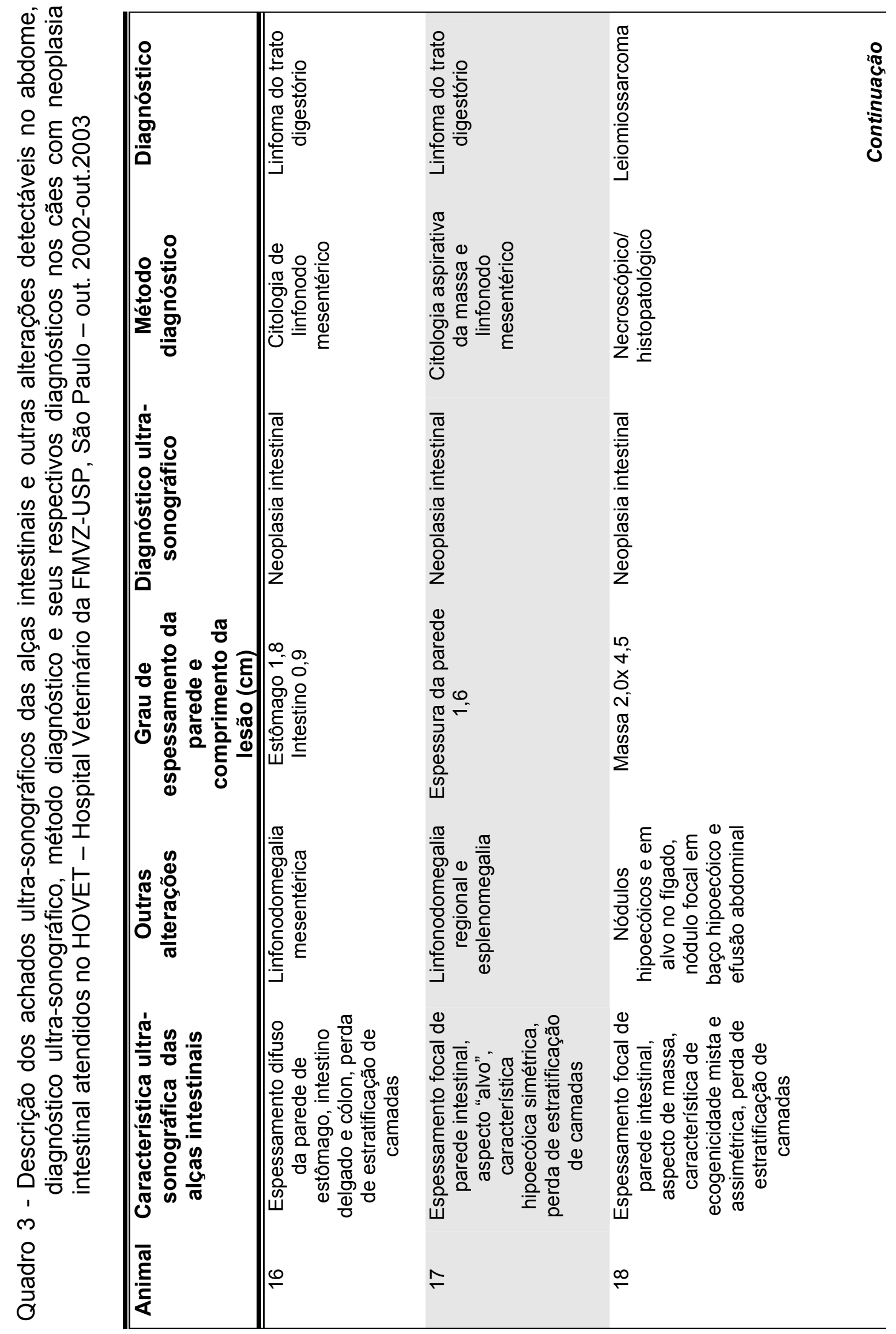




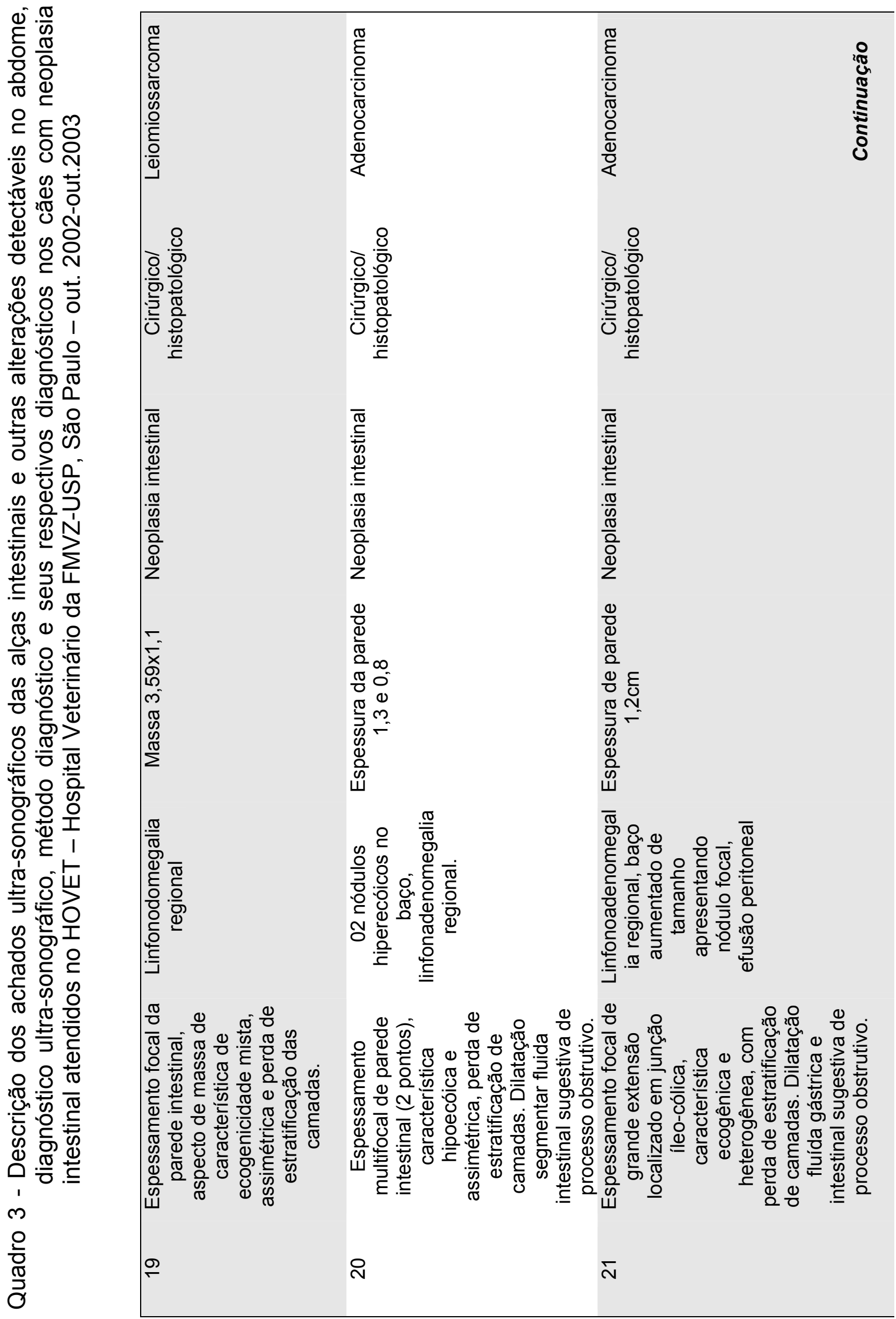




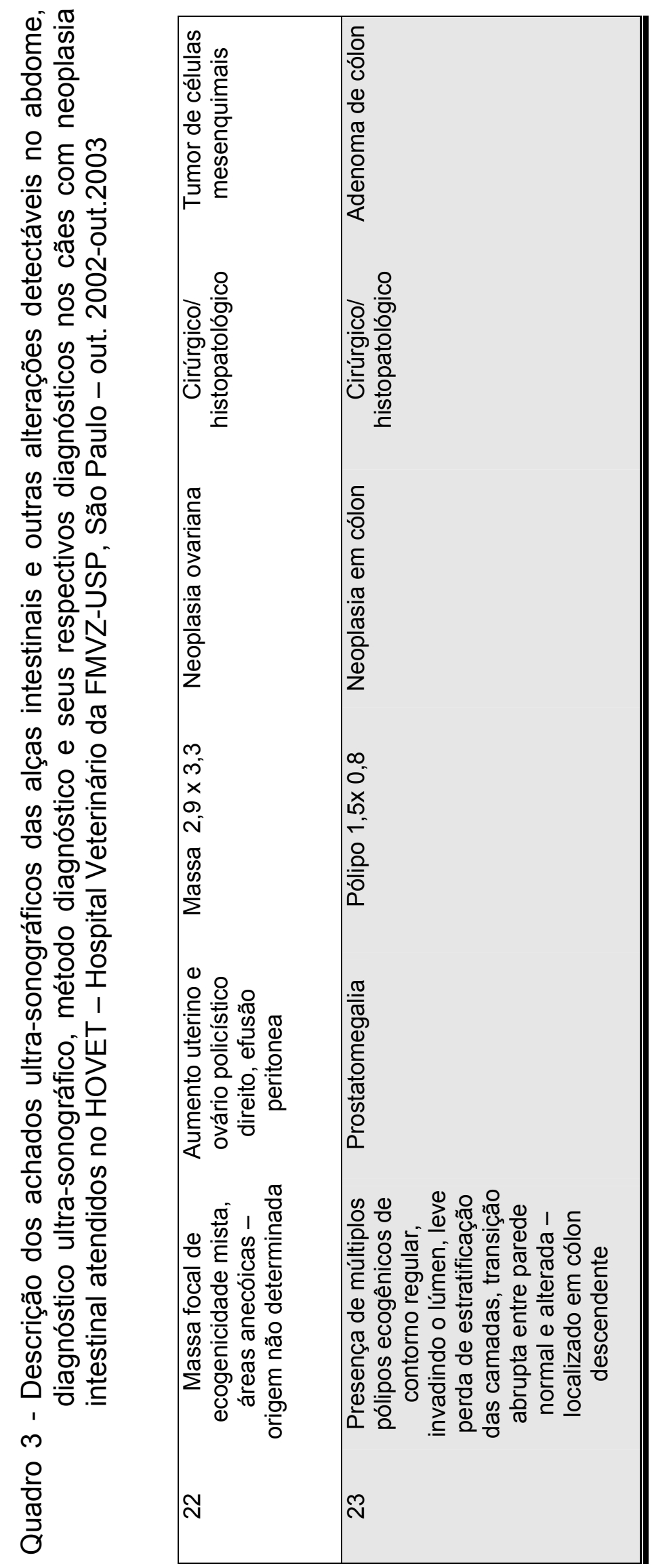




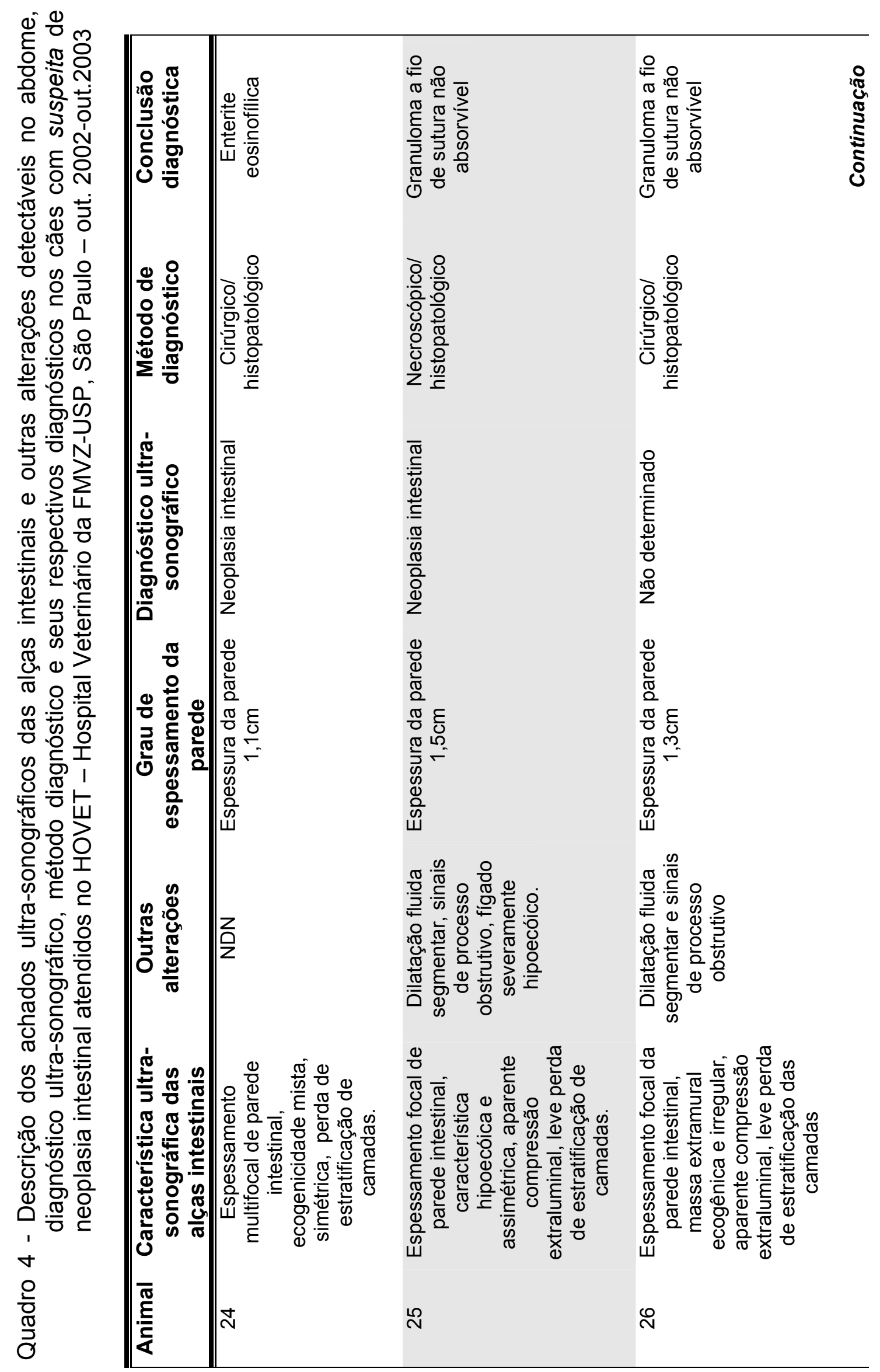




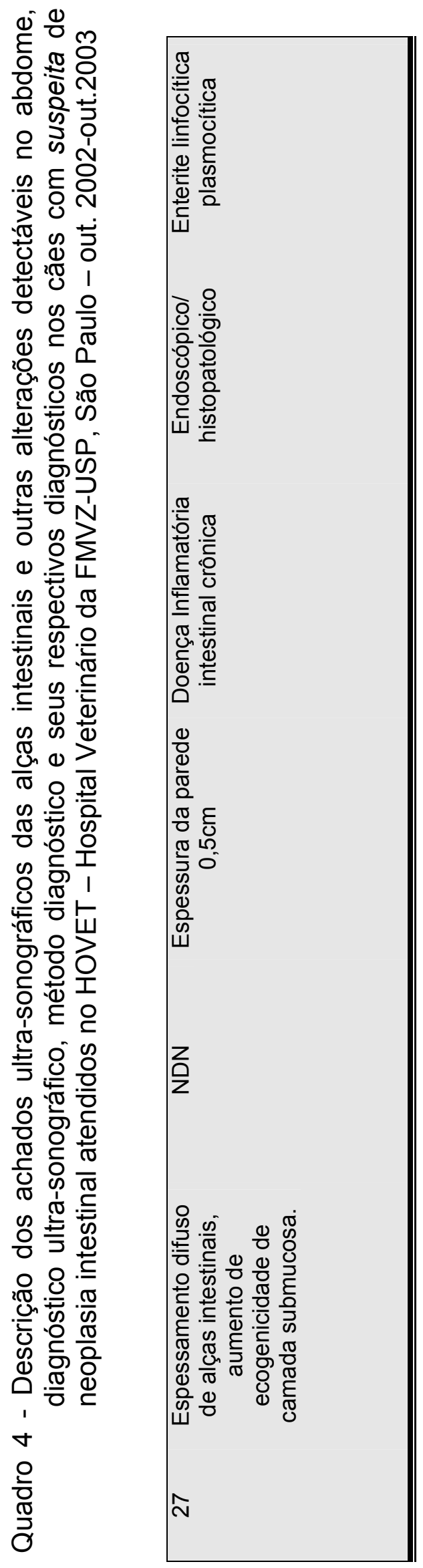


ฮ์ ฮั่

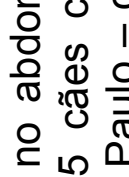

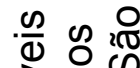

要 0

ర్

О

Ф 등

'0.

전

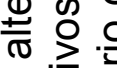

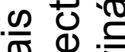

즌 ญำ

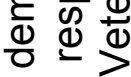

(1) $0 \frac{\pi}{\pi}$

얼 을 흥

¿. 오

힌단

즈음

으 응 웅

온

을

त

엉 음

$0 . \overline{0}$

.

ס ర

क⿺ 진

它站

ป ชู ล

유훙

ชั

등 흥 응

응 잉 Ð

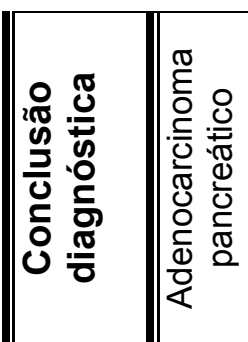

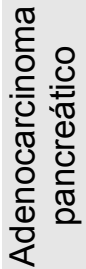



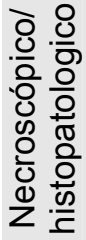

유월

는 ญ

क त $\frac{\pi}{0}$ क

'

10

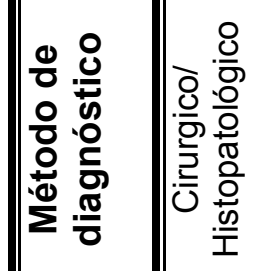

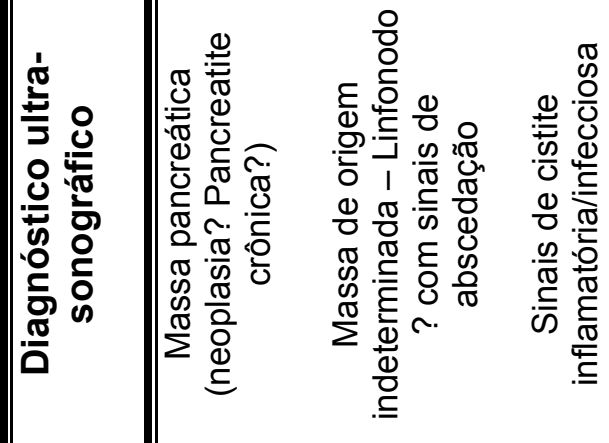

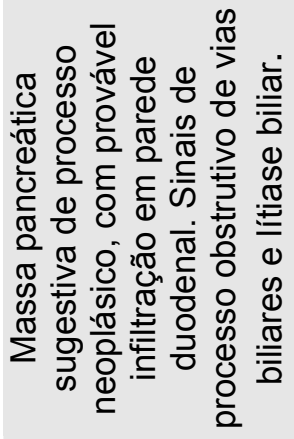

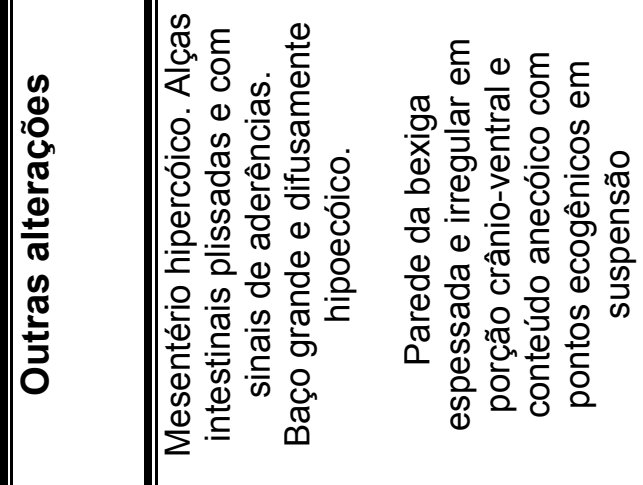

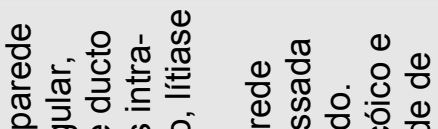

유용 \&

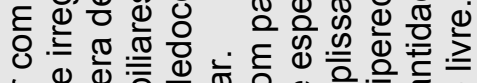

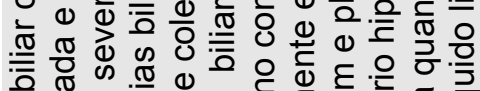

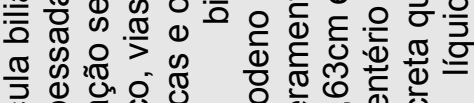

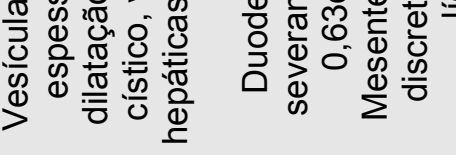

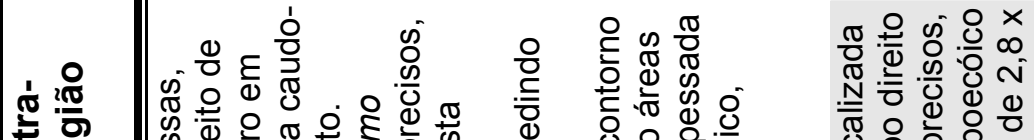

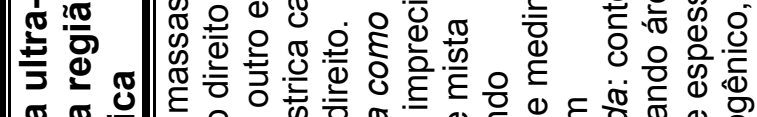

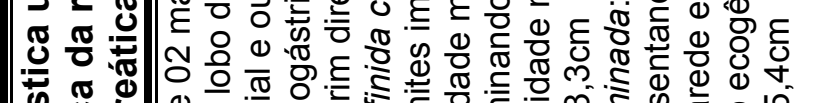

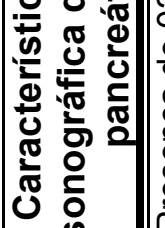

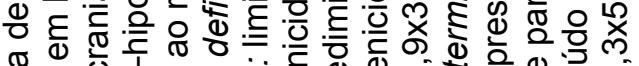

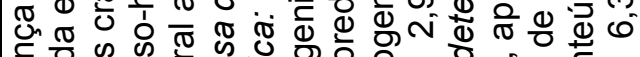

D.

¿

需

으 2

之.

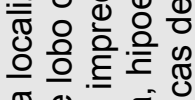

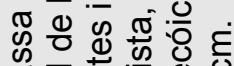

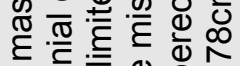

क 뉸

정

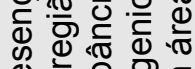

至

$\frac{\text { 음 }}{\frac{\text { to }}{2}}$

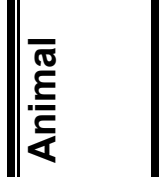

ㄱ 
Е 흥

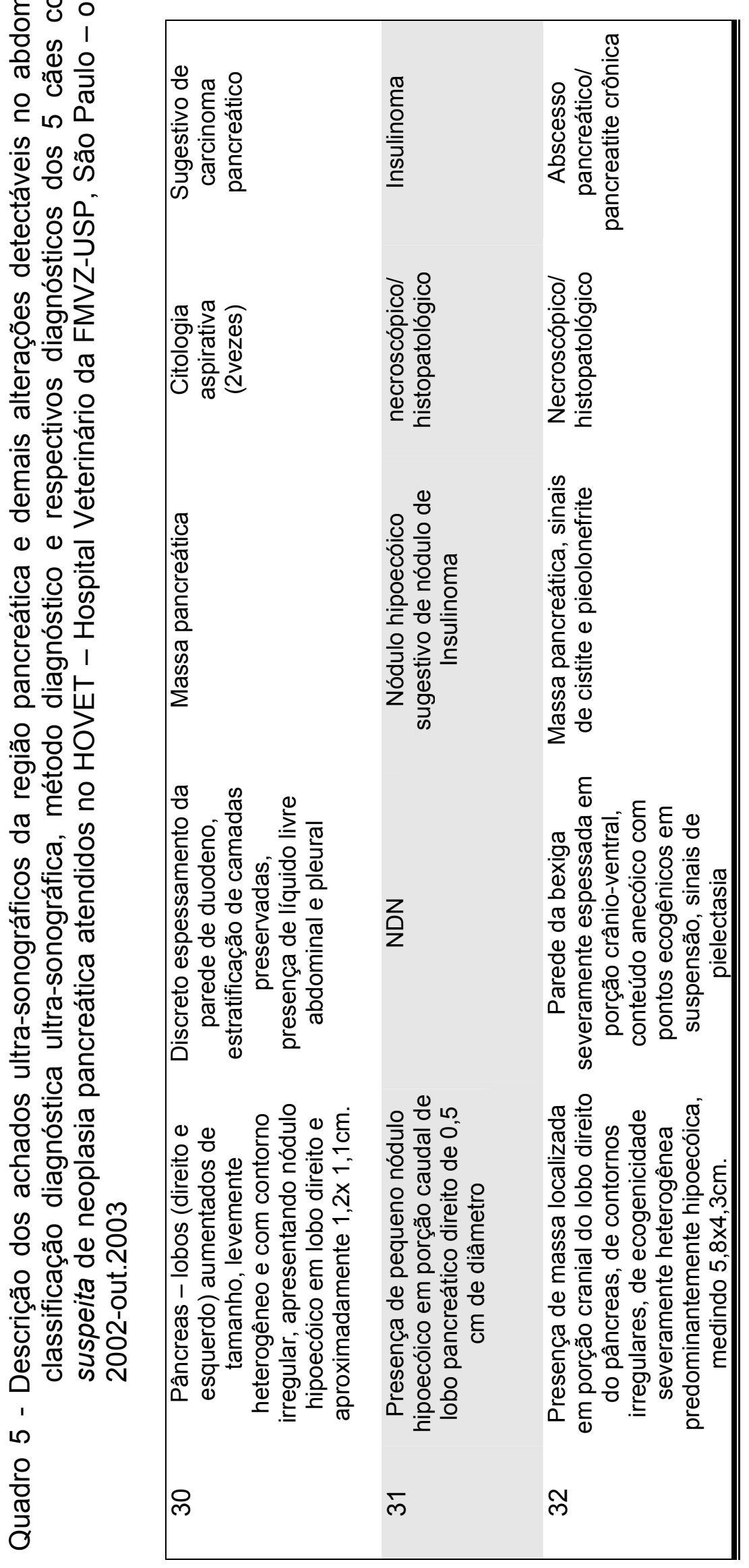


Figuras 


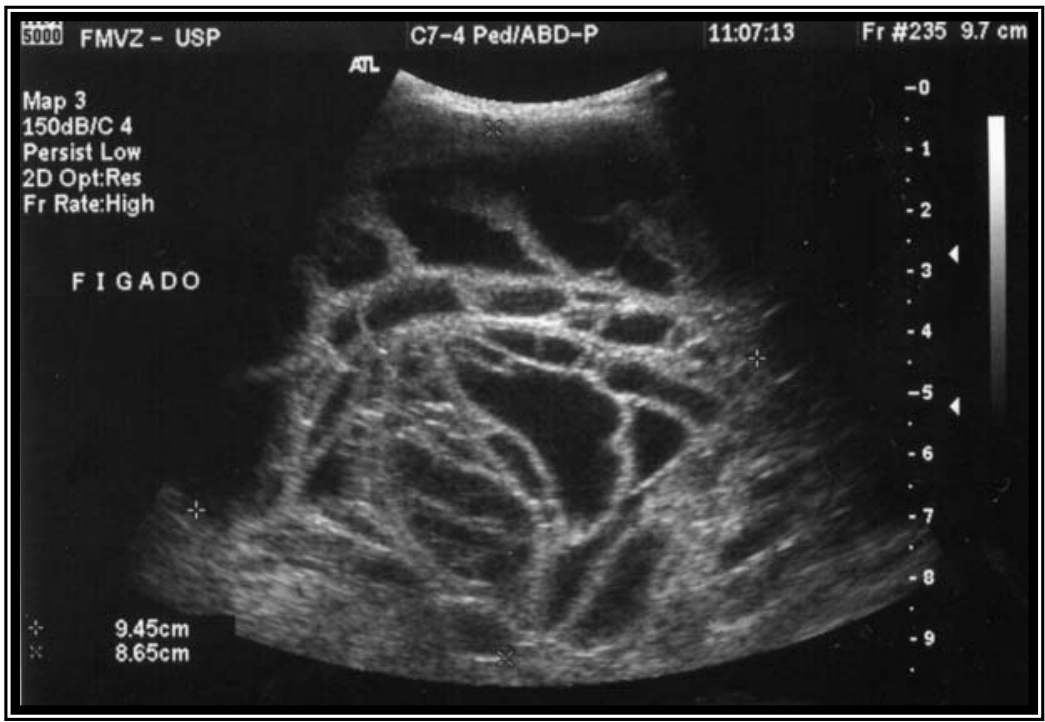

Figura 1: Imagem ultra-sonográfica de área cavitária complexa - septações internas - . Colangiocarcinoma hepático

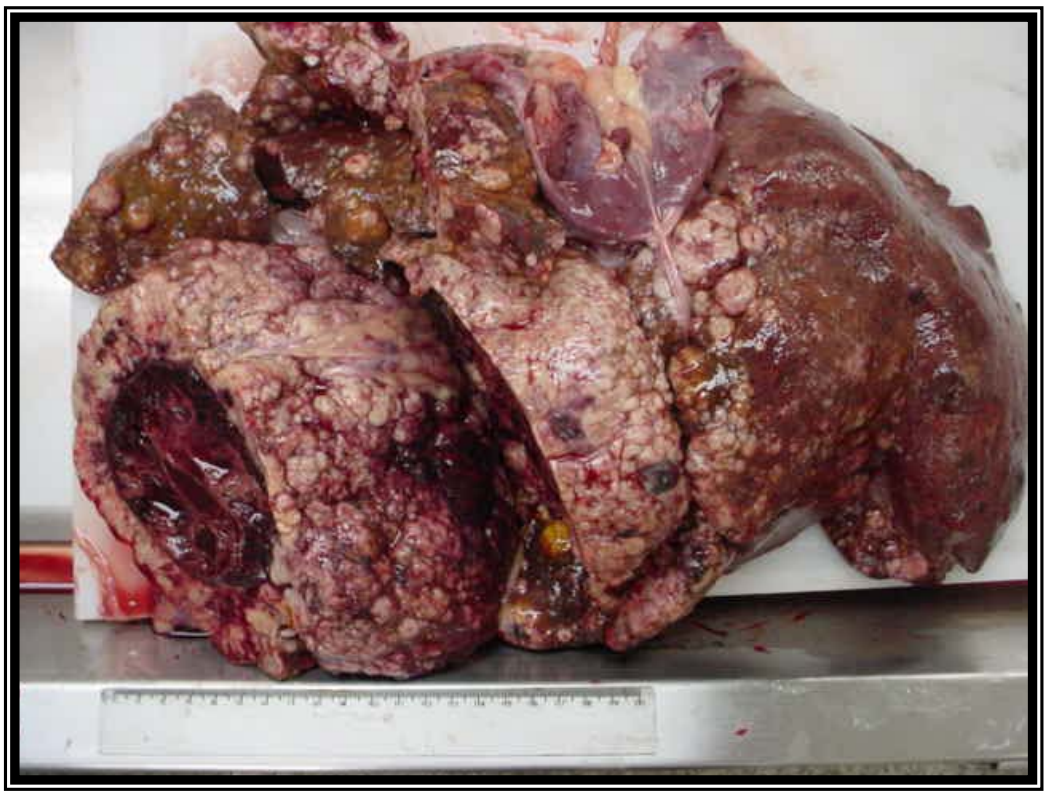

Figura 2: Aspecto macroscópico do Colangiocarcinoma hepático 


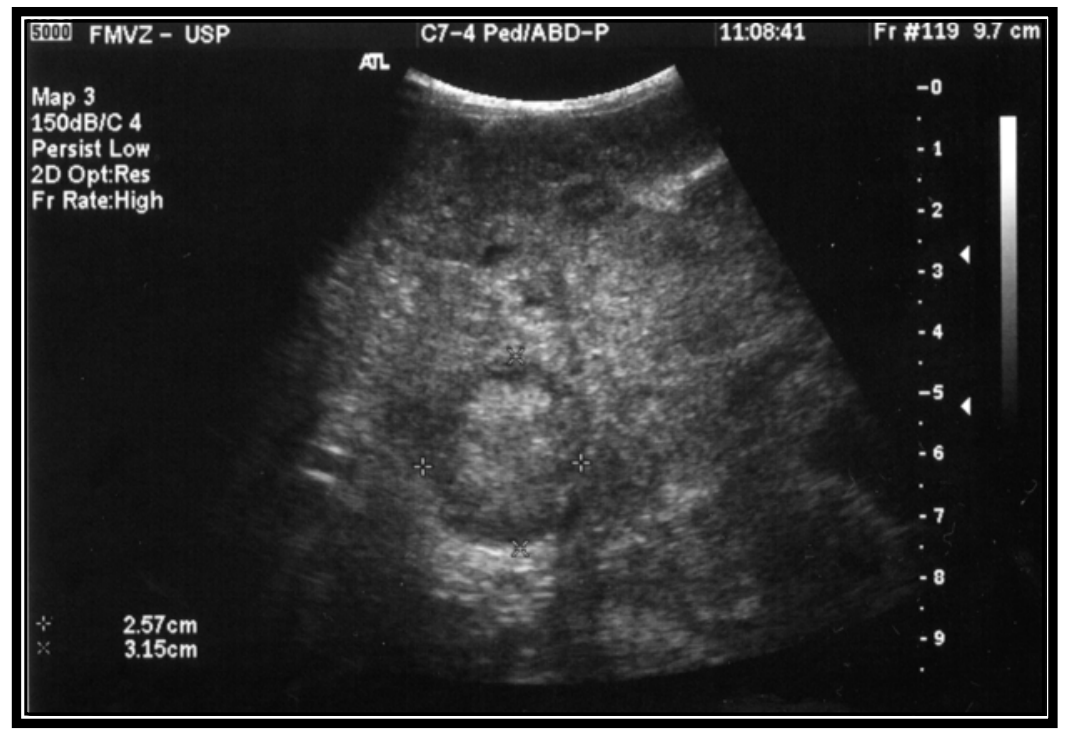

Figura 3: Imagem ultra-sonográfica de lesão em aspecto "alvo" no parênquima hepático. Colangiocarcinoma hepático

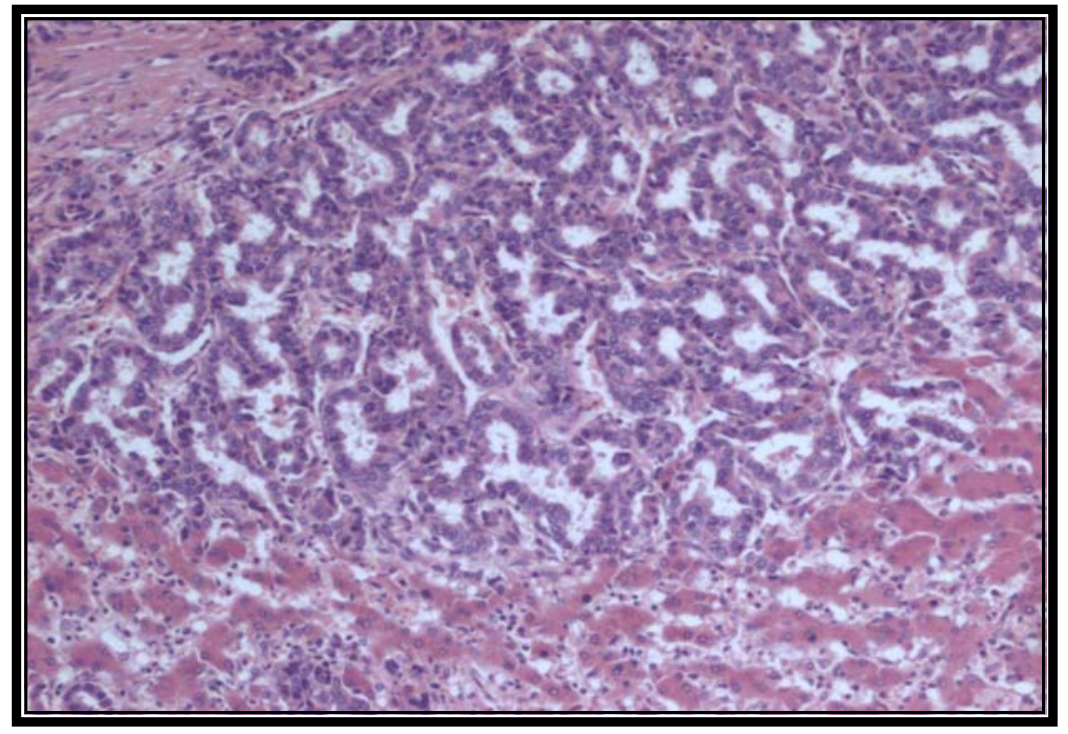

Figura 4: Foto micrografia - Colangiocarcinoma hepático H\&E (10x) 


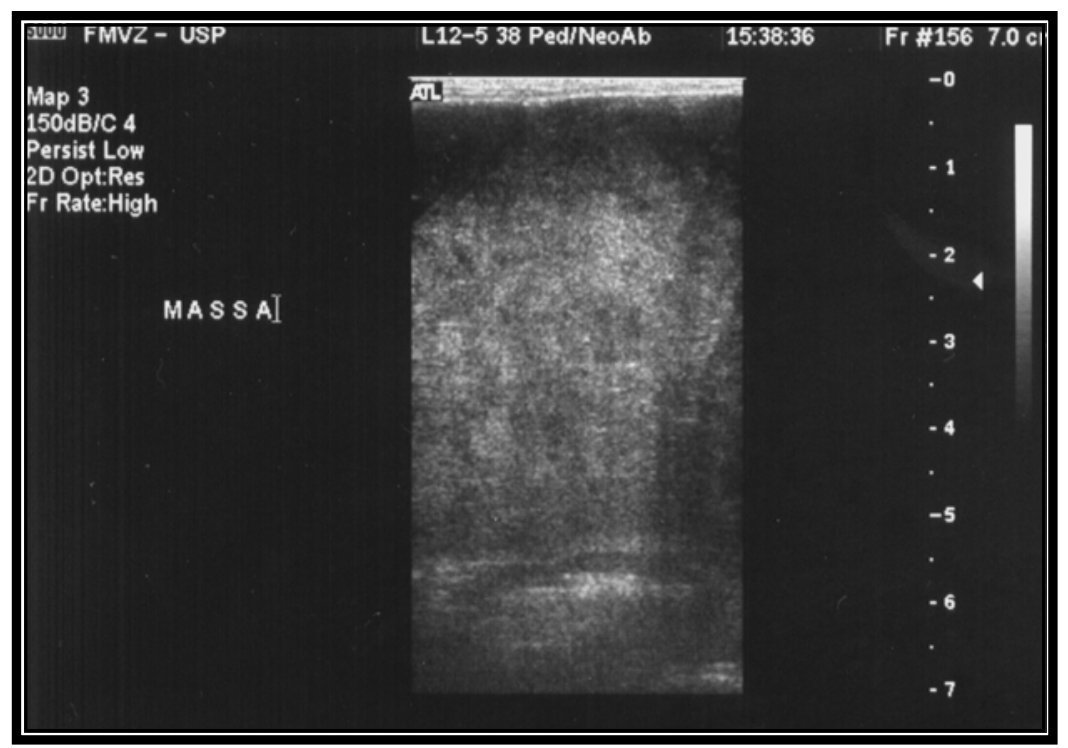

Figura 5: Imagem ultra-sonográfica de múltiplos nódulos hiperecóicos e em "alvo" - aspecto pavimentoso mosaico -. Carcinoma hepatocelular

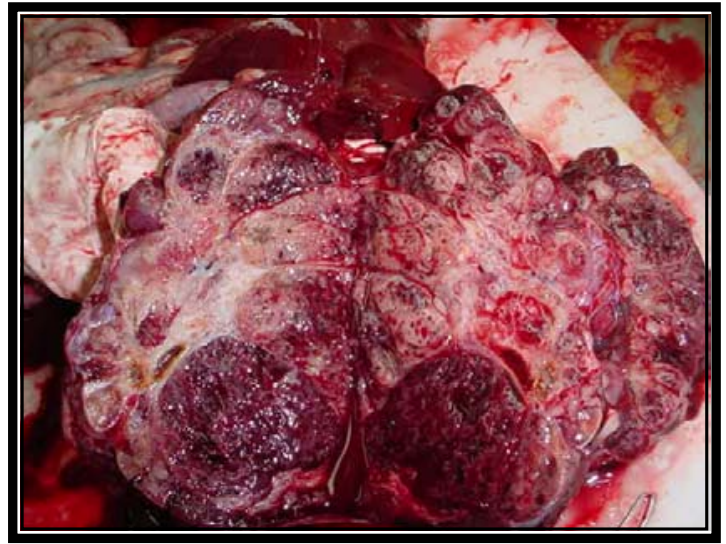

Figura 6: Aspecto macroscópico do Carcinoma hepatocelular

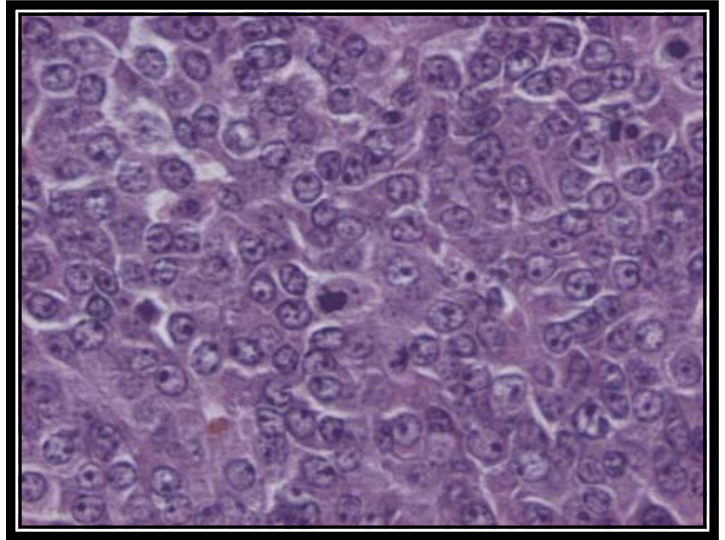

Figura 7: Foto micrografia - Carcinoma hepatocelular H\&E (40x) 


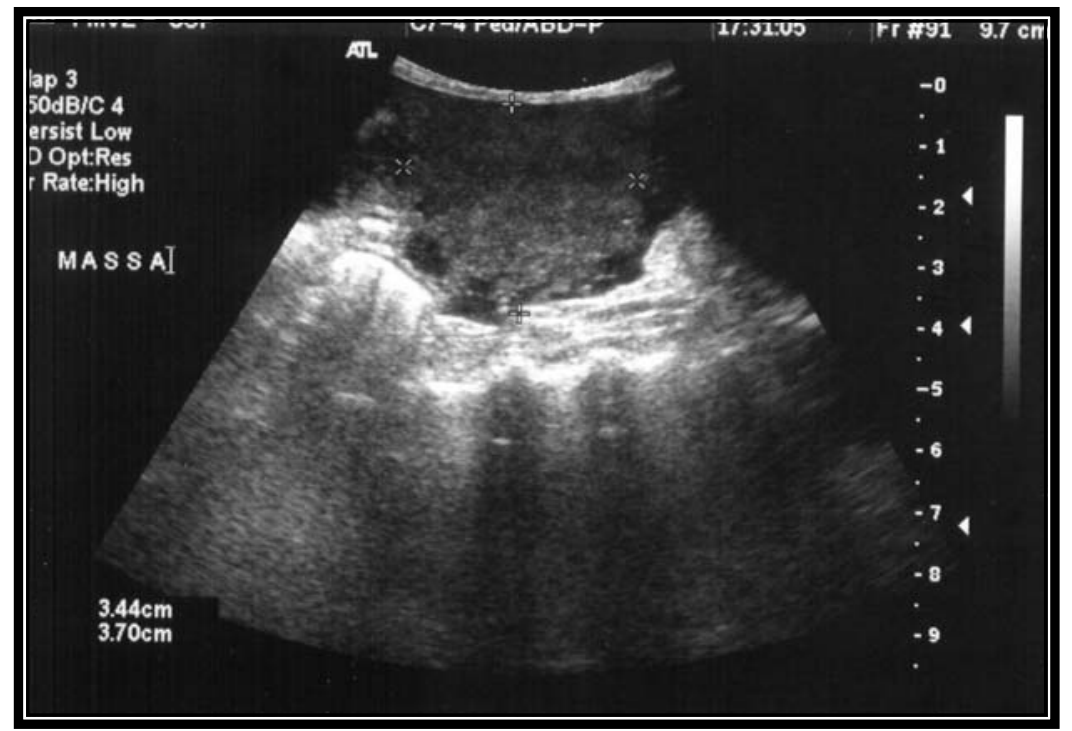

Figura 8: Imagem ultra-sonográfica de massa ecogênica mista com áreas anecóicas periféricas. Tumor de células mesenquimais intestinal

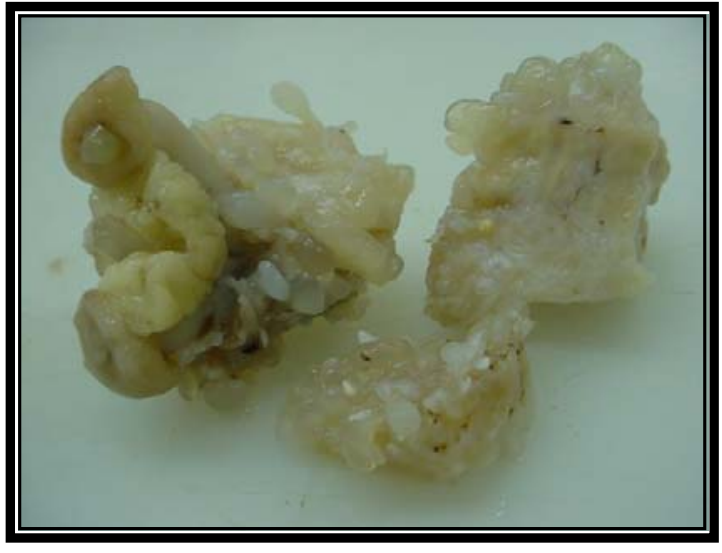

Figura 9: Aspecto macroscópico do Tumor de células mesenquimais intestinal

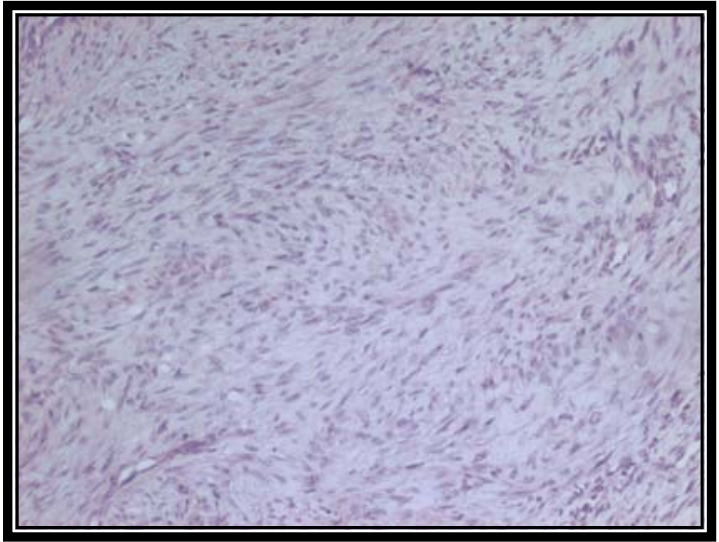

Figura 10: Foto micrografia - Tumor de células mesenquimais intestinal H\&E (10x) 


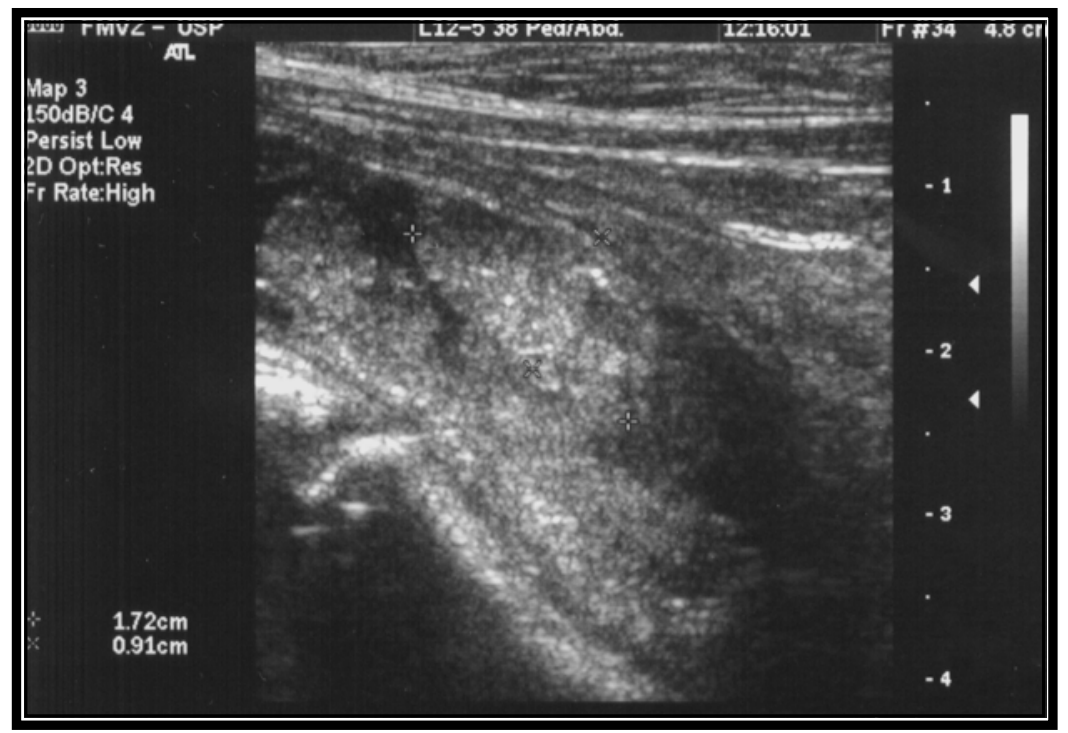

Figura 11: Imagem ultra-sonográfica de múltiplos nódulos ecogênicos de contorno regular, invadindo o lúmen associado a leve perda de estratificação das camadas parietais. Adenoma de cólon

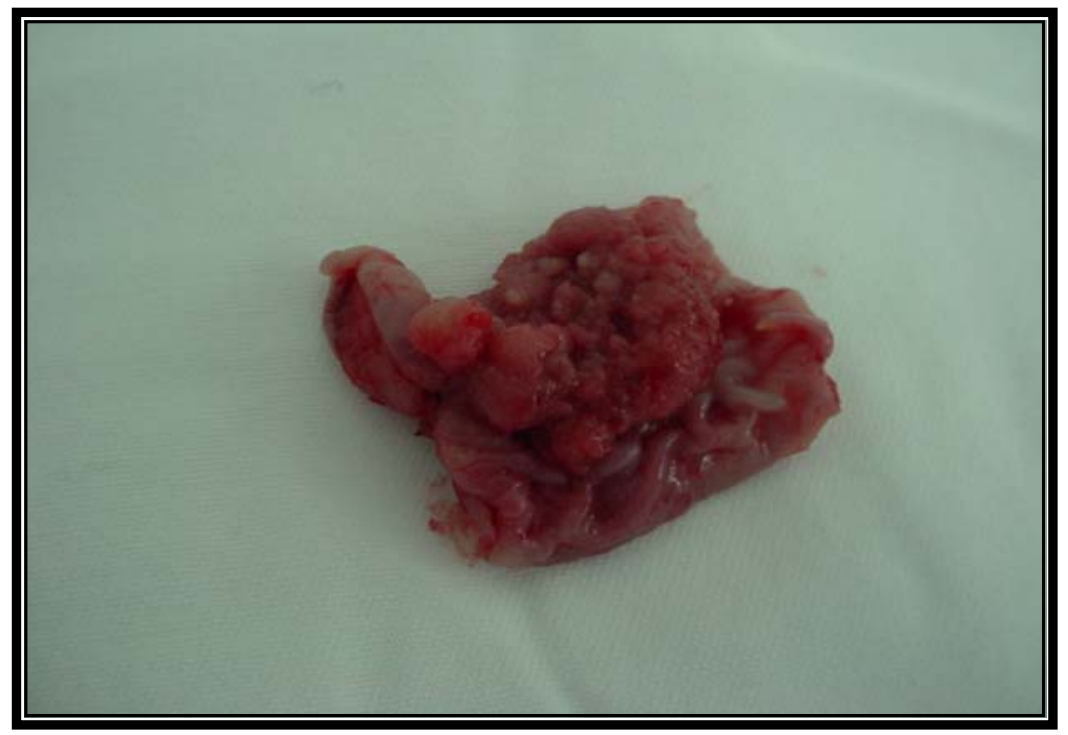

Figura 12: Aspecto macroscópico de Adenoma de cólon 


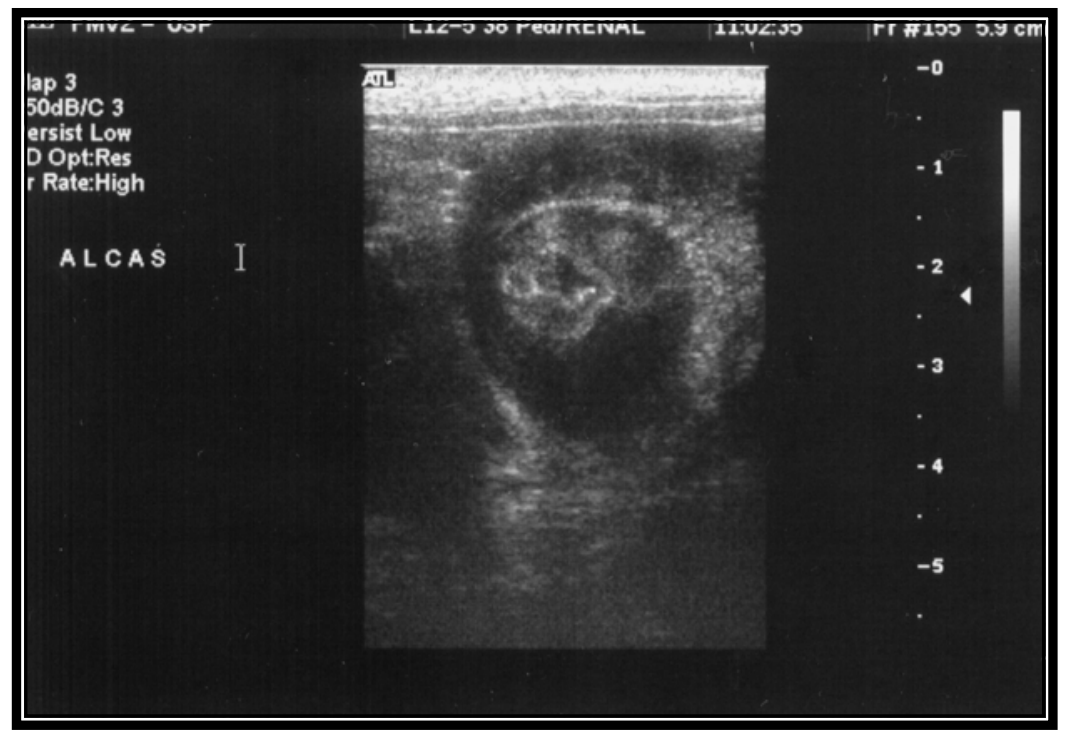

Figura 13: Imagem ultra-sonográfica do corte transversal de segmento intestinal com severo espessamento e perda de estratificação parietal. Adenocarcinoma Intestinal

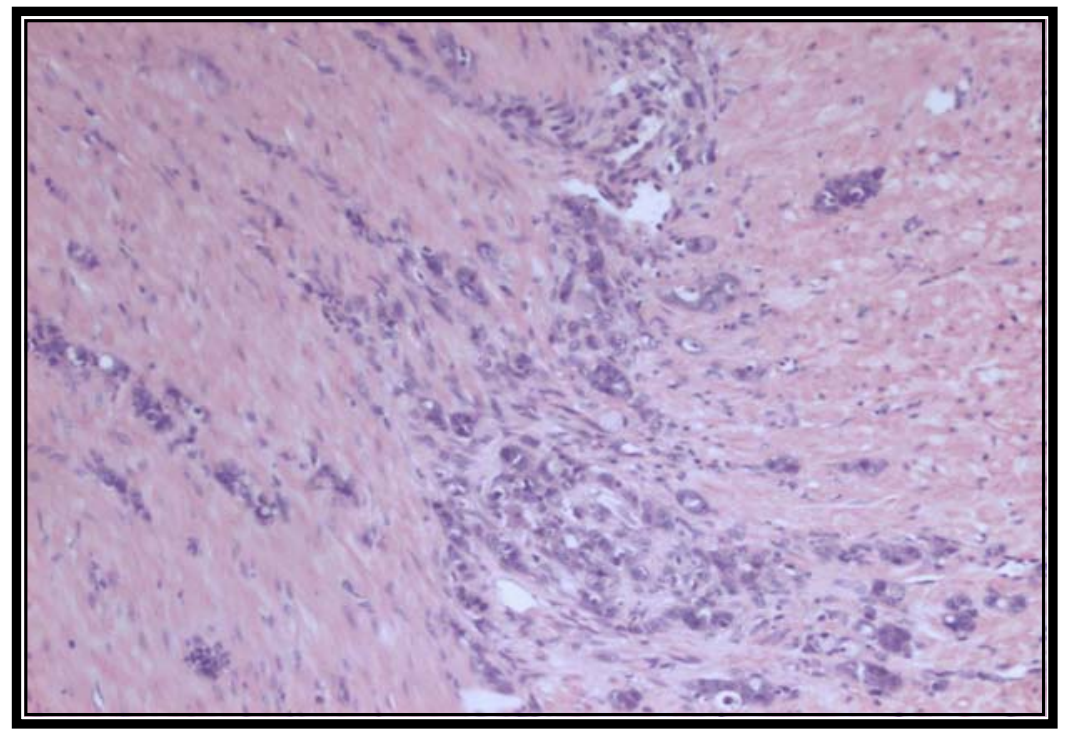

Figura 14: Foto micrografia - Adenocarcinoma Intestinal H\&E (20x) 


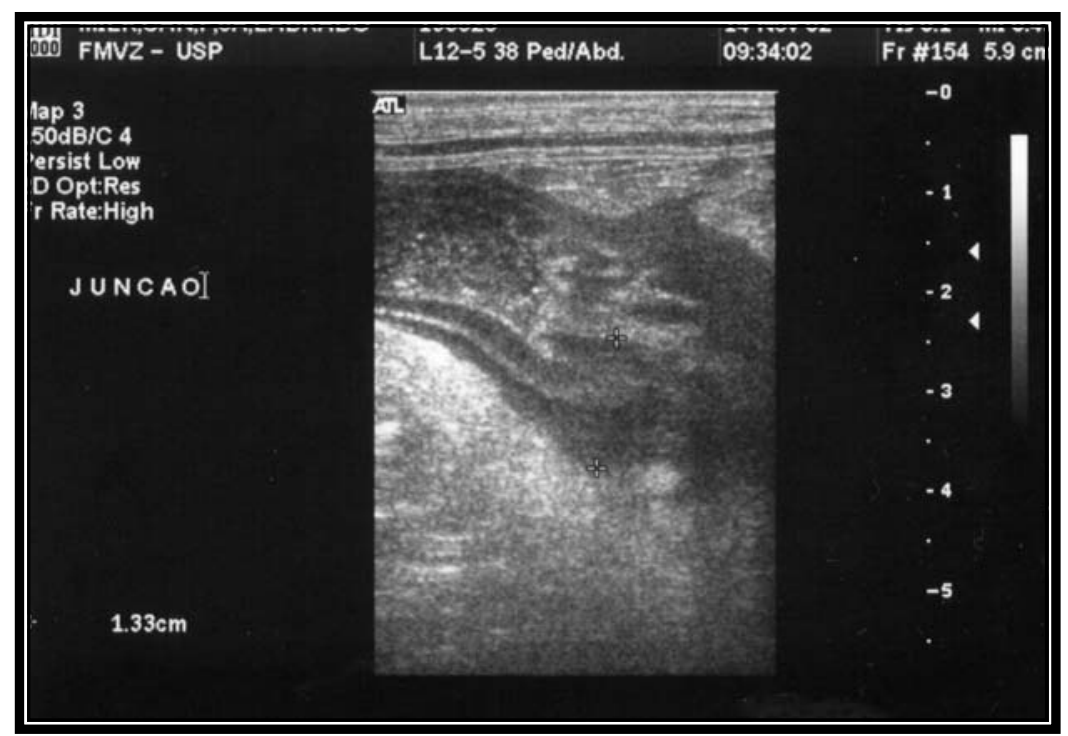

Figura 15: Imagem ultra-sonográfica de corte longitudinal de segmento de alça intestinal com severo espessamento parietal, perda de estratificação parietal e dilatação fluida intraluminal anterior. Granuloma intestinal a fio de sutura não absorvível

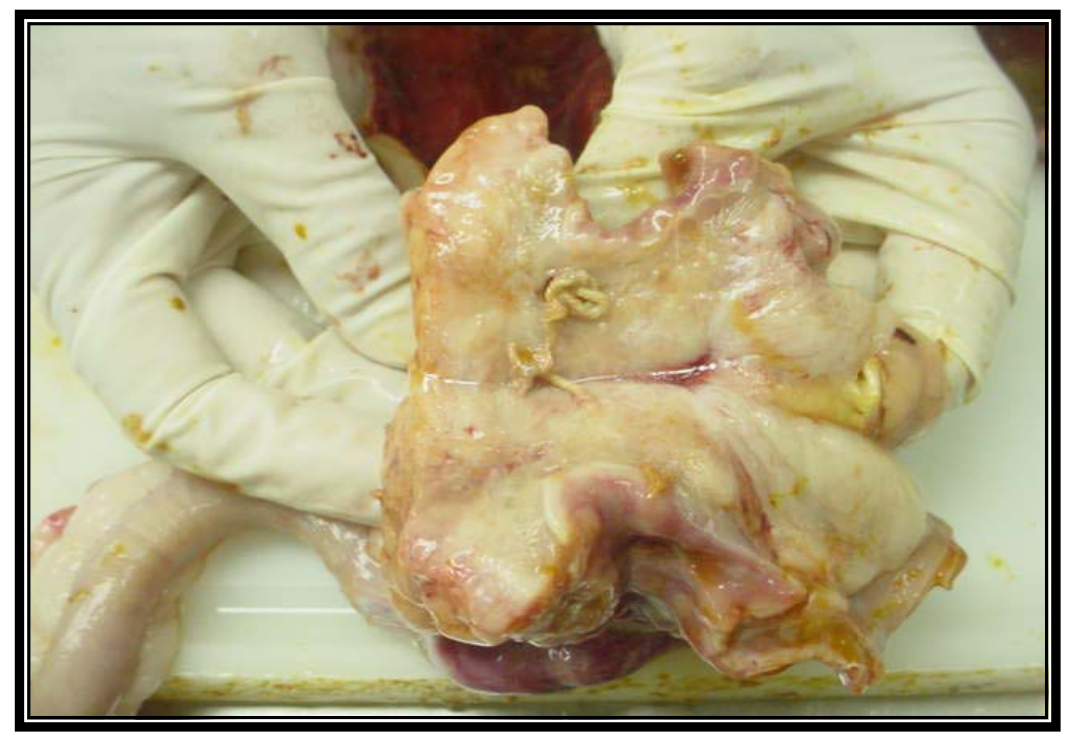

Figura 16: Aspecto macroscópico de lesão intestinal a fio de sutura não absorvível 


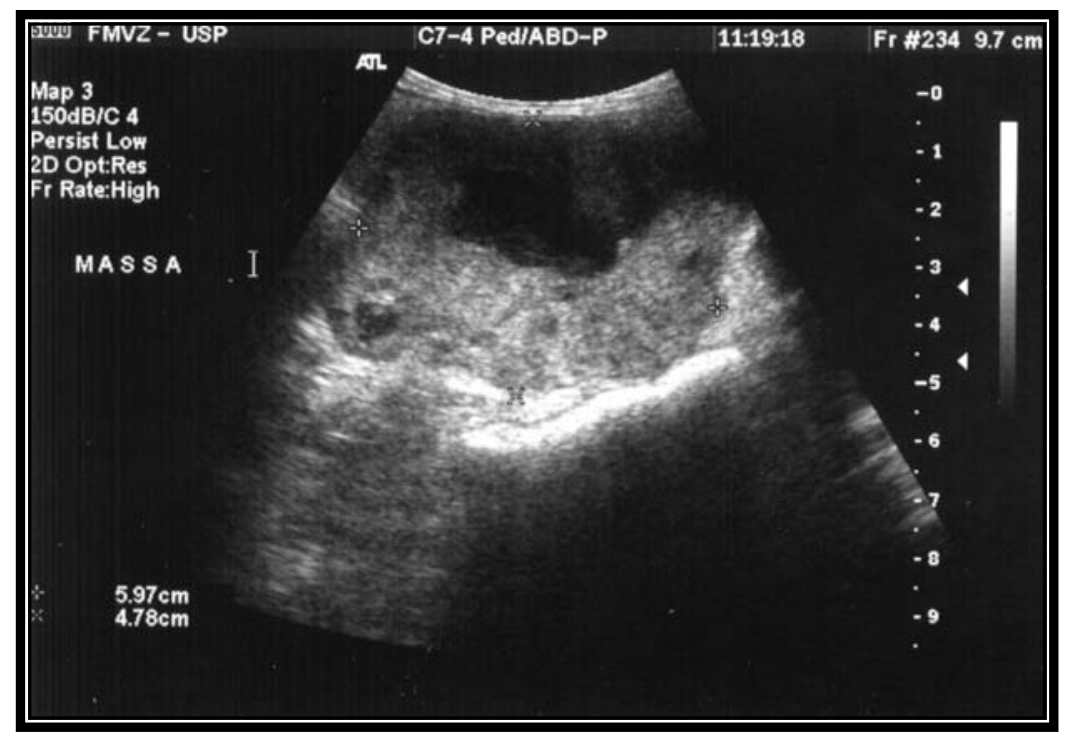

Figura 17: Imagem ultra-sonográfica de massa de ecogenicidade mista, apresentando áreas cavitárias e de contorno irregular. Adenocarcinoma pancreático

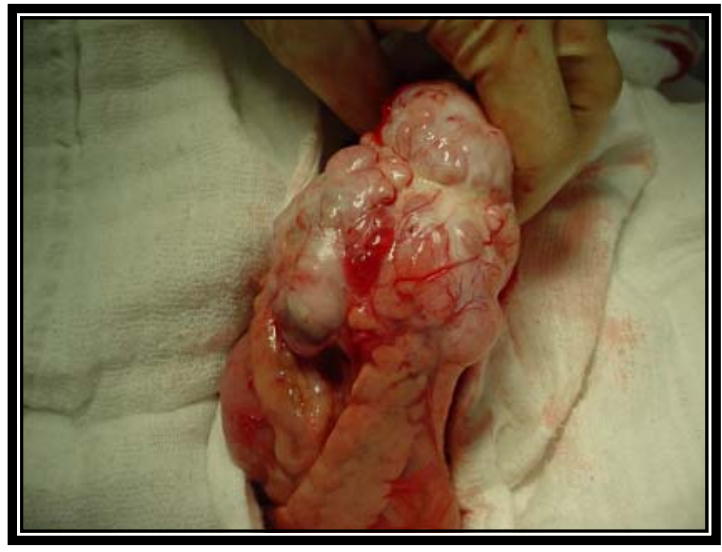

Figura 18: Aspecto macroscópico de Adenocarcinoma pancreático

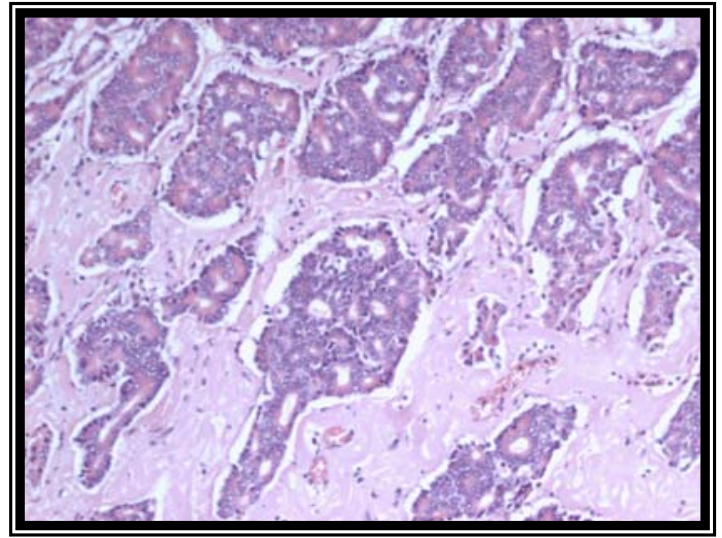

Figura 19: Foto micrografia Adenocarcinoma pancreático H\&E (10x) 


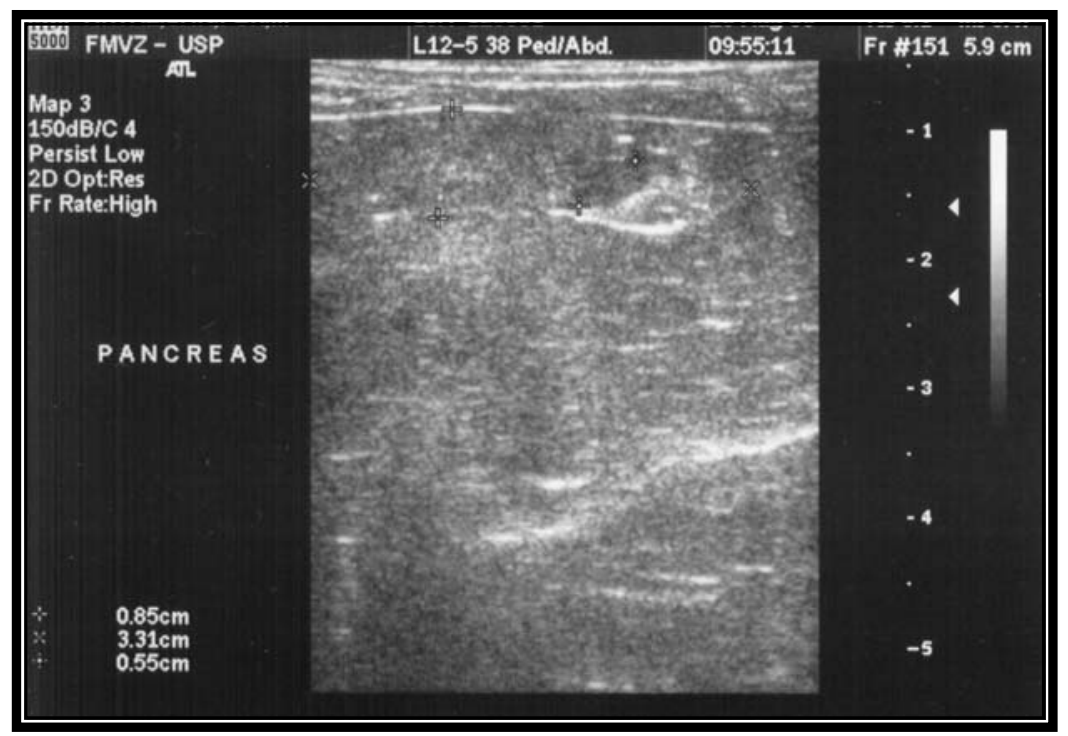

Figura 20: Imagem ultra-sonográfica de nódulo hipoecóico pancreático. Insulinoma

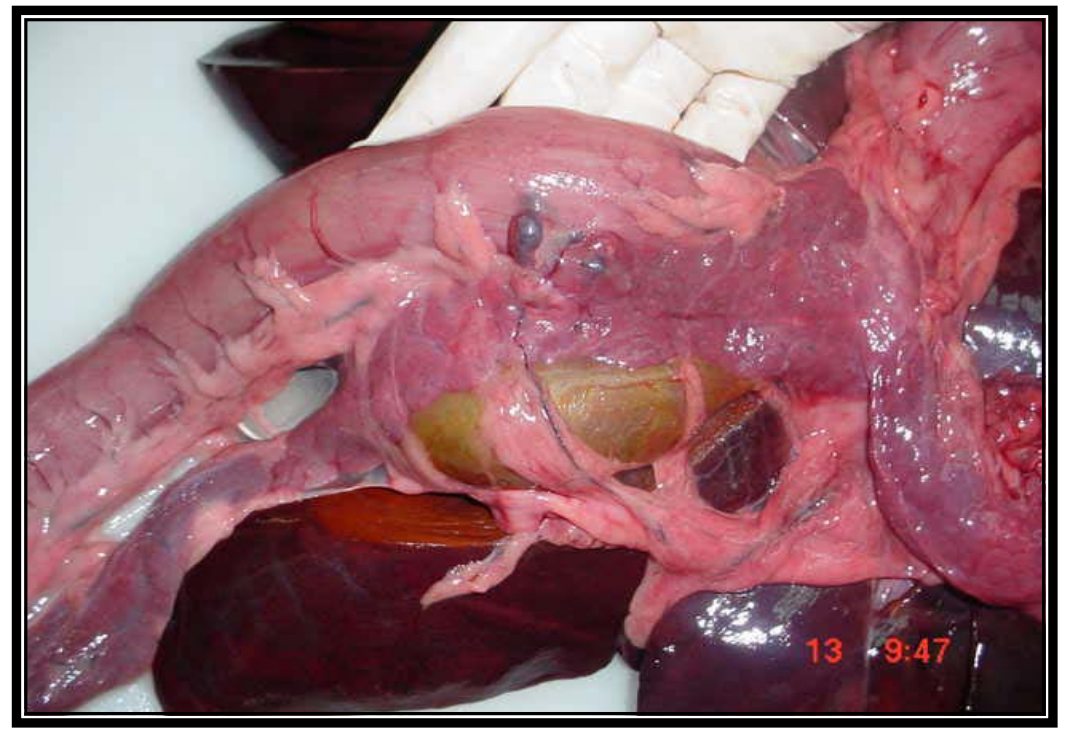

Figura 21: Aspecto macroscópico de insulinoma pancreático 
5 Discussão 


\section{DISCUSSÃO}

A melhora do atendimento médico veterinário e a crescente preocupação dos proprietários com relação à saúde de seus animais de companhia têm prolongado a vida destes últimos, o que aumenta a probabilidade de desenvolverem câncer. De acordo com estudos realizados por Bronson (1982), Craig (2001) e pela Morris Animal Foundation (1997), uma das principais causas de óbitos em animais de companhia idosos - cães e gatos - é o câncer.

Como anteriormente mencionado, as diferentes técnicas de diagnóstico por imagem são subsídios propedêuticos que auxiliam no diagnóstico de tumores abdominais (BLEVINS, 1998). Em função do baixo custo que apresenta em relação a outras modalidades de imagem mais avançadas - como a tomografia computadorizada e a ressonância nuclear magnética -, e da existência de aparelhos desse tipo em grande parte dos hospitais veterinários dos grandes centros, a utilização da ultra-sonografia vem se tornando prática comum em medicina veterinária nos últimos anos (HERRING, 1995).

Com base nesses fatores e na literatura consultada, os objetivos da presente investigação - que se constitui em um estudo prospectivo -, foram: determinar a acurácia do exame ultra-sonográfico na detecção da origem do órgão abdominal envolvido pelo processo neoplásico; determinar as características ultra-sonográficas dos diferentes tipos neoplásicos que acometem o fígado, os intestinos e o pâncreas; e avaliar a eficácia da ultra-sonografia bidimensional em apontar aspectos de malignidade nesses órgãos.

O presente estudo corrobora as postulações de Bragg (1985), para quem a ultra-sonografia não só colabora no diagnóstico como auxilia no estadiamento, na 
monitorização e na avaliação de possíveis complicações dos pacientes com tumores abdominais.

No entanto, esse método apresenta limitações decorrentes de sua característica intrínseca: como as imagens são realizadas e interpretadas em tempo real, o operador deve ter bons conhecimentos das propriedades físicas do som e dos diferentes tipos de artefatos (RESENDE, 1996; RODRIGUES et al.2002; SAUNDERS, 1998).

Em relação à casuística, 114 apresentavam-se dentro dos critérios de inclusão, sendo que $88(77,1 \%)$ efetivamente portavam neoplasias abdominais. 0 presente estudo não teve o objetivo de avaliar dados epidemiológicos dos processos neoplásicos abdominais e nem de compará-los com a literatura, de vez que não dispúnhamos de informações epidemiológicas dessa população.

Para manter os mesmos critérios de interpretação, todos os exames da presente investigação foram executados e interpretados por um único observador; examinadores múltiplos implicariam em um "bias" indesejado na avaliação da contribuição diagnóstica da ultra-sonografia.

O método sonográfico possibilitou 95,4\% (84 casos) de acerto, 3,5\% (3 casos) de erro e 1,1\% (1 caso) de indeterminação quanto ao órgão abdominal acometido pela massa (origem). Esses dados corroboram os achados de Blevins (2002), que comenta ser, a ultra-sonografia, um bom método para identificar o órgão afetado pelo tumor.

Os erros na classificação da origem da massa foram decorrentes de motivos mencionados por outros autores. Um desses erros pode ser atribuído à dificuldade de determinação da origem de massas muito grandes que tomam toda a cavidade abdominal (MILES, 1997). Assim, é necessário cautela quando da tentativa de 
determinar a origem de grandes massas abdominais, pois os órgãos envolvidos podem estar ocultos ou deslocados pela massa.

Em outro caso, o erro na detecção da origem da massa possivelmente se deu porque, como menciona Nyland (2002b), o pâncreas do cão é um órgão difícil de ser identificado ao exame ultra-sonográfico quando na ausência de alterações. Além disso, no animal em questão o órgão estava localizado na região hipogástrica - o que não é habitual -, e apresentava aparência semelhante a abscedação de linfonodo mesentérico.

O ovário também é um órgão de difícil identificação ao exame ultrasonográfico quando normal; todavia, a presença de cistos ovarianos quando presentes é facilmente identificada devido à sua localização caudo-lateral aos rins. Em um dos casos desta investigação, a presença de cistos ovarianos em um dos ovários, o aumento de útero, a presença de efusão peritoneal, a localização e a característica sonográfica da massa (perifericamente cística) contribuíram para a má interpretação e classificação de uma massa intestinal como massa ovariana. $\mathrm{Na}$ literatura consultada não há menção a dificuldades dessa ordem na determinação da origem da massa abdominal pelo exame ultra-sonográfico.

No animal em que não foi possível determinar ultra-sonograficamente a origem da massa, a cirurgia/necropsia revelou ser esta de origem esplênica. A porção esplênica vista ao exame sonográfico apresentava-se dentro dos critérios de normalidade; o animal ainda apresentava grande distensão gástrica gasosa e efusão peritoneal; a massa focal, cavitária e localizada na cabeça do baço não foi identificada ao exame ultra-sonográfico; a lesão encontrava-se em região epimesogástrica quase intercostal e, durante o exame, uma grande interferência gasosa estomacal foi visualizada. Essas dificuldades, que influenciaram no 
diagnóstico falso-negativo, provavelmente teriam sido minimizadas com a simples alteração no decúbito, um acesso intercostal do transdutor ou o melhor preparo do animal. Ressalte-se que um exame sonográfico cuidadoso e manobras não habituais devem ser realizados em animais com hemoperitônio e/ou com suspeita clínica ou radiográfica de massa; até mesmo o simples aumento da área de tricotomia do animal pode influenciar na detecção da lesão. Cabe ao ultra-sonografista a decisão de promover ou não essas manobras, incluindo a realização de um exame controle em outro momento, mais adequado, com o objetivo de melhorar a acurácia da técnica e evitar resultados indesejados.

\subsection{ORIGEM HEPÁTICA}

Como mencionado na Revisão da Literatura, os tumores abdominais podem ser primários ou metastáticos. Enquanto os tumores primários habitualmente afetam locais únicos, as metástases podem se estender para diferentes regiões da cavidade abdominal (BLEVINS, 2002). As neoplasias hepáticas, que se inscrevem entre as neoplasias abdominais, respondem por cerca de 0,6 a $1,3 \%$ de todas as neoplasias (PATNAIK et al., 1980).

Os tumores hepáticos primários são incomuns em cães, e podem ser de origem epitelial ou mesenquimal, benignos ou malignos. $O$ tumor benigno dos hepatócitos é denominado adenoma hepatocelular (ou hepatoma), enquanto o tumor maligno epitelial é denominado carcinoma hepatocelular. O carcinoma hepatocelular é a neoplasia maligna primária hepática mais comum em cães (HAMMER; SIKKEMA, 1995; PAITNAIK et al, 1980; STRAW, 1996). Em relação às neoplasias 
linfóides que acometem o fígado, o linfoma é predominante em animais da espécie felina e, embora se acredite que a mesma prevalência ocorra em cães, nem sempre o parênquima hepático de cães com linfoma é biopsiado (HAMMER; SIKKEMA, 1995).

Os tumores originados nos ductos biliares são denominados cistoadenomas biliares quando benignos, e colangiocarcinomas quando malignos. $O$ colangiocarcinoma pode ser intra-hepático, extra-hepático ou da vesícula biliar (JOHNSON, 2000).

Os tumores hepáticos primários de origem mesenquimal (sarcomas) são incomuns, enquanto o hemangiossarcoma e o leiomiossarcoma têm sido descritos com maior freqüência (STRAW, 1996).

No presente trabalho, foram estudados 15 cães a respeito dos quais foi aventada suspeita de processo neoplásico hepático; desses, 12 realmente estavam relacionados a tumor hepático. Dos 12 casos de tumores hepáticos diagnosticados, 11 eram neoplasias malignas e somente um caso revelou-se como neoplasia benigna.

Os tipos cito-histológicos diagnosticados foram: colangiocarcinoma 6(50\%); carcinoma hepatocelular 3(25\%); tumor de células mesenquimaishemangiossarcoma 1(8,3\%); linfoma de pequenas células 1(8,3\%); e cistoadenoma de vias biliares $1(8,3 \%)$. Essa casuística difere um pouco dos achados de autores como Hammer, Sikemma (1995); Paitnaik et al. (1980) e Straw (1996), uma vez que os colangiocarcinomas apresentaram maior prevalência que os carcinomas hepatocelulares. Entretanto, como não dispúnhamos de dados epidemiológicos hospitalares no período do estudo, a interpretação adequada desses valores e suas diferenças não puderam ser levadas a efeito. 
Os pacientes com neoplasias hepáticas apresentaram a seguinte distribuição: $8(66,6 \%)$ machos e $4(33,4 \%)$ fêmeas, $5(41,6 \%)$ cães SRD e $7(58,4 \%)$ cães CRD, com faixa etária entre 3 e 16 anos e mediana igual a 10,5 anos. Tais achados estão em consonância com a literatura consultada, que aponta prevalência de tumores hepáticos em cães machos com idade superior a 10 anos.

Hammer e Sikkema (1995) e Johnson (2000) comentam que os sinais clínicos em cães com neoplasia hepática são, na maioria das vezes, vagos e inespecíficos; os sinais de disfunção hepática normalmente só aparecem quando o tumor já se encontra em estágio avançado. Assim ocorreu nesta pesquisa, na qual os sinais clínicos dos animais com neoplasia hepática também foram pouco específicos, como: anorexia (8), massa hepática ou hepatomegalia à palpação (7), icterícia (5), perda de peso (5), distensão abdominal fluida (4), prostração (3), diarréia (2) e dispnéia (2).

Ruptura do tumor e hemorragia são mais freqüentes nos casos de adenoma hepatocelular, carcinoma hepatocelular e hemangiossarcoma hepático. Anemia e mucosas pálidas podem ser atribuídas à doença crônica hepática ou ruptura da neoplasia. A icterícia é incomum em cães, a não ser que a massa comprima as vias biliares (HAMMER; SIKKEMA, 1995).

De acordo com Gonzalez (2002) - que constatou que 11 de 18 animais com afecções hepatobiliares investigados apresentavam massas hepáticas -, a síndrome abdome agudo aparentemente também está relacionada a quadros de neoplasias hepáticas no cão. Embora o clínico veterinário responsável não tenha observado associação com essa síndrome, nos animais portadores de neoplasias hepáticas aqui avaliados, sempre é importante considerar a possibilidade de massas hepáticas em sintomas relacionados a abdome agudo no cão. 
Johnson (2000) menciona que os achados laboratoriais também são pouco específicos, e podem indicar a presença de doença hepática e suas complicações (JOHNSON, 2000). Essa informação não foi avaliada no presente trabalho, pois a análise dos achados laboratoriais dos pacientes não fazia parte dos objetivos propostos.

À ultra-sonografia, o parênquima hepático do cão apresenta-se como um como um órgão uniforme, com nível médio de ecogenicidade, semelhante ou ligeiramente mais hiperecóico que o córtex renal; as veias hepáticas e portais interrompem a arquitetura uniforme do parênquima. A vesícula biliar é usualmente anecóica, oval, e localiza-se justamente na linha média direita a região xifoíde (NYLAND et al, 2002a).

Embora Barr (1992) e Goldshalk et al. (1988) tenham realizado estudos de mensuração hepática, na tentativa de padronizar o volume hepático em cães, a eficácia desses métodos de mensuração ainda é objeto de grande discordância. $\mathrm{Na}$ presente investigação, como sugerido por Nyland et al. (2002a), os pacientes foram classificados como portadores de hepatomegalia quando havia aumento da distância entre o diafragma e o estômago, extensão do lobo hepático para a porção ventral da cavidade abdominal e visualização das margens hepáticas arredondadas e/ou irregulares.

Os aspectos ultra-sonográficos da neoplasia são determinados pela homogeneidade de seu tipo celular, pela quantidade de vascularização, pela extensão da hemorragia ou necrose, pela presença de tecido fibroso e pela deposição de minerais (SAUNDERS, 1998).

Acredita-se que os tumores hepáticos primários e secundários apresentam manifestações ultra-sonográficas amplamente variáveis. Apesar desta sobreposição 
de achados, e embora a biópsia seja imprescindível para o diagnóstico definitivo do tipo neoplásico, a ultra-sonografia pode sugerir linhas gerais de orientação das lesões tumorais (NYLAND et al. 2002a).

Os casos de colangiocarcinoma foram os mais freqüentes na casuística do presente estudo (6), e os aspectos sonográficos observados nesses animais foram: parênquima aumentado de tamanho com contorno irregular (6), nódulos cavitários complexos - ou seja, com septações internas - associados a nódulos em "alvo" (5); parênquima hepático heterogêneo apresentando nódulos hiperecóicos e em "alvo" (1). Em todos os animais foram observados nódulos em "alvo" e linfonodomegalia regional. Tais achados diferem daqueles apresentados por Whiteley et al (1989), que encontraram, na maioria dos quatro casos relatados, nódulos multifocais hiperecóicos ou hipoecóicos entremeados pelo parênquima, e não mencionam lesões em "alvo"; em um dos cães desse mesmo estudo, foi observada massa solitária em um dos lobos, mas os autores não mencionam se esta apresentava lesão cavitária em seu interior.

O aspecto de lesões cavitárias - complexas e císticas - também foi descrito por Machado, Rosa e Cerri (2002) como uma das características sonográficas de colangiocarcinoma intra-hepático em humanos, embora não muito freqüente. As lesões associadas ao colangiocarcinoma intra-hepático no homem têm, de maneira geral (aproximadamente $75 \%$ dos casos), aspecto relativamente homogêneo com nódulos hipoecogênicos, isoecogênicos ou hipoecogênicos, podendo ou não apresentar dilatações de árvores biliares. Esses mesmos autores também citam que, ocasionalmente, são observados nódulos satélites à lesão maior, assim como verificado nesta pesquisa, na qual todos os animais que tinham colangiocarcinoma apresentavam nódulos satélites em conjunto com as lesões cavitárias. 
Nesta investigação, o achado mais relevante nos cães com colangiocarcinoma hepático foram as lesões cavitárias complexas; essas lesões apresentavam septações internas e uma parede ecogênica espessa e irregular, o que foi inteiramente comprovado ao exame anatomopatológico. Do exposto, fica evidente que estas alterações são altamente sugestivas de colangiocarcinoma hepático canino, mas novos estudos, que contemplem casuísticas maiores, devem ser empreendidos para confirmar ou não a importância desses achados ultrasonográficos para o diagnóstico de colangiocarcinoma hepático no cão.

Machado, Rosa e Cerri (2002) comentam que, no homem, os colangiocarcinomas hepáticos apresentam tendência à invasão de ramos portais, o que contribui para a atrofia do setor hepático por eles suprido, determinando retrações na superfície do fígado. Os exames de imagem identificam sinais de invasão de ramos portais em $50 \%$ dos casos, seja pela evidenciação direta do comprometimento vascular - tumor no interior do vaso -, seja pelos sinais indiretos dessa invasão - como compressão vascular determinando irregularidades de contornos ou redução volumétrica do setor hepático a montante da lesão. No presente estudo não foram constatados sinais dessa ordem.

A literatura consultada não menciona a possível localização específica de metástases em cães com colangiocarcinoma. Nesta investigação, evidenciou-se a presença de metástases em linfonodos periportais em todos os animais (6), nódulos esplênicos (3), detecção de efusão peritoneal (3) e alteração em alças intestinais (2). As alterações ecográficas detectadas nesses casos foram confirmadas ao exame necroscópico. Tais achados demonstram a comunicação vascular da circulação hepatoesplênica e da drenagem portossistêmica, que provavelmente influenciam na disseminação metastática dos tumores hepáticos. 
Embora Whiteley et al. (1989) relatem que massas hiperecóicas e solitárias estão quase sempre associadas ao carcinoma hepatocelular, não se observou essa mesma característica sonográfica nos casos de carcinoma hepatocelular avaliados na presente pesquisa. Os achados ultra-sonográficos dos 3 casos de carcinoma hepatocelular aqui avaliados foram: parênquima aumentado de tamanho com contorno irregular (3), nódulos hiperecóicos mistos maiores associados a múltiplos nódulos em "alvo" (2) e nódulos hiperecóicos de contornos irregulares (1). Em todos os animais, o fígado tinha o padrão pavimentoso em mosaico. Foram observados linfonodomegalia regional (2) e nódulos em "alvo" no parênquima esplênico (1). O tamanho dos nódulos variou de 3,0 a $1,3 \mathrm{~cm}$.

Concorda-se com Fenney, Johnson e Hardy (1984), que postulam que lesões hipoecóicas focais ou multifocais não se relacionam a um tipo específico tumoral.

Em homens, o carcinoma pode aparecer como lesões focais de ecogenicidade variável, ou se apresentar como uma distorção difusa da arquitetura do parênquima sem identificação da massa - dependendo do tamanho e estágio. Esses aspectos ultra-sonográficos estão relacionados ao tipo macroscópico dos carcinomas hepatocelulares que, de acordo com Machado, Rosa e Cerri (2002) dividem-se em padrão nodular, em "massa" e difuso.

Além das formas de apresentação macroscópicas descritas, devem ser considerados os "pequenos" carcinomas, tumores menores ou iguais a $2 \mathrm{~cm}$. Os aspectos ultra-sonográficos dos "pequenos" carcinomas são variáveis, identificandose muitas vezes o aspecto em "mosaico", com formações de septos ecogênicos, halo periférico, sombra lateral - devido à pseudocápsula fibrosa -, e reforço acústico posterior - decorrente da diferença de textura entre o nódulo e o parênquima cirrótico adjacente (MACHADO; ROSA; CERRI, 2002). 
Também os carcinomas humanos maiores que $2 \mathrm{~cm}$ apresentam características ultra-sonográficas variadas: podem ter padrão mosaico e com aspecto heterogêneo, decorrente das mesmas alterações descritas para os "pequenos" carcinomas, ou seja, a apresentação ultra-sonográfica do carcinoma hepático no homem é variável: os maiores também podem assumir o aspecto de nódulos, com maior ecogenicidade e com configurações que se assemelham àquela de "olho de boi" ou em "alvo" - quando a periferia da lesão apresenta ecogenicidade diferente do centro. Assim como para os carcinomas "pequenos", esta diversidade decorre da variação da composição citoarquitetural (MACHADO; ROSA; CERRI, 2002).

Destaque-se que os trabalhos de medicina veterinária que contemplam os aspectos sonográficos do carcinoma hepatocelular em cães não mencionam os aspectos em "mosaico" e nódulos em "alvo" observados nesta pesquisa. Assim como nos carcinomas hepatocelulares dos homens, os achados sonográficos provavelmente estão correlacionados aos aspectos de variações da composição citoarquitetural dessa neoplasia, mas tais diferenças precisam ser melhor investigadas na medicina veterinária.

A presença de sinais de metástases regionais nestes casos de carcinoma também foi sugerida pelo exame ultra-sonográfico: foi evidenciado linfonodomegalia regional em 2 animais, e nódulos esplênicos em 1 animal.

O hemangiossarcoma hepático no cão pode ser classificado como primário quando acomete somente o fígado - ou multicêntrico. Whiteley et al. (1989) descrevem três casos que, a ecografia, revelaram nódulos multifocais hipoecóicos ou mistos, estes últimos classificados como hemangiossarcoma hepático multicêntrico. O acometimento hepático por hemangiossaroma primário foi pouco 
freqüente no presente trabalho: em um único caso avaliado, as características ultrasonográficas visualizadas foram além da hepatomegalia com contorno irregular, micronódulos multifocais irregulares, e nódulos hiperecóicos e hipoecóicos maiores, com diâmetro de aproximadamente 1,5cm. De acordo com Nyland et al. (2002a), os nódulos focais ou multifocais hipoecóicos não devem ser correlacionados a qualquer tipo histológico específico de tumor.

O linfoma hepático do cão é uma das neoplasias que apresentam maiores variações na imagem ultra-sonográfica: podem ser identificada lesões hiperecóicas focais ou multifocais, lesões hipoecóicas, em "alvo", e também aspectos infiltrativos como padrão difuso hipoecóico ou hiperecóico. Essa neoplasia hepática pode representar uma parte do envolvimento tumoral, ou seja, estaria relacionada ao linfoma multicêntrico (LAMB; HARTZBAND; TIDWELL, 1991; NYLAND et al., 2002a; PARTINGTON; BILLER, 1995).

Somente um caso de linfoma hepático de pequenas células sem envolvimento sistêmico foi observado nesta investigação. Os aspectos sonográficos visualizados nesse caso foram: hepatomegalia de contorno irregular, múltiplos nódulos hipoecóicos e em "alvo" distribuídos pelo parênquima, aspecto este mencionado por outros autores que também salientam que nódulos hipoecóicos e em "alvo" não devem ser relacionados a nenhum tipo específico tumoral (NYLAND et al. 2002a).

Não há, na literatura médico-veterinária, descrição das características ultrasonográficas específicas do cistoadenoma de vias biliares. No homem, os adenomas dos ductos biliares são lesões benignas e em geral assintomáticas, com localização usualmente subcapsular, e dimensões que variam de $1 \mathrm{~mm}$ a $1 \mathrm{~cm}$; o aspecto ultrasonográfico pode demosntrar múltiplas pequenas áreas de baixa ou alta ecogenicidade e, embora possam ser únicos ou múltiplos, apresentam-se como 
imagens sólidas hipoecogênicas, outras vezes hiperecogênicas ou em "alvo" (MACHADO; ROSA; CERRI, 2002).

No presente estudo, o animal que recebeu diagnóstico de cistoadenoma de vias biliares apresentou as seguintes características ultra-sonográficas: hepatomegalia de contorno arredondado e múltiplos nódulos hipoecóicos, aspecto este que, como anteriormente mencionado, não pode ser correlacionado a nenhum tipo tumoral específico.

A hiperplasia nodular hepática é considerada um dos principais diferenciais para a neoplasia em cães velhos com alterações sonográficas no parênquima. Esta enfermidade pode ocorrer em cerca de $70 \%$ dos cães idosos, mas as lesões freqüentemente não são identificadas ao exame de ultra-som. Habitualmente, a hiperplasia é benigna e não está relacionada a sintomas clínicos, mas os exames laboratoriais podem revelar leve a moderada alteração das enzimas hepáticas (JOHNSON, 2000; PRAUSE; TWEDT 2000).

Nenhum caso de hiperplasia nodular hepática foi observado neste estudo, provavelmente porque tais nódulos de hiperplasia, quando visíveis à ultrasonografia, são considerados "achados" sonográficos em exames de rotina em cães idosos, geralmente assintomáticos e descobertos de forma incidental. Na literatura consultada observa-se consenso com relação à relevância dessa enfermidade e, em concordância com os demais autores, pode-se dizer que o mais importante nessa doença é não confundi-la com o diagnóstico de neoplasia hepática quando os nódulos são identificáveis ao exame. Esses nódulos de hiperplasia podem ser únicos ou múltiplos, e normalmente são de ecogenicidade similar àquela do parênquima hepático, mas nódulos hiperecóicos ou de ecogenicidade mista - que normalmente apresentam contorno regular, e quase nunca alteram o tamanho, a 
forma e o contorno do órgão - também podem ser visualizados (JOHNSON, 2000; PRAUSE; TWEDT 2000).

Muito embora a biópsia hepática seja indicada, por vezes é difícil estabelecer, histologicamente, distinção entre hiperplasia, adenoma hepatocelular e carcinoma hepatocelular bem diferenciado (NYLAND et al., 2002a). De qualquer forma, a biópsia hepática é importante na tentativa de diferenciar a neoplasia hepática de outras doenças. Acredita-se que a principal dificuldade seja determinar o melhor período para realizá-la, se logo à detecção da alteração sonográfica ou após alguma mudança na imagem previamente diagnosticada em exames ultra-sonográficos anteriores.

Somente um trabalho de comprovação de parâmetros morfológicos ultrasonográficos em tumores abdominais hepáticos e esplênicos foi realizado em cães e gatos com o intuito de demonstrar seu valor indicativo para malignidade. Essa investigação retrospectiva, conduzida por Cuccovillo e Lamb (2002), estudou especificamente o valor indicativo de malignidade dos nódulos em "alvo" no fígado ou no baço de tais animais. A amostra era constituída por 20 cães e um gato que apresentavam nódulos em "alvo": ao exame histopatológico, 12 das 16 lesões em "alvo" hepáticas revelaram-se malignas, bem como cinco das sete lesões em "alvo" esplênicas. Nessa série, o achado ultra-sonográfico de uma ou mais lesões em "alvo" no fígado ou no baço teve um valor indicativo para malignidade de $74 \%$; quando verificadas múltiplas lesões de aspecto em "alvo" em um órgão, o valor indicativo para malignidade foi de $81 \%$. Os quadros benignos correlacionados a esse aspecto foram: hiperplasia nodular do fígado ou do baço, hepatite piogranulomatosa, cirrose e hepatite ativa crônica. 
O potencial de diagnóstico histopatológico incorreto relacionado às imagens das lesões focais em "alvo" da mencionada investigação, e o pequeno número de animais estudados, dificultaram o estabelecimento do real valor indicativo para malignidade de tais lesões, fazendo com que os autores concluíssem que nódulos em "alvo" não fornecem um diagnóstico específico, apesar de seu alto valor indicativo para malignidade (CUCCOVILLO; LAMB, 2002).

No presente estudo, os critérios morfológicos empregados na interpretação das imagens sonográficas para indicar malignidade fundamentaram-se na presença ou não de formações, características das lesões - focais ou multifocais -, suas variações de ecogenicidade e, principalmente, nas características de alteração de contorno, complexidade e presença de nódulos em "alvo", associados ou não à presença de alterações em outros órgãos, linfonodomegalia e efusão peritoneal.

De acordo com os critérios pré-estabelecidos para a diferenciação entre tumores hepáticos malignos e benignos, 11 (100\%) casos suspeitos de malignidade foram confirmados citologicamente ou anatomopatologicamente. Acredita-se que os mais relevantes indicativos de tumor maligno na ultra-sonografia bidimensional são: a complexidade da lesão, a alteração de contorno desta e/ou do órgão, associada a demais alterações abdominais, como presença de sinais de metástases - em baço, alças intestinais e linfonodos mesentéricos periportais -, ou a detecção de efusão peritoneal.

Parâmetros suspeitos para malignidade também foram observados em um caso de tumor benigno: cistoadenoma de vias biliares. Desta forma, e apesar da pequena incidência de tumores benignos, aparentemente houve tendência do método em diagnosticar malignidade. Diferentes achados sonográficos confundiram a interpretação neste caso: além dos achados do parênquima hepático, a presença 
de efusão peritoneal e a linfonodomegalia periportal foram os aspectos que mais dificultaram a classificação.

Os nódulos em "alvo" não foram interpretados como achados únicos na diferenciação entre tumores malignos e benignos, como na pesquisa de Cuccovillo e Lamb (2002). De qualquer forma, embora os tumores hepáticos não apresentem achados típicos ao ultra-som, tais nódulos, em conjunto com outras alterações, são um forte indício para malignidade.

A dimensão das lesões não foi utilizada como critério de diferenciação entre tumores malignos e benignos, semelhante à pesquisa de BENACERRAF et al. (1990). Isto porque o tamanho das lesões, na verdade, está relacionado à predominância dos componentes sólidos e císticos, sendo portanto dependente da intensidade dos fenômenos de hemorragia e degeneração.

Em três animais da amostra avaliada neste trabalho, o exame ultrasonográfico permitiu descartar a suspeita de neoplasia referida pelo clínico responsável: os diagnósticos desses casos foram hepatopatia crônica - fibrose hepática -, cirrose hepática e hepatomegalia por congestão. As características sonográficas observadas nesses três cães subsidiaram a exclusão de câncer hepático, em consonância com a descrição de Nyland et al. (2002a).

Por fim, admite-se que o papel da ultra-sonografia bidimensional hepática é a detecção ou a exclusão de lesões suspeitas de neoplasias, a avaliação da complexidade dessas lesões quando presentes e a avaliação dos outros órgãos da cavidade - de forma a inferir acerca da agressividade da moléstia -, permitindo planejar adequadamente a conduta a ser adotada frente ao quadro clínico do paciente. Considerando-se os objetivos propostos neste trabalho, a ultra-sonografia bidimensional hepática revelou-se um bom método para a investigação de suspeita 
de neoplasias do parênquima hepático e, em conjunto com os sinais de agressividade, auxiliou na determinação de malignidade.

Graças à sua importância no crescimento dos processos neoplásicos e à sua capacidade de invadi-los, a vascularização dos tumores foi extensivamente estudada (BONILA-MUSOLES et al.,1992; FOLKMAN et al., 1971; FOLKMAN, 1985; FOLKMAN, 1992; FOLKMAN e SHING, 1992 e SCHOR,SCHOR 1991). A ultrasonografia em efeito Doppler, em todas as suas formas, é um método particularmente promissor, não apenas pelo fato de não ser invasiva, mas também pela vantagem de prover informação dinâmica funcional com base anatômica. Vários estudos permitiram avaliar quantitativa e qualitativamente a vascularização dos tumores, e adquirem significativa relevância (MACHADO; ROSA; CERRI, 2002).

O mapeamento colorido permite identificar a presença de vascularização nas lesões previamente detectadas pelo exame bidimensional. Tanaka et al. (1992) procuraram diferenciar o carcinoma hepatocelular de outras massas focais com base no padrão do fluxo interno e circundante ao tumor. Tais autores sugerem que os padrões que apresentam fluxo em direção central ramificando para dentro do tumor e a presença de pontos coloridos ou remendos na região central do tumor, são características de carcinoma hepatocelular.

A utilidade do Doppler colorido, pulsado e em associação com contrastes ecográficos ainda está sendo pesquisada, e há muitas controvérsias quanto à sua real utilidade. Cerri, Mólnar e Vezozzo (1998) citam que o exame com Doppler colorido é um adjunto na rotina ultra-sonográfica, auxiliando na caracterização de massas malignas. 
Em trabalho publicado em 2003, Blanco et al. (2003) relatam o uso de contraste sonográfico foi capaz de identificar um grande número de vasos na totalidade dos tumores ovarianos da mulher, mas não melhorou a capacidade do Doppler na diferenciação entre tumores benignos ou malignos. Ou seja, muito embora a injeção de agentes produtores de microbolhas aumente a sensibilidade do método na diferenciação da natureza do tumor, este valor não se mostrou clinicamente útil na avaliação de tumores ovarianos.

Diferentes autores propuseram estudos com a técnica Doppler na avaliação do fluxo tumoral em cães (NYLAND et al. 2002a; SZATMÁRI; HARKANY; VÖRÖS, 2003). Entretanto, em medicina veterinária, até o momento, sabe-se que a identificação das estruturas vasculares permite minimizar os riscos de hemorragia no momento da biópsia ou durante o ato cirúrgico (BLEVINS, 2002).

O mapeamento com Doppler colorido e/ou Power Doppler foi realizado somente em três dos 12 casos de tumores no fígado da amostra aqui investigada, todos os três malignos. Devido à dificuldade de conter o animal na mesma posição durante o tempo necessário para a análise da lesão e à presença de gases no interior das vísceras ocas a avaliação foi bastante prejudicada, pois a técnica é extremamente sensível aos movimentos e artefatos gasosos, produzindo artefatos de "alising" que impossibilitaram a interpretação do exame. Talvez o jejum prévio, a utilização de drogas que diminuam o meteorismo intestinal e a contenção química pudessem facilitar a avaliação nos animais não cooperativos.

No caso de carcinoma hepático, o mapeamento colorido revelou a presença de vascularização central e periférica nos nódulos examinados, padrões de vascularização estes semelhantes àqueles descritos na literatura voltada ao assunto em humanos, que relata que os padrões sonográficos correspondem aos achados 
da anatomia patológica, demonstrando que tais lesões são bem vascularizadas (TANAKA et al, 1992; GONZÁLEZ-AÑÓN et al, 1999; MACHADO; ROSA; CERRI, 2002). Deve-se considerar que, embora revele de maneira bastante objetiva a vascularização dessas lesões, o mapeamento colorido apresenta semelhanças com padrões de outros tipos tumorais hepáticos malignos e benignos (GONZÁLEZ-AÑÓN et al, 1999).

Nos dois casos de colangiocarcinoma estudados pelo Doppler colorido, verificou-se presença de vascularização somente central (1) e central e periférica (1); neste último caso, a presença de fluxo sangüíneo também foi verificada na parede dos nódulos cavitários. Embora tais achados não sejam específicos dessa neoplasia, eles são semelhantes àqueles descritos por Harvey e Albrecht (2001) em humanos.

Assim como descrito por Tanaka et al. (1992), o mapeameamento colorido das lesões no parênquima hepático auxiliam na determinação de malignidade e, principalmente, na diferenciação de carcinoma hepatocelular hepático. Todavia, como a ausência de vascularização também pode ser vista nas neoplasias malignas, uma das grandes limitações da técnica Doppler é que os vasos muito pequenos e com fluxo muito baixo não são detectados. A utilização do Power Doppler e o uso de contrastes ecográficos aparentemente aumentariam a detecção da neoangiogenese tumoral, mas essas técnicas também aumentam a detecção de vasos tumorais em lesões benignas: assim, embora se aumente a sensibilidade do exame, a especificidade deste tende a diminuir (CERRI; MÓLNAR; VEZOZZO, 1998; BLANCO et al., 2003).

A associação entre os achados sonográficos e o mapeamento com o Doppler colorido - quando passível de realização -, e a correlação dos mesmos com o aspecto clínico do paciente podem auxiliar a determinar a malignidade do processo. 
Entretanto, o pequeno número de casos e a ausência de outras investigações em medicina veterinária a esse respeito, dificultam a real interpretação de tais resultados.

Em conformidade com outros autores, acredita-se que o mapeamento das lesões hepáticas com o Doppler colorido deve ser interpretado com cautela e sem dúvida em conjunto com as demais apresentações ultra-sonográficas bidimensionais e clínicas do paciente, nunca excluindo a necessidade de serem realizadas biópsias (CERRI; MÓLNAR; VEZOZZO, 1998; BLANCO et al., 2003).

\subsection{ORIGEM INTESTINAL}

Os tumores gastrintestinais representam cerca de $2 \%$ de todas as neoplasias em cães e gatos, e o segmento mais acometido é o intestino. Apesar da baixa incidência, estas neoplasias têm um grande impacto nos animais de companhia, já que, na maioria das vezes, o diagnóstico só é elucidado em estágios avançados da doença (MAGNE, 2000).

$\mathrm{Na}$ presente investigação, foram avaliados 12 cães objeto de suspeita de processo neoplásico intestinal. Destes, 8 casos realmente estavam relacionados a tumor intestinal. Dos 8 casos de tumores intestinais diagnosticados, 7 constuíam-se em neoplasias malignas, e somente um caso revelou-se como neoplasia benigna.

Os tipos cito-histológicos diagnosticados foram: adenocarcinoma 2 (25\%), linfoma $2(25 \%)$, leiomiossarcoma $2(25 \%)$, tumor de células mesenquimais 1 (12,5\%) e adenoma de cólon 1 (12,5\%). Aparentemente, essa casuística concorda com outros trabalhos constantes da literatura. 
Com relação ao sexo, à raça e à idade, os cães com neoplasias intestinais apresentaram a seguinte distribuição: 6 (75\%) eram fêmeas e 2 (25\%) eram machos; $2(25 \%)$ cães SRD e $6(75 \%)$ cães CRD, com faixa etária entre 6 a 14 anos e mediana igual a 8,5 anos. Contrariamente aos registros da literatura consultada, não foi evidenciada maior predisposição sexual para machos. Já com relação à faixa etária, os achados desta investigação assemelham-se àqueles relatados por outros autores (MAGNE, 2000). É necessário, entretanto, ressaltar que o delineamento do estudo, associado à não disponibilidade dos dados epidemiológicos hospitalares no período avaliado, dificulta a interpretação adequada desses valores e suas diferenças.

Normalmente, os cães com neoplasia gastroentérica apresentam uma história típica de disfunção crônica, com sinais clínicos como vômito, hematoemese, hematoquesia, melena, tenesmo ou disquesia, perda de peso e letargia. Algumas vezes, os cães apresentam sinais clínicos de característica aguda, mimetizando outros processos obstrutivos (MAGNE, 2000). A história e os sinais clínicos verificados nos cães com neoplasia intestinal deste estudo foram: hiporexia/anorexia (5); prostração, perda de peso (4); vômito e diarréia (3); vômito (2); aumento de volume abdominal (2); diarréia (1); disquesia e tenesmo (1); e dispnéia (1).

A ultra-sonografia abdominal é usualmente requerida em cães com suspeita de neoplasia gastrintestinal, permitindo muitas vezes eliminar diagnósticos diferenciais, principalmente com relação à doença inflamatória intestinal (HALL e SIMPSON, 2000; MAGNE, 2000).

Em condições favoráveis, é possível identificar ultra-sonograficamente todas as camadas parietais do trato gastrintestinal: a espessura parietal do intestino delgado em cães é de 2 a $4 \mathrm{~mm}$, a espessura da parede do duodeno é de cerca de 
$5 \mathrm{~mm}$ em raças grandes, $4 \mathrm{~mm}$ em raças médias e $3 \mathrm{~mm}$ em raças de pequeno porte (PENNINCK, 2002).

O duodeno proximal é visualizado na região crânio-ventral do abdome, adjacente ao rim direito e aos lobos hepáticos direitos; os demais segmentos do intestino delgado localizam-se na região média do abdome e, para o exame, o baço e a bexiga são utilizados como janela acústica. No cão, o ceco é de difícil localização porque, na maioria das vezes, está preenchido por gases (PENNINCK, 2002).

A principal limitação da ultra-sonografia das vísceras ocas é a presença de meteorismo - gases-, responsável por fenômenos de reverberação, cauda de cometa e sombreamento (PENNINCK; NYLAND; FISHER, 1989).

Assim como cita Penninck (1998), acredita-se que o exame ultra-sonográfico seja a modalidade de imagem mais eficiente e menos invasiva na detecção de tumores gastrintestinais em pequenos animais. Por intermédio desse exame, é possível avaliar as paredes gástrica e intestinal, classificar a extensão da lesão (focal, multifocal ou difusa), avaliar outros órgãos do abdômen na pesquisa de metástases e identificação de linfonodomegalias, e selecionar o método de biópsia mais adequado para o paciente em questão: ecodiridida, endoscópica ou cirúrgica (PENNINCK, 2002).

O adenocarcinoma gastrintestinal é uma neoplasia relativamente comum em animais da espécie canina, e atinge normalmente cães de meia idade a idosos. $\mathrm{O}$ tumor pode afetar qualquer segmento intestinal, e apresenta predisposição para a região do reto. Tipicamente, apresenta-se como uma infiltração local que pode causar constrição anelar e provocar quadro de estenose e eventual obstrução intestinal. 
Nos dois casos de adenocarcinoma intestinal avaliados neste trabalho, o exame ultra-sonográfico revelou espessamento parietal transmural assimétrico. Em um dos cães, esse espessamento localizava-se em dois pontos distintos, hipoecogênicos e de pequena extensão segmentar. No outro caso, o espessamento parietal tinha características ecogênicas e aspecto heterogêneo, sendo as lesões de grande extensão. Assim como mencionado por Ribeiro, Ventura e Barros (2002), esse tipo de alteração heterogênea acontece por causa das eventuais áreas anecóides do interior da parede, correspondendo a áreas de necrose.

Em ambos os casos, foi observada, além do espessamento parietal e perda de estratificação das camadas intestinais de aspecto anelar e constritivo, leve distensão fluida luminal indicativa de processo obstrutivo, achados iguais àqueles mencionados por Penninck (2002). Assim, e em concordância com esse autor, acredita-se que às vezes a lesão é tão grande que fica difícil acessar a sua extensão em comprimento, pois é maior que a face de leitura do transdutor.

Em um dos animais com adenocarcinoma, o exame ultra-sonográfico permitiu localizar o segmento intestinal acometido - região ileocecal -, embora essa região seja de difícil identificação sonográfica no cão (PENNINCK, 2002). Nesse caso, a identificação foi facilitada graças a fatores como acúmulo de fluido anterior ao segmento parietal alterado, em conjunto com severo espessamento da parede e às referencias anatômicas normalmente utilizadas para a localização deste segmento: região caudal de pólo renal direito.

A localização sonográfica do segmento de alça intestinal acometido é importante pois auxilia o cirurgião no planejamento operatório, alertando-o sobre as dimensões do tumor, as prováveis aderências nos órgãos adjacentes e o leito de segmentos vasculares importantes que possam estar comprometidos. Do exposto, 
fica evidente que um dos papéis fundamentais do ultra-sonografista - cujo exame deve ser meticuloso - é fornecer indícios dos locais da anatomia regional acometida, antecipando possíveis dificuldades táticas na cirurgia.

Nos casos de adenocarcinomas intestinais diagnosticados nesta investigação, a espessura parietal variou de 0,8 a $1,3 \mathrm{~cm}$. Outros achados ecográficos detectados na cavidade abdominal foram: esplenomegalia com nódulos hipoecóicos ou hiperecóicos (2) - esses podendo sugerir metástases -, linfonodomegalia mesentérica (2) e efusão peritoneal (1). Tais constatações reforçam o que postula Penninck (2002): quando na presença de alterações sugestivas de neoplasia intestinal deve-se realizar um exame atencioso de toda a cavidade abdominal, a fim de estabelecer diagnósticos diferenciais.

Apesar de não terem sido identificados neste estudo, os corpos estranhos intraluminais podem estar presentes na região intestinal proximal ao ponto de constrição da parede intestinal acometida pelo adenocarcinoma. A imagem hiperecóica com forte sombreamento acústico posterior é o achado mais evidente de corpos estranhos e de fácil caracterização. Todavia, essa imagem se sobrepõe àquela resultante da espessura da parede, provocando um falso negativo para tumor intestinal (GONZALEZ, 2002).

O linfoma quase sempre acomete os intestinos de animais da espécie canina, embora as formas extra-intestinais sejam mais comuns. As características clínicas observadas no linfoma são: perda de peso progressiva, diarréia e/ou vômito crônico; sinais extra-intestinais como linfonodomegalias podem ou não ocorrer (NELSON; COUTO, 1992).

Quase todos os trabalhos voltados às características sonográficas do linfoma do trato digestório foram realizados em felinos (GROOTERS et al., 1994). De 
qualquer maneira, Penninck (1998) comenta que os mesmos aspectos são visibilizados na espécie canina.

Nos cães que receberam diagnóstico de linfoma do trato digestório do presente estudo, os achados ultra-sonográficos foram distintos. Em um dos cães foi visualizado espessamento parietal focal, transmural, simétrico, demonstrando padrão em "alvo" ao corte transversal da alça, associado a linfonodomegalia mesentérica e esplenomegalia. No outro cão, foi verificada a característica infiltrativa do linfoma e espessamento difuso da parede em conjunto com linfonodomegalia mesentérica. Em ambos os cães houve perda de estratificação das camadas parietais, e o espessamento variou de 0,9 a $1,6 \mathrm{~cm}$. Como já relatado por Penninck (1998), existem diferentes aspectos sonográficos do linfoma do trato digestório no cão, sendo que o padrão difuso infiltrativo é o mais difícil de se diferenciar da doença inflamatória intestinal idiopática crônica.

$\mathrm{Na}$ medicina humana, a expressão tumores de estroma tem sido preferencialmente utilizada para designar a classe dos tumores mesenquimais benignos e malignos - da qual fazem parte o leiomioma, o leiomossarcoma e o lipoma. Esses tumores normalmente se originam da camada muscular própria da alça envolvida, sendo difícil a distinção entre benignos e malignos com base apenas nos aspectos macroscópicos e microscópicos da lesão, exceto quando a agressividade do tumor é caracterizada pela invasão local ou pela presença de metástases (RIBEIRO; VENTURA; BARROS, 2002).

O leiomiossarcoma intestinal foi diagnosticado em dois animais da presente investigação. As características ultra-sonográficas visualizadas nesses casos foram semelhantes àquelas descritas na literatura, como massas parietais extrínsecas, assimétricas e de ecogenicidade mista - áreas hipo/anecóicas centrais -, com 
tamanho variando de 3,5 a $4,5 \mathrm{~cm}$. Também perda de arquitetura das camadas foi visualizada em ambos os cães. A dificuldade de determinar a localização da massa e sua associação com segmentos intestinais é acentuada pela presença da imagem de gás intraluminal ou gás adjacente a esta, razão pela qual cuidados na identificação destes achados sonográficas e sua relação com a massa são importantes.

Em um dos casos desta série - leiomiossarcoma -, identificou-se a presença de linfonodomegalia mesentérica e nódulos mistos - hipoecóicos ou hiperecóicos no parênquima hepático, alterações também detectadas aos exames macroscópico cirúrgico e necroscópico. Tais achados são semelhantes àqueles descritos por Myer; Penninck (1994), e normalmente representam metástases abdominais, demonstrando a comunicação vascular da circulação portossitêmica que provavelmente influencia na disseminação metastática.

Em um animal, a neoplasia intestinal foi diagnosticada histologicamente como tumor de células mesenquimais; essa massa apresentava contornos assimétricos, ecogenicidade mista - com áreas anecóicas periféricas -, tendo sido erroneamente classificada como massa ovariana. Embora Myer e Penninck (1994) tenham sugerido que a presença de ar adjacente à massa facilita e assegura a identificação da origem intestinal desta, no caso ora mencionado essa identificação não foi possível. Provavelmente, a presença de outras alterações como identificação de aumento de corpo de útero, ovário policístico direito e ascite influenciaram no erro do diagnóstico, provando que a detecção de outras alterações sonográficas na cavidade abdominal do cão tanto pode facilitar como dificultar o diagnóstico. 
De qualquer maneira, as características ecográficas da massa são semelhantes àquelas descritas para tumores de estroma no homem: uma massa com crescimento extrínseco e extraluminal (RIBEIRO; VENTURA; BARROS, 2002).

Os adenomas colorretais são freqüentemente relacionados a sintomas de tenesmo e hematoquesia, que foram observados no único caso de adenoma colorretal deste estudo. Os pólipos adenomatosos retais são os tumores mais freqüentes e, diferentemente do homem, raramente ocorre transformação maligna desses pólipos.

Homco (1996) cita que o cólon pode ser identificado pela imagem em forma de "C" produzida pelo gás dorsalmente à bexiga urinária.

Embora o exame ultra-sonográfico não seja considerado técnica mais adequada na avaliação do intestino grosso devido ao conteúdo fecal e/ou gasoso acredita-se que um bom preparo do animal - por meio de jejum e lavagens intestinais -, associado à boa repleção da bexiga urinária, permite a realização de um bom exame da região do cólon de cães. Deve-se salientar que a sensível melhora na qualidade técnica dos equipamentos sonográficos e a presença de transdutores de alta freqüência têm proporcionado imagens diagnósticas em medicina humana, o que também poderá ocorrer na medicina veterinária.

As características ultra-sonográficas das neoplasias do intestino grosso de cães ainda não foram descritas. Em um cão com adenoma de cólon descendente avaliado no presente trabalho, o exame ultra-sonográfico revelou massas sólidas, ecogênicas, de contorno regular - aspecto de nódulos -, invadindo e causando estreitamento luminal. Havia uma transição abrupta do segmento normal e a região dos nódulos, visibiliou-se também perda parcial da estratificação das camadas parietais; o tamanho dos nódulos variou de 0,8 a $1,5 \mathrm{~cm}$. 
Neste animal, a identificação dos nódulos foi facilitada em virtude a fatores já mencionados, como a presença de pouco conteúdo fecal ou gasoso na região analisada, em conjunto com o bom preenchimento da bexiga urinária. Diferentemente do que sugere Penninck (2002), acredita-se que fezes uniformes e macias não podem ser confundidas com processos neoplásicos. Manobras compressivas com o transdutor, lavagens e/ou exames seriados após a defecação possibilitariam esta diferenciação quando na presença de imagens duvidosas. Entretanto, como a presente investigação contou com um único caso dessa ordem, sugere-se a realização de estudos com amostras maiores, que possam vir a confirmar a importância da ultra-sonografia nesse segmento intestinal e melhor definir suas indicações e limitações.

Nos quatro animais com suspeita de tumores intestinais cujo diagnóstico final não estava relacionado à neoplasia intestinal, os sinais clínicos foram: vômitos esporádicos com piora progressiva (2), vômitos e diarréia intermitentes (1) e diarréia com melena (1). Os diagnósticos foram: granuloma por fio de sutura não absorvível (2), enterite linfocítica-plasmocítica (1) e enterite eosinofílica (1). Assim como mencionado por Hall e Simpson (2000), verifica-se que os diferencias clínicos para tumores intestinais são os processos inflamatórios crônicos, já que a sintomatologia clínica de ambos é semelhante.

Parâmetros ultra-sonográficos como avaliação da espessura parietal intestinal, o comprimento da lesão e a integridade das camadas intestinal podem auxiliar nessa diferenciação, como postulam Lamb (1999) e Penninck (1998).

Nos dois casos de granuloma aqui observados, a ultra-sonografia revelou espessamento focal da alça intestinal, leve perda de estratificação de camadas e compressão extra-luminal. Em um dos casos a massa estava aderida à parede da 
alça de forma extramural, ecogênica e irregular. Os dois casos de granuloma apresentavam severa dilatação fluida no segmento intestinal anterior e peristaltismo não evolutivo. O espessamento parietal variou de 1,3 a 1,5cm. $O$ segmento de alça intestinal acometido em ambos os casos foi o duodeno descendente, caudomedial ao rim direito. Os achados sonográficos desses casos assemelham-se àqueles descritos por Coolman et al. (1999) e Lamb (2003), em que as cadelas também apresentavam processo obstrutivo intestinal, espessamento parietal focal significativo e perda de estratificação das camadas intestinais; a diferença encontrase somente na localização da lesão.

Nos animais do presente estudo, a região acometida pelo granuloma duodeno descendente - correlaciona-se com as referências anatômicas do ovário direito, provando que as alterações parietais focais nesse segmento intestinal devem ser interpretadas com cautela, e provavelmente em conjunto com a história clínica do animal -ovariossalpingo-histerectomia anterior -; aumentando assim a lista de diferenciais diagnósticos.

No caso de enterite eosinofílica, foram visualizados sonograficamente espessamento parietal multifocal, de ecogenicidade mista e com severa perda de estratificação das camadas da parede intestinal. Alguns segmentos apresentavamse dilatados por fluido, mas com peristaltismo evolutivo, à semelhança do que menciona Penninck (2003), para quem as enterites eosinofílicas apresentam lesões inflamatórias histologicamente severas, com áreas de hemorragia, necrose e formação de granulomas, dificultando muito a diferenciação sonográfica entre os processos neoplásicos.

Diferentemente, na enterite linfocítica-plasmocítica o espessamento parietal em geral é mais leve, normalmente de forma difusa e com a estratificação de 
camadas parietais preservadas, e dificilmente ocorre leve a moderada perda da estratificação da arquitetura da parede e/ou leve linfonodomegalia mesentérica (PENNINCK, 2003). No caso de enterite linfocitíca-plasmocítica constatado no presente estudo, verificaram-se exatamente as características sonográficas descritas pelo citado autor.

Avaliando a ultra-sonografia convencional na suspeita de tumores intestinais, e de acordo com os critérios pré-estabelecidos para a diferenciação de tumores e processos inflamatórios, dos 8 casos suspeitos de neoplasias intestinais $100 \%$ foram confirmados como tumores intestinais. Todavia, parâmetros suspeitos de processos neoplásicos também foram observados em três casos de enterite inflamatória granulomatosa, sendo dois por reação a fio de sutura não absorvível após ovariossalpingo-histerectomia e um de enterite eosinofílica, como citado anteriormente.

$\mathrm{Na}$ casuística avaliada observou-se que, semelhantemente ao relato de Penninck et al (2003), a perda de estratificação das camadas intestinais é uma excelente característica sonográfica na diferenciação entre estas duas enfermidades, com exceção dos casos de enterite eosinofílica e alguns tipos de enterites granulomatosas, em virtude da severidade histológica desses processos inflamatórios.

Com base nesses achados e em conformidade com Graham et al. (2000), Penninck et al. (2003) acredita-se que, embora a perda da arquitetura das camadas da parede intestinal seja um achado importante na diferenciação dos processos tumorais e inflamatórios, deve-se considerar o histórico do paciente, o potencial de diferenças geográficas e os "bias" epidemiológicos, como nos casos de processos inflamatórios causados pelo agente Pithium insidiosum. 
A avaliação pela técnica Doppler colorido e/ou Power Doppler foi realizada em quatro cães com lesões intestinais: um caso de adenocarcinoma, um caso de linfoma, um caso de adenoma em cólon e um caso de enterite eosinofílica. Em todos esses animais foi visualizada a presença de vascularização parietal central. Apesar do pequeno número de casos analisados, foi possível confirmar o que afirmam Ribeiro, Ventura e Barros (2002): não é possível diferenciar as lesões inflamatórias das neoplásicas por meio do mapeamento colorido ou power Doppler, visto que ambas cursam com o aumento de fluxo parietal.

Os outros cães com lesões intestinais não foram avaliados pelo Doppler colorido, basicamente devido à dificuldade de controlar os movimentos respiratórios e os movimentos do animal, e à presença de ar no interior das alças intestinais, ressaltando a dificuldade de adotar essa técnica em animais de companhia.

\section{ORIGEM PANCREÁTICA}

A maioria das neoplasias pancreáticas que acometem cães é de origem epitelial - o adenocarcinoma ductal ou acinar (WITHROW, 2001b). Essa neoplasia acomete animais de meia idade, e não apresenta predisposição sexual. Os sinais clínicos habitualmente são pouco específicos, e compreendem perda de peso, anorexia, depressão e vômito. Alguns cães podem apresentar icterícia em decorrência da possível obstrução das vias biliares ou das metástases hepáticas (BENNETT et al., 2001). Os sinais físicos, também inespecíficos, são: sensibilidade abdominal devido a pancreatite que pode ocorrer em concomitância e, 
ocasionalmente, massa abdominal cranial à palpação (BENNETT et al., 2001; WITHROW, 2001b).

No presente estudo, os processos neoplásicos pancreáticos foram confirmados em 4 dos 5 casos incluídos na amostra, todos eles malignos. A distribuição dos animais acometidos foi: 2 (50\%) machos e 2 (50\%) fêmeas, 2 (50\%) cães SRD e 2 (50\%) cães CRD, com faixa etária entre 7 a 15 anos e mediana igual a 11,5 anos.

Os sinais clínicos, similarmente ao que descreve a literatura, foram pouco específicos, como: anorexia (4), perda de peso (3), icterícia (1), distensão abdominal fluida (1) e dispnéia (1). A detecção de massa abdominal à palpação foi observada em dois casos, achado também mencionado por Bennett et al. (2001) e Withrow (2001b).

Os tipos diagnósticos cito-histológicos foram: neoplasia do pâncreas exócrino - adenocarcinoma pancreático - (3), neoplasia do pâncreas endócrino - insulinoma (1).

Os métodos de diagnóstico definitivo empregados foram: necroscópicohistopatológico 2(50\%), citológico 1 (25\%), cirúrgico-histopatológico 1 (25\%).

Os exames laboratoriais podem revelar aumento das enzimas pancreáticas, mas o aumento das enzimas hepáticas é mais evidente e está relacionado à presença de obstrução biliar extra-hepática. Embora o exame ultra-sonográfico e citológico do líquido ajudem a definir melhor as anormalidades pancreáticas, comumente o diagnóstico definitivo requer celiotomia exploratória, sendo imprescindível o exame histopatológico para a elucidação diagnóstica, já que ao exame macroscópico a pancreatite crônica e o carcinoma pancreático são semelhantes (WILLIANS, 2000). 
Ao exame ultra-sonográfico do abdome do cão o pâncreas, quando visível, é geralmente isoecóico a gordura abdominal adjacente, visibilizado como uma estrutura fina e hipoecóica dorsal ou dorsomedial ao duodeno, ventral a veia porta e caudal ao estômago (NYLAND et al., 2002b).

As características ultra-sonográficas detectadas nos casos de adenocarinoma pancreático foram: presença de massa com limites imprecisos em lobo pancreático direito (2); massas de ecogenicidade heterogênea, com áreas hipoecóicas e hiperecóicas (2); aumento de ambos os lobos pancreáticos associado à massa hipoecóica de contorno irregular em porção caudal de lobo direito (1). Em todos os casos a massa alterava a forma e a margem do órgão. Em um dos casos foi verificada a presença de 02 massas; não foi possível concluir com segurança a origem pancreática de uma dessas massas. De qualquer forma, o aspecto sonográfico dessa massa era semelhante ao descrito por Francisco Neto (2002) em medicina humana, com área central de liquefação representando necrose, de contornos irregulares, parede espessa e conteúdo heterogêneo.

O espectro dos achados ecográficos nos adenocarcinomas pancreáticos é amplo e, como já mencionado por Nyland et al. (2002b), muitas vezes não é possível estabelecer um diagnóstico diferencial entre os tumores pancreáticos, a pancreatite crônica ou os abscessos pancreáticos; principalmente se o exame foi realizado uma única vez pois, quando tratada de forma apropriada, é possível detectar a resolução da pancreatite nos exames controles.

Um dos aspectos que pode influenciar nessa diferenciação é o potencial de maliginidade do adenocarcinoma pancreático do cão, pois, usualmente, no momento do diagnóstico o paciente já apresenta sinais de metástases hepáticas, carcinomatose abdominal e hemoperitônio (NYLAND et al., 2002b). 
Nódulos hepáticos, espessamento e pregueamento duodenal, hemoperitônio e hiperecogenicidade mesentérica generalizada foram os achados ecográficos que auxiliaram na diferenciação entre adenocarcinoma pancreático e pancreatite em um dos quatro casos de abdome agudo estudado por Gonzalez (2002).

Além dessas características indiretas, também foram visualizados, na presente investigação, sinais de dilatação de ducto cístico, vias biliares intrahepáticas e colédoco associado a lítiase biliar (1); espessamento e plissamento duodenal (1); efusão abdominal e mesentério hiperecóico (3). É importante salientar que, mesmo com a detecção de todos esses aspectos sonográficos indiretos, não foi possível estabelecer a diferenciação entre os processos neoplásicos e inflamatórios pancreáticos, mesmo sabendo da invasão locorregional que o adenocarcinoma manifesta em alguns casos.

Sabe-se que nos processos inflamatórios graves do pâncreas esses achados podem estar presentes, mas só influenciariam na avaliação da gravidade do processo. A manifestação sonográfica mais eficiente nessa diferenciação provavelmente é a presença de nódulos hepáticos, já que linfonodomegalias peripancreáticas, mesentéricas, omentais e porto-hepáticas; mesentério hiperecóico e espessamento duodenal são freqüentemente visualizados em todos os processos pancreáticos.

Francisco Neto (2002) relata que, se o diâmetro do ducto de Wirsung ultrapassar a metade da espessura do parênquima pancreático do homem, a etiologia mais provável é a neoplasia, assim como a redução abrupta do calibre do ducto biliar, mas esses achados não foram avaliados nesta investigação.

Ainda com relação ao estadiamento do adenocarcinoma pancreático no homem, Francisco Neto (2002) menciona que uma avaliação minuciosa - incluindo 
tronco celíaco, artéria e veia mesentéricas superiores, veia porta e veia esplênica deve ser implementada. As estruturas vasculares podem ser melhor avaliadas com o uso do Doppler colorido (FRANCISCO NETO, 2002), que também influenciaria na identificação de carcinomas pancreáticos não ressecáveis (ISHIDA et al., 1999). Esse critério de investigação não foi incluído na presente investigação, mas a crescente sofisticação ultra-sonográfica e o aumento do conhecimento dos ultrasonografistas veterinários na avaliação pancreática tornam o Doppler colorido provavelmente um precioso instrumento na avaliação das estruturas vasculares peripancreáticas.

Em um cão com suspeita de neoplasia pancreática cujo diagnóstico final necroscópico-histológico foi de pancreatite crônica e abscesso pancreático, os sinais clínicos observados foram: vômitos esporádicos, hiporexia, febre e presença de massa detectada ao exame radiográfico. Os aspectos sonográficos visualizados nesse cão foram: presença de massa de contornos irregulares e de ecogenicidade severamente heterogênea, de aproximadamente $4,3 \times 5,8 \mathrm{~cm}$, em região de lobo pancreático direito. Em conjunto com essas alterações foram observados espessamento de bexiga crânio-ventral sugerindo cistite inflamatória-infecciosa, e pielectasia bilateral. Como discutido anteriormente, tais achados indicam que os aspectos sonográficos na região pancreática são muito semelhantes àqueles descritos nos casos de adenocarcinoma, exceto pela identificação de alterações em trato urinário, que poderiam sugerir um processo inflamatório infeccioso.

Ao analisar a ultra-sonografia modo bidimensional na suspeita de tumores pancreáticos exócrinos foi possível identificar a localização da massa pancreática; entretanto, não foi possível estabelecer diferenciação segura entre processo neoplásico e pancreatite crônica. Alguns sinais indiretos, como espessamento de 
duodeno, litíase biliar e sinais de processo obstrutivo biliar forneceram maior suspeita de processo neoplásico, mas não foram muito elucidativos.

Entre as neoplasias do pâncreas endócrino no cão, o insulinoma é o mais comum e normalmente maligno. Os sinais clínicos são convulsões, fraqueza ou desmaios decorrentes da hipoglicemia (DUNN et al., 1993), como verificado no único caso de insulinoma da amostra aqui estudada. Os sintomas causados pela hipoglicemia, em conjunto com a hiperinsulinemia orgânica, fornecem o diagnóstico não cirúrgico da neoplasia. O insulinoma pode se apresentar ultra-sonograficamente como: nódulos redondos ou lobulares, mas é muito difícil detectar esses nódulos no lobo pancreático esquerdo, pois a sensibilidade do ultra-som é muito baixa nesses casos (LAMB et al., 1995).

No caso de insulinoma avaliado nesta investigação, o exame ultra-sonográfico permitiu identificar o nódulo hipoecóico redondo, de aproximadamente $0,5 \mathrm{~cm}$ de diâmetro, localizado no lobo direito do pâncreas. Em concordância com Lamb et al. (1995) acredita-se que, quando os nódulos estão localizados no lobo direito do pâncreas, sua detecção é mais fácil, mas essa informação deve ser analisada com cautela, uma vez que um único caso foi avaliado neste estudo.

$\mathrm{Na}$ medicina humana, mesmo com as técnicas imaginológicas avançadas, aproximadamente 20 a $60 \%$ dos insulinomas não podem ser localizados em estudos pré-operatórios e, em 10 a $20 \%$ dos pacientes com insulinoma, a exploração cirúrgica falha em identificar e localizar o tumor. A ultra-sonografia intra-operatória tem mostrado resultados satisfatórios na localização de insulinomas pancreáticos, evitando ressecções desnecessárias (SILVEIRA et al., 2002), mas a utilização dessa técnica em animais ainda não foi objeto de pesquisa. 
A presente investigação comprova que a crescente sofisticação dos equipamentos de ultra-som e a introdução de transdutores de alta resolução promoveram sensível melhora na acuidade de detecção das alterações pancreáticas do cão. Entretanto, as ponderações de outros pesquisadores são pertinentes, já que a distinção entre pancreatites e processos neoplásicos muitas vezes não é possível. Além desta, outras limitações devem ser consideradas, como a presença de gás no interior das vísceras ocas e a dificuldade de avaliar minuciosamente o abdome de cães obesos ou que apresentem tensão abdominal decorrente de dor ou medo. 
6 Conclusão 
Pelos resultados obtidos neste trabalho, nas circunstâncias metodológicas em que o experimento foi delineado, pode-se concluir que:

O exame ultra-sonográfico bidimensinal foi eficiente na identificação do órgão abdominal acometido pela massa abdominal na maioria dos casos.

Nos casos de colangiocarcinoma hepático canino, os achados ultra-sonográficos mais relevantes foram lesões cavitárias complexas associadas a nódulos em "alvo".

Os aspectos ultra-sonográficos mais importante dos casos de carcinoma hepatocelular foram o padrão pavimentoso em "mosaico" e a presença de nódulos em "alvo".

De acordo com os critérios pré-estabelecidos o exame ultra-sonográfico bidimensional permitiu a diferenciação entre tumores hepáticos malignos e benignos na maioria dos casos.

A ultra-sonografia bidimensional foi eficaz no diagnóstico das neoplasias intestinais; a perda de estratificação de camadas parietais é um sinal importante na diferenciação entre neoplasias e enterites.

O exame ultra-sonográfico bidimensional não permitiu a diferenciação entre neoplasias pancreáticas e pancreatites. 
A associação dos achados sonográficos ao mapeamento com o Doppler colorido podem auxiliar a determinar a malignidade do processo. Entretanto, número limitado de casos e a ausência de outros estudos na medicina veterinária a este respeito, dificultam a interpretação destes resultados, abrindo-se assim, perspectivas para novos estudos na avaliação Doppler colorido, Doppler pulsado, Power Doppler e contrastes sonográficos nos tumores abdominais de cães. 


\section{Referências}




\section{REFERÊNCIAS}

ALMEIDA, M. R. P. Aspectos radiográficos e ultra-sonográficos das neoplasias abdominais em cães. 2002. 108f. Dissertação (Mestrado em Cirurgia) - Faculdade de Mdicina Veterinária e Zootecnia, Universidade de São Paulo, São Paulo, 2002.

ANDOF, E. Ultrasound screening in women at risk for ovarian cancer. Obstetric Gynecology, Hagestwon, v.36, p.423-32, 1993.

BARR, F. Ultrasonographic assessment of liver size in the dog. Journal of Small Animal Practice, Oxford, v. 33, n. 4, p. 359-364, 1992.

BAKER, R.; LUMSDEN, J. H. Color Atlas of cytology of the dog and cat. London: Mosby, 2000. p. 288

BLANCO, E.C. Doppler com emprego de contraste na diferenciação dos tumores ovarianos. 2000. $92 \mathrm{f}$. Tese (Doutorado) - Faculdade de Medicina, Universidade de São Paulo, São Paulo, 2000.

BLANCO, E. C.; PASTORE, A. R.; FONSECA, A. M; CARVALHO,F. M.; CARVALHO, J. P.; PINOTTI, J. A. Color Doppler sonography with contrast in the differentiation of ovarian tumors. Revista do Hospital das Clínicas, São Paulo, v. 58, n. 4, p. 185-192, 2003.

BLEVINS, W.E. Ultrasonography for cancer diagnosis and monitoring. In: MORRISON, W.B. Cancer in dogs and cats: medical and surgical management. 2.ed. Baltimore: Teton New Media, 2002. p.159-176.

BENNETT, P. F.; HAHN, K. A.; TOAL, R. L.; LEGENDRE, A. M. Ultrasonographic and cytopathological diagnosis of exocrine pancreatic carcinoma in the dog and cat. Journal of the American Animal Hospital Association. Denver, v. 37, n. 5, p. 466473, 2001.

BONILLA-MUSOLES, F. M.; BALLESTER, M. J.; CARRERA, J. M. Patologia del ovario. In: Doppler color transvaginal. Barcelona, Mason-Savat, 1992.

p. 99-109.

BOURNE, T.; WHITEHEAD, M. I.; CAMPBELL, S.; ROYSTIN, P.; BHAN, V.; COLLINS, W. P.; Ultrasound Screening for familial ovarian cancer. Gynecologic Oncology, New York, v. 43, n. 1, p. 92-97, 1991.

BRAGG, D. G. Imaging strategies for oncologic diagnosis and staging. In: BRAGG, D.G.; RUBIN,P.; YOUKER, J.E. Oncologic Imaging. Oxford: Pergamon Press, 1985. p. 13-21.

BRONSON, R. T. Variation in age at death of dogs of different sexes and breeds. American Journal of Veterinary Research, Chicago, v. 43, n. 11, p. 2057-2059, 1982. 
CERRI, G. G.; MÓLNAR, L. J.; VEZOZZO, D. C. P. Avaliação Dúplex do fígado, sistema portal e vasos viscerais. In: Doppler. São Paulo: Salvier, 1996. p. 91-128.

COOLMAN, B. R.; MARRETTA, S. M.; DUDLEY, M. B.;AVERILL, S. M. Partial colonic obstruction following ovariohysterectomy: a report of three cases. Journal of American Animal Hospital Association, Chicago, v. 35, n. 2, p. 169-172, 1999.

CRAIG, L. E. Cause of death in dogs according to breed: a necropsy survey of five breeds. Journal of the American Animal Hospital Association, Denver, v. 37, n. 5, p. 438-443, 2001.

CUCCOVILLO, A.; LAMB, C. R. Cellular features of sonographic target lesions of the liver and spleen in 21 dogs and a cat. Veterinary Radiology \& Ultrasound, Raleigh, v. 43, n. 3 , p. $275-278,2002$.

DUNN, J. K.; BOSTOCK, D. E.; HERRTAGE, M. E.; JACKSON, K. F.; WALKER, M. J. Insulin-sevreting tumours of the canine pancreas: Clinical and pathological features of 11 cases. Journal of Small Animal Practice, Oxford. v. 34, p. 325,1993

FERNANDEZ, M. P.; REDVANDLY, R. Primary hepatic malignant neoplasms. Radiologic Clinics of North America, Philadelphia, v. 36, p. 333-348, 1998.

FEENEY, D. A.; JOHNSTON, G. R.; HARDY, R. M. Two-dimensional, gray-scale ultrasonography for assessment of hepatic and splenic neoplasia in the dog and cat. Journal of the American Veterinary Medical Association, Chicago, v.184, n.1, p.68-81, 1984.

FOLKMAN, J. Tumor angiogenesis. Advances in Cancer Research, New York, v. 43, n. 2, p.175-203, 1985.

FOLKMAN, J. The role of angiogenesis in tumor growth. Seminars in Cancer Biology, Philadelphia, v. 3, n. 2, p. 65-71, 1992

FOLKMAN, J.; MERLER, E.; ABERNATHY, C.; WILLIAMS, G. Isolation of a tumor factor responsible or angiogenesis. The Journal of Experimental Medicine, New York, v. 133, n. 2, p. 275-288, 1971.

FOLKMAN, J.; SHING, Y. Angiogenesis. Journal of Biological Chemistry, v. 267, n. 6 , p. $10931-4,1992$

FOLKMAN, J.; WATSON, K. J.; INGBER, D.; HANAHAN, D. Induction of angiogenesis during transition from hyplerplasia to neoplasia. Nature, Basingstoke, v. 339, n. 4, p. 58-61, 1989. 
FRANCISCO NETO, M. J.; MACHADO, M. M.; OLIVEIRA, I. R. S.; CERRI, G. G. Pâncreas. In: CERRI, G. G.; OLIVEIRA, I. R. S. Ultra-sonografia abdominal. 2 ed. São Paulo: Revinter, 2002. p. 262-295.

FRYBACK, D. G.; THORNBURY, J. R. The fficacy of diagnostic imaging. Medical Decision Making, v.11, p.88-94, 1991.

GRAHAM, J. P.; NEWELL, S. M.; ROBERTS, G. D.; LESTER, N. V. Ultrasonography features of canine gastrointestinal pythiosis. Veterinary Radiology \& Ultrasound, Raleigh, v. 41, n. 3, p.273-277, 2000

GODSHALK, C. P.; BADERTSCHER, R. R.; RIPPY, M. K.; GHENT, A. W. Quantitative ultrasonic assessment of liver size in the dog. Veterinary Radiology, Raleigh, v. 26, n. 2, p. 162-167, 1988.

GONZÁLEZ-AÑON, M.; CERVERA-DEVAL, J.; GARCÍA-VILA, J.H.; BORDÓNFERRÉ, F.; AMBIT-CAPDEVILA, S.; PIQUERAS-OLMEDA, R.; JPRNETFAYOS, J.; GIL-SÁNCHES, S.; MARCO-DOMENCH, S. F.; CORTÉS-VIZCAÍNO,V. Characterization of solid liver lesions with color and pulsed Doppler imaging. Abdominal Imaging, New York, v. 24, n. 2, p. 137-143, 1999.

GONZALEZ, J.R.M. Emprego da ultra-sonografia ambulatorial na abordagem diagnóstica de cães com abdome agudo: Estudo de casos. 2002. 197f. Tese (Doutorado em Clínica Médica) - Faculdade de Medicina Veterinária e Zootecnia, Universidade de são Paulo, São Paulo, 2002

GROOTERS, A. M.; BILLER, D. S.; WARD, H.; MITYABASHI, T.; COUTO, G. Ultrasound appearance of feline alimentary lymphoma. Veterinary Radiology \& Ultrasound, Raleigh, v. 33, n. 3, p. 468-472, 1994.

HALL, E. J.; SIMPSON, K. W. Diseases of the small intestine. In: ETTINGER, S.J.; FELDMAN, E.C. Textbook of veterinary internal medicine diseases of the dog and cat. 5ed. Philadelphia:WB Saunders, 2000. v.2, p.1182-1237.

HAMMER, A. S.; SIKKEMA, D. A. Hepatic neoplasia in the dog and cat. The Veterinary Clinics of North America: Small Animal Practice, Philadelphia, v. 25, n. 2, p. 419-435, 1995.

HARVEY, C. J.; ALBRECHT, T. Ultrasound of focal liver lesions. European Radiology. v.11,n.9, 1578-1593, 2001. Disponível em: <http://link.springerny.com/link/servicejournals/00330/tocs.htm> Acesso em: 10 out. 2003

HERRING, D. S.; BJORNTON, G. Physics, facts and artifacts of diagnostic ultrasound. The Veterinary Clinics of North America: Small Animal Practice, Philadelphia, v. 15, n. 6, p. 1107, 1985.

HOMCO, L. D. Gastrointestinal tract. In: GREEN, R. W. Small animal ultrasound. Philadelphia: Lippincott-Raven, 1996. p.149-176. 
ISHIDA, H.; KONNO,K.; HAMASHIMA, Y.; NAGAMURA, H.; KOMATSUDA, T.; SATO, M.; ISHIDA, J.; MASAMUNE, O. Assessment of resectability of pancreatic carcinoma by color Doppler sonography. Abdominal Imaging, New York, v. 24, n. 3, p. 295-299, 1999.

JOHNSON, S. E. Chronic hepatic disorders. In: ETTINGER, S, J,; FELDMAN, E. C. Textbook of veterinary internal medicine diseases of the dog and cat. 5 ed. Philadelphia: W.B. Saunders, 2000. p.1298- 1325.

LAMB, C. R. Ultrasonography of the liver and biliary tract. Problems in Veterinary Medicine, Philadelphia, v.3, n.4, p.555-573, 1991.

LAMB, C. R. Recent developments in diagnostic imaging of gastrointestinal tract of the dog and cat. The veterinary clinics of North America: Small Animal Practice. Philadelphia, v. 29, n. 2, p. 307-342, 1999.

LAMB, C.R. What was your diagnosis?, Journal of small animal practice, Oxford, v.44, n.3, p.143-144, 2003.

LAMB, C. R.; HARTZBAND, L. E.; TIDWELL, A. S. Ultrasonography findings in hepatic and splenic lymphosarcoma in dogs and cats. Veterinary Radiology, Raleigh, v. 32, n. 3. p. 117-120, 1991

LAMB, C. R.; SIMPSON, K. W.; BOSWOOD, A.; MATTHEWMAN, L. A.

Ultrasonography of pancreatic neoplasia in the dog: a retrospective review of 16 cases. Veterinary Record, London, v.137, n.7, p.65-68, 1995.

LIN, Z.T.; WANG, L.Y.; WANG, J. H.; LU, S. N.; CHEN, S. C.; CHUANG, L. W; HSIEH, M.Y; TSAI, J. F; CHANG, W.Y . Clinical utility of color Doppler sonography in the differentiation of hepatocellular carcinoma from metastases and hemangioma. Journal of Ultrasound in Medicine, Philadelphia, v.16, n.1, p.51-58, 1997.

MACHADO, M. M.; ROSA, A. C. F.; CERRI, G. G. Tumores e lesões focais hepáticas. In: CERRI, G.G.; OLIVEIRA, I. R. S.; In: Ultra-sonografia abdominal. 2 ed. São Paulo: Revinter, 2002. p. 125-200.

MAGNE, L. M. Gastrointestinal neoplasia. In: KIRK, R. W.; BONAGURA, J. D. Kirk current veterinary XIII small animal practice. 13 ed. Philadelphia: W. B. Saunders, 2000. p.675-676.

MEUTEN, D. J. Tumors in domestic animals. 4. ed. Raleigh: lowa State Press, 2002. 788 p.

MILES, K. Imaging abdominal masses. The Veterinary Clinics of North America:

Small Animal Practice, Philadelphia, v. 27, n. 6, p.1403-1431, 1997. 
MORRIS ANIMAL FOUNDATION. Animal health survey. In: Companion animal news. Englewood, 1991.

MYERS III, N. C.; PENNINCK, D. G. Ultrasonographic diagnosis of gastrointestinal smooth muscle tumors in the dog. Veterinary Radiology \& Ultrasound, Raleigh, v. 35, n. 5, p. 391-397, 1994.

NELSON, R. W.; COUTO, C.G. Linfoma em cães e gatos. In: Fundamentos de medicina interna de pequenos animais, ed. Philadelphia:Mosby, 1992, p.634640.

NINO-MURCIA, M.; RALLS, P. W.; JEFFREY, R.B.; JOHNSON, M. Color flow Doppler characterizatio of focal hepatic lesions. American Journal of Roentgenology,Sprinfiled, v.159, n.12, p. 1195-1197, 1992.

NYLAND, T. G.; MATTOON, J. S.; HERRGESELL, E. J.; WISNER, E. R. Ultrasonography of the liver. In: NYLAND, T. G.; MATTOON, J. S. Small animal diagnostic ultrasound. 2 ed. Philadelphia: W. B. Saunders, 2002a. p. 93-127.

NYLAND, T. G.; MATTOON, J. S.; HERRGESSEL, E. J.; WISNER, E. R. Pancreas In: NYLAND, T. G.; MATTOON, J. S. Small animal diagnostic ultrasound. 2ed. Philadelphia: W. B Saunders, 2002b. p. 144-157.

PAITNAIK, A. K.; HURVITZ, A. C.; LIEBERMAN, P. H. Canine hepatic neoplasm: a clinicopathologic study. Veterinary Pathology, New York, v. 17, n.5, p.553-564, 1980.

PARTINGTON, B. P.; BILLER, D. S. Hepatic imaging with radiology and ultrasound. The Veterinary Clinics of North America. Small Animal Practice, Philadelphia, v. 25, n. 2, p. 305-335, 1995.

PENNINCK, D. G. Characterization of gastrointestinal tumors. The Veterinary Clinics of North America. Small Animal Practice, Philadelphia, v. 28, n. 4, p. 777796, 1998.

PENNINCK, D. G.Gastrointestinal tract. In: NYLAND, T. G.; MATTOON, J. S. Small animal diagnostic ultrasound. 2ed. Philadelphia: W. B. Saunders, 2002, p.207-230.

PENNINCK, D. G.; MOORE, A. S.; TIDWELL, A. S. MATZ, M. E.; FREDEN, G. O. Ultrasonography of alimentary lymphossarcoma in the cat. Veterinary Radiology \& Ultrasound. Raleigh, v. 35, n. 4, p. 199-204.

PENNINCK, D. G.; NYLAND, T. G.; FISHER, P. E. Ultrasonography of the normal canine gastrointestinal tract. Veterinary Radiology \& Ultrasound. Raleigh, v. 30, n. 6, p. 272-276, 1989.

PENNINCK, D. G.; SMYERS, B.; WEBSTER, C. R. L.; RAND, W.; MOORE, A. S. Diagnostic value of ultrasonography in differentiating enteritis from intestinal neoplasia in dogs. Veterinary Radiology \& Ultrasound, Raleigh, v. 44, n. 5, p. 570575, 2003. 
PFLUGER. T., CZEKALLA. R., HUNDT. C., SCHUBERT. M., GRAUBNER. U., LEINSINGER. G., SCHECK. R., HAHN. K. MR angiography versus color Doppler sonography in the evaluation of renal vessels and inferior vena cava in abdominal masses of pediatric patients. American Journal of Roentgenology, Springfiled, v. 173, n. 1, p. 103-108, 1999.

PHILLIPS, B. S. Tumors of the intestinal tract. In: WITHROW, S.J.; MacEWEN, E.G. Small animal clinical oncology. 3 ed. Philadelphia: W.B. Saunders, 2001. 335-346.

PRAUSE, L. C.; TWEDT, D. C. Hepatic nodular hyperplasia. In: KIRK, R.W.; BONAGURA, J.D. Kirk current veterinary XIII small animal practice. 13 ed. Philadelphia: W. B. Saunders, 2000. p.675-676.

RESENDE, C. M. C. Técnica e equipamentos. In: CERRI, G. G.; ROCHA,D. C. Ultra-sonografia abdominal: convencional, Doppler, técnicas endoscópicas, pediatria, intervenção. São Paulo: Salvier, 1996. p.15-30.

RIBEIRO, R. M.; VENTURA, C. A.; BARROS, N. Ultra-sonografia transabominal de vísceras ocas. In: CERRI, G.G.; OLIVEIRA, I. R. S. Ultra-sonografia abdominal. São Paulo: Revinter, 2002. p. 326-358.

RODRIGUES, M. B.; AMARO, E. Jr.; KODAIRA, S. K.; Anatomia ultra-sonográfica do abdome. In: CERRI, G.G.; OLIVEIRA, I. R. S.; Ultra-sonografia abdominal. 2 ed. São Paulo: Revinter, 2002. p.31-54.

SASSONE, A. M.; TIMOR-TRITSCH, I. E.; ARTNER, A.; WARREN, W. B. Transvaginal sonographic characterization of ovarian disease: Evaluation of a new scoring system to predict ovarian malignancy. Transvaginal Sonography, v. 78, n. 1, p. 70-76, 1991.

SAUNDERS, H. M. Ultrasonography of abdominal cavitary parenchymal lesions. The Veterinary Clinics of North America. small Animal Practices, Philadelphia, v. 28, n. 4, p. 755-797, 1998.

SCHOR, A. M.; SCHOR, S. L.; Tumour angiogenesis. The Journal of Pathology, London, v. 141, n.6, p. 385-413, 1991.

SILVEIRA, C.R.S.; HAUAGII, A.S.F.; WILTGEN, J.E.; BARRETO, C.M.; MIGUEL, G.S.P.; ROCHA, S.M.S.; GODOY, A.C. Ultra-sonografia intra-operatória na localização de insulinoma - relato de dois casos. Radiologia Brasileira, São Paulo, v. 5, n. 5, 2002.

STRAW, R.C. Hepatic tumors. In: WITHROW, S.J.; MacEWEN, E.G. Small Animal Clinical Oncology. 2. ed. Philadelphia: W. B. Saunders, 1996.p. 248-251. 
SZATMÁRI, V.; HARKÁNYI, Z.; VÖRÖS, K. A review of nonconventional ultrasound techniques and contrast-enhanced ultrasonography of noncardiac canine disorders. Veterinary Radiology \& Ultrasound, Raleigh, v. 44, n. 4, p.380-391, 2003.

TANAKA.S., KITAMURA.T, FUJITA. M.; NAKANISHI. K; OKUDA, S. Color Doppler flow imaging of liver tumors. American Journal of Roentgenology.Springfield, $v$. 154, n.4, p.501-514, 1990.

TANAKA.S.; KITAMRA.T.; FUJITA. M.; KASUGAI, H.; INOUE, A.; ISHIGORU, S. Small hepatocellular carcinomas: differentation from adenomatous hyperplastic nodule with color Doppler flow imaging. Radiology, Illinois, v.182 , n.1, p.161-165, 1992.

VÖRÖS, K.; VRABÉLY, T.; PAPP, L.; HORVÁTH, L.; KARSAI, F. Correlation of ultrasonographic and patho-morphological findings in canine hepatic diseases. Journal of Small Animal Practice, Oxford, v. 32, n. 12, p. 627-634, 1991.

WHITELEY, M. B.; FENNEY, D. A.; WHITELEY, L.O. Ultrasonographic appearance of primary and metastatic canine hepatic tumors: a review of 48 cases. Journal of the Ultrasound Medicine, Philadelphia, v. 8, p. 621-630, 1989.

WILLIANS. D. A. Exocrine pancreatic disease and pancreatites. In: ETTINGER, S.J.; FELDMAN, E.C. Textbook of veterinary internal medicine diseases of the dog and cat. 5ed. Philadelphia: WB. Saunders, v. 2, 2000, p.1345-1369.

WITHROW, S. J. Exocrine cancer of the pancreas. In: WITHROW, S. J.; MacEWEN, E. G. Small Animal Clinical Oncology, 3 ed, Philadelphia: W. B. Saunders, 2001. p. 521-523a.

WITHROW, S. J. Gastric cancer. In: WITHROW, S.J.; MacEWEN, E.G. Small Animal Clinical Oncology, 3 ed, Philadelphia: W. B. Saunders, 2001. p.323-327b. 